\title{
Revision of the Genus Polydora and Related Genera from the North West Pacific (Polychaeta : Spionidae)
}

\author{
AUTHOR(S):
}

Radashevsky, Vasily I.

\section{CITATION:}

Radashevsky, Vasily I.. Revision of the Genus Polydora and Related Genera from the North West Pacific (Polychaeta: Spionidae). PUBLICATIONS OF THE SETO MARINE BIOLOGICAL LABORATORY 1993, 36(1-2): 1-60

ISSUE DATE:

1993-03-30

URL:

http://hdl.handle.net/2433/176224

RIGHT: 


\title{
Revision of the Genus Polydora and Related Genera from the North West Pacific (Polychaeta: Spionidae)
}

\author{
VASILY I. RADASHEVSKY \\ Laboratory of Embryology, Institute of Marine Biology, Academy \\ of Scjences of Russia, Vladivostok 690041, Russia
}

With Text-figures $1-27$

\begin{abstract}
Fourteen species representing four genera Boccardiella, Neoboccardia, Polydora and Pseudopolydora of the polychaete family Spionidae from the North West Pacific are described on the basis of author's collections as well as material deposited in five museums. The study inclucles eight previously described species, two species raised in rank from subspecies, four new species, and six synonyms. Descriptions, figures and ecological data of the species covered, keys to the species of Polydora and Pseudopolydora from the North West Pacific, and diagnoses of the genera covered are included.
\end{abstract}

Key words: Polychaeta, Spionidae, Boccardiella, Neoboccardia, Polydora, Pseudopolydora, morphology, ecclogy, distribution

\section{Introduction}

About 30 polydorid species and subspecies are known to date from the north part of the West Pacific (Japan, the Sea of Japan, the Sea of Okhotsk, the Bering Sea, the Kurile Islands, and the Kommandor Islands). Our present knowledge of polydorids from the mainland coast of the Sea of Japan is based on the studies of Zachs (1933), Annenkova (1937, 1938), Buzhinskaja (1967, 1971), Bagaveeva (1981, 1986, 1988), Britayev \& Rzhavsky (1985), and Radashevsky (1983, 1985, 1986, 1988). These authors described or recorded 16 polydorid species. Twelve polydorids were described from Japan by Söderström (1920), Okuda (1937), Imajima \& Hartman (1964), Myohara (1979, 1980), Imajima \& Sato (1984), Mori et al. (1985), and Sato-Okoshi et al. (1990). Seven polydorid species were reported from Sakhalin by Uschakov (1950, 1953, 1959), Bagaveeva (1981, 1988), and Buzhinskaja (1985). The intertidal polychaetes of Shikotan Is. and from the South Kurile Islands were studied by Chlebovitsch (1959, 1961), Uschakov (1959), and Kussakin (1975, 1978). Seven polydorid species and subspecies were reported. From the Middle and the North Kurile Islands, only one intertidal polydorid species, Boccardia natrix (Söderström, 1920), was recorded by Chlebovitsch (1959, 1961), Tarakanova (1974, 1975), and Kussakin (1975). Eight Polydora species were reported from Kamchatka, the western part of the Bering Sea and the Bering Strait by Annenkova (1934, 1952), Uschakov (1950, 1953), Spassky (1961), Tarakanova (1978), and Rzhavsky \& Solokhina $(1988,1989)$. Key to polydorid species from the Far East Seas of the USSR was given by Uschakov $(1955,1965)$ and to those from Japan by Imajima \&

Publ. Seto Mar. Biol. Lab., 36(1/2), 1-60, 1993. (Article 1) 
Hartman (1964). The present study is an attempt to reevaluate older records on the basis of new information on the polydorid species from the north part of the West Pacific.

\section{Materials and Methods}

As a result of the author's location at a biological station "Vostok" of the Institute of Marine Biology, Academy of Sciences of Russia, situated on the shore of Vostok Bay, Peter the Great Bay, the Sea of Japan, extensive collections were made in that area. Field collections were also obtained during the cruises of the R/V "Berill" and the R/V "Lugovoye" both of the IMB: in August 1987, to Shikotan Is. and Habomai of the Small Kurile Archipelago (Suisio Sioto); in September 1987, to East Korean Bay; in October 1987, to Uspeniya Bay, Olga Bay, and Vladimir Bay (mainland

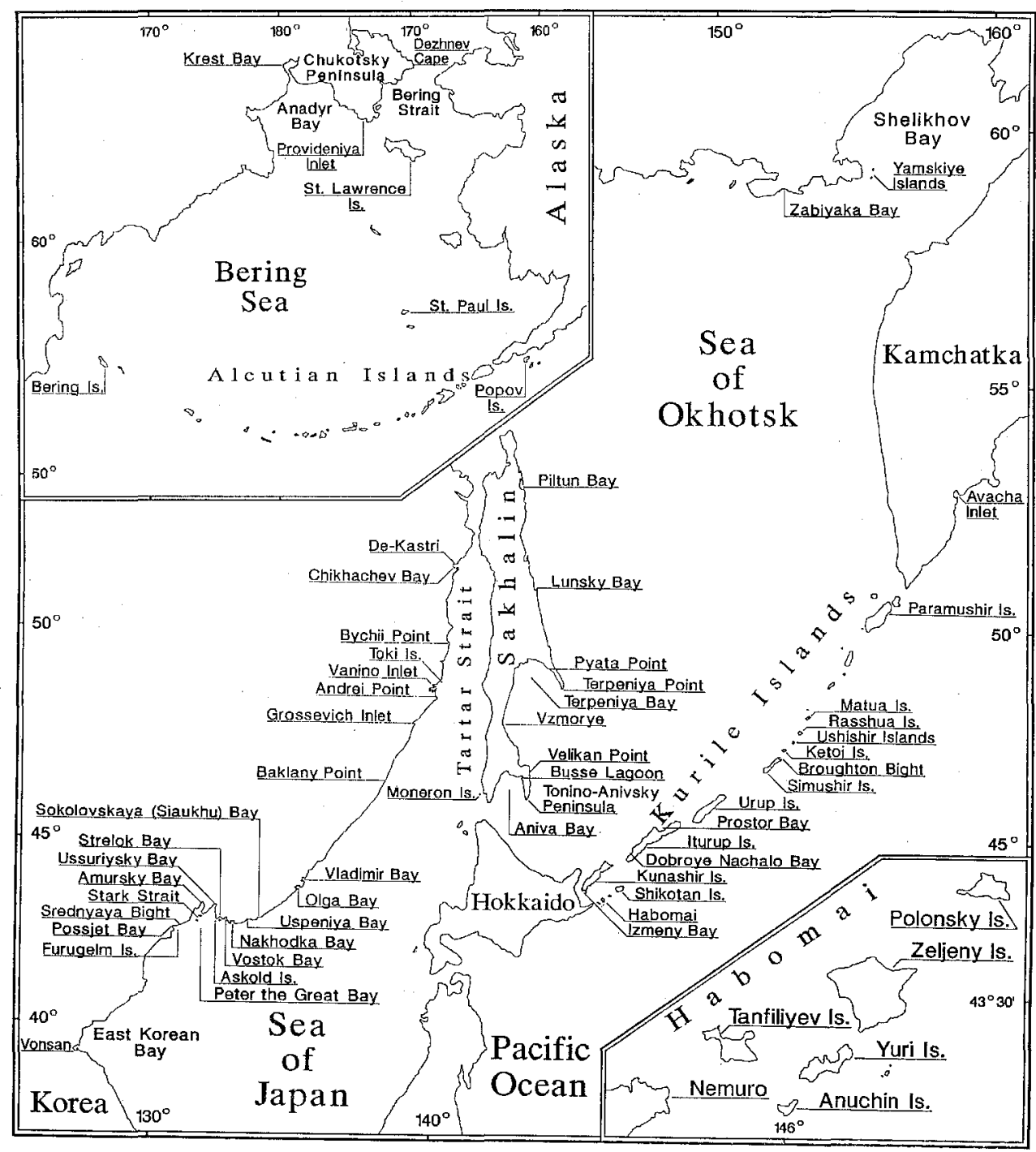

Fig. 1. Maps showing localities mentioned in the text. 
coast of the North Japan Sea); in June-July 1988, to Matua Is., Rasshua Is., Ushishir Islands, Ketoi Is., Simushir Is. of the Middle Kurile Islands and Iturup Is. of the South Kurile Islands; in June-July 1989, to the Small Kurile Archipelago, Iturup Is., Sakhalin Is., Moneron Is., and mainland coast of the North Japan Sea from De-Kastri, Chikhachev Bay south to Vladivostok, Peter the Great Bay; in June 1990, to East Korean Bay; in July 1990, to Sakhalin Is., Moneron Is., and mainland coast of the North Japan Sea from Chikhachev Bay south to Vladivostok. Some collections from Peter the Great Bay were made during the short cruises of the R/V "Professor Nassonov" of the IMB. Author's materials collected during the IMB Expeditions in September 1983 to Avacha Inlet of south-castern Kamchatka, and in August 1989 to Zabiyaka Bay and the Yamskiye Islands of the North Okhotsk Sea are also included. The collection localities mentioned in the text are shown in Fig. 1.

Polychaetes were collected in all regions intertidally and subtidally mainly to a depth of $40 \mathrm{~m}$ and occasionally to a depth of $100 \mathrm{~m}$. Subtidal samples to a depth of $40 \mathrm{~m}$ were obtained by the author with SCUBA. Deep-sea materials were obtained with a trawl. Numerous samples of sediment were studied to receive polychaetes inhabiting tubes. About 50 species of gastropods, about 50 species of bivalves, about 20 species of sponges, more than 10 species of tunicates, 5 species of barnacles, 3 species of brachiopods and numerous crusts of coralline algae were examined for symbiotic polydorids (borers and others).

The worms were relaxed in $3 \%$ magnesium chloride prior to examination. Width measurements given in the species descriptions refer to the first-branchial body width (at about setigers 6-10) measured with an eyepiece scale on a stereomicroscope. All descriptions and sketches were made using living relaxed material. Sketches were made using camera lucida. Descriptions include both external and some internal characters; the presence or absence of a gizzard-like structure and the position of glandular pouches. These structures can be easily determined on the unstained squash preparations of living worms or after dissection of the fixed material. The gizzard-like structure is a part of the digestive tract located between the esophagus and the intestine. Its function is unknown. The glandular pouches are gatherings of large glandular cells in the ventral part on both sides of a somite, inside the fixed segments. Older collections of spionids deposited in the Zoological Institute, Academy of Sciences of Russia, St. Petersburg (ZISP), in the Zoological Museum of the Moscow Lomonosov State University, Moscow (ZMMU), and in the Institute of Marine Biology, Academy of Sciences of Russia, Vladivostok (IMBV), were examined. Additional materials from Oki Islands of the Sea of Japan provided by Takumi Kato, Japan, from south-eatsern Kamchatka provided by Alexander Rzhavsky, Pacific Institute of Geography, Academy of Sciences of Russia, Petropavlovsk-Kamchatsky, and from western coast of North America kindly loaned both by Nora Foster, University of Alaska, Museum, Fairbanks (UAMF), and by Linda Ward, United States National Museum of Natural History, Smithsonian Institution, Washington D.C. (USNM), were also examined.

The type and representative materials of polydorids described below are deposited in ZISP, ZMMU, IMBV, USNM, and in National Science Museum, Natural History Institute, Tokyo (NSMT).

\section{Systematic Account}

The following polydorid species are covered in this report (synonyms in parentheses; * denotes new synonyms):

1. Boccardiella hamata (Webster, 1879)

(Boccardia uncata Berkeley, 1927)

2. Neoboccardia perata (Chlebovitsch, 1959)

3. Polydora commensalis Andrews, 1891

4. Polydora concharum Verrill, 1880

5. Polydora quadrilobata Jacobi, 1883

6. Polydora spongicola Berkeley et Berkeley, 1950

(*Polydora uschakovi Buzhinskaja, 1971)

7. Polydora cardalia E. Berkeley, 1927 
(*Polydora socialis plena Berkeley et Berkeley, 1936)

(*Polydora soederstroemi Annenkova, 1938)

8. Polydora brevipalpa Zachs, 1933, stat. $\mathrm{n}$.

(Polydora ciliata brevipalpa Zachs, 1933)

(*Polydora variegata Imajima et Sato, 1984)

9. Polydora bidentata Zachs, 1933, stat. n.

(Polydora flava bidentata Zachs, 1933)

(*Polydora ciliata possjetica Buzhinskaja, 1971)

(*Polydora convexa Blake et Woodwick, 1972)

10. Polydora trilobata sp. n.

11. Polydora alborectalis $\mathrm{sp} . \mathrm{n}$.

12. Polydora carunculata sp. $\mathrm{n}$.

13. Polydora glycymerica sp. $\mathrm{n}$.

14. Pseudopolydora paucibranchiata (Okuda, 1937)

(?Polydora (Carazzia) derjugini Zachs, 1933)

(Polydora (Carazzia) orientalis Annenkova, 1937)

The following polydorid species have been found by the author in the North West Pacific but they are not included in the present paper, because some difficulties in their systematics exist:

1. Polydora cf. caulleryi Mesnil, 1897

2. Polydora cf. ciliata (Johnston, 1838)

3. Polydora limicola Annenkova, 1934

4. Pseudopolydora kempi japonica Imajima et Hartman, 1964

\section{Genus Boccardiella Blake et Kudenov, 1978}

Type species: Boccardiella hamata (Webster, 1879)

Diagnosis: Prostomium narrow, anteriorly rounded or incised. Setiger 1 with or wtihout notosetae. Setiger 5 strongly modified with only one type of major spine in single row, with smaller companion setae. Neuropodial bidentate hooded hooks from setiger 7, curved or quite straight, without constriction on shaft. Branchiae from setiger 2 .

\section{Boccardiella hamata (Webster, 1879)}

(Figures 2 \& 3)

Polydora hamata Webster, 1879, pp. 251-252, pl. 8, figs 111-116, pl. 9, figs 117-118. --Hartman, 1944a, pp. 336-340; 1951, pp. 82-83; 1959, p. 384. --Rioja, 1960, pp. 304-306.

Boccardia uncata Berkeley, 1927, p. 418, figs 9-13. --Hartman, 1941, p. 304, pl. 48, fig. 46; 1944b, p. $260 ; 1954$, p. $9 ; 1959$, p. $375 ; 1961$, p. 168, pl. 15; 1969, pp. 103-104, figs 1-5. --Imajima \& Hartman, 1964, p. 281, See Blake, 1966.

Polydora (Boccardia) uncata: Okuda, 1937, pp. 238-240, figs 16-17. --Berkeley \& Berkeley, 1952, pp. 14-15, figs 18-21.

Boccardia hamata: Blake, 1966, pp. 177-182, figs 1-11, comb. nov.; 1969a, p. 814, fig. 1. --Blake \& 


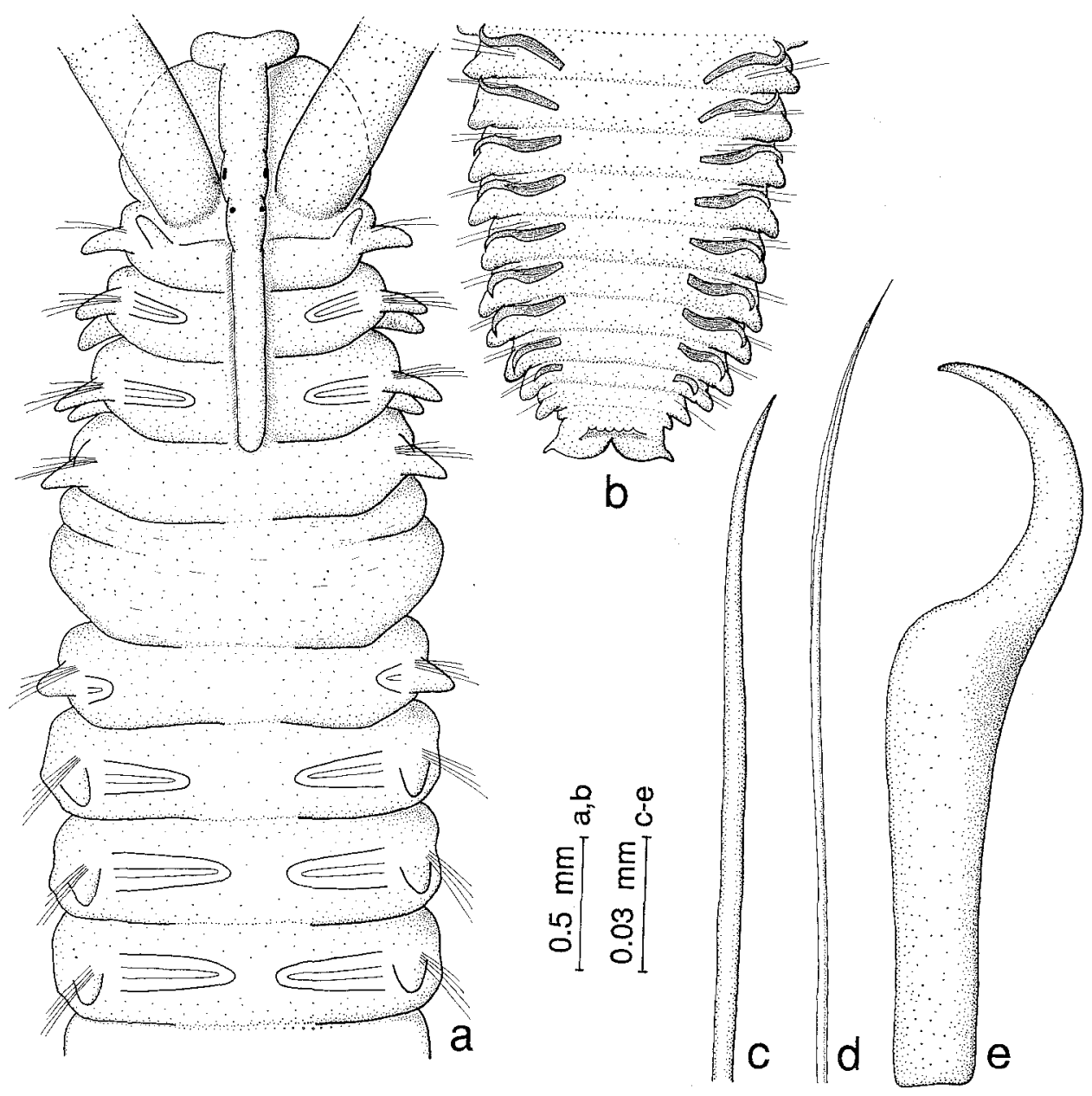

Fig. 2. Boccardiella hamata (Webster). a, anterior end, dorsal view; b, posterior end, dorsal view; c, posterior notopodial unwinged capillary; d, posterior notopodial winged capillary; e, posterior notopodial hook.

Evans, 1973, pp. 239-247.

Boccardiella hamata: Blake \& Kudenov, 1978, p. 265, comb. nov.

Material examined. Boccardiella hamata: ZISP 1/46591, Sea of Japan, Peter the Great Bay, Vityaz Inlet, $6 \mathrm{~m}$, from shell of scallop Mizuhopecten yessoensis, 1 spec., 12 April 1984, coll. V. Radashevsky; ZISP 2/46592, Sea of Japan, Peter the Great Bay, Possjet Bay, from coralline alga incrusting shell of mussel Crenomytilus grayanus, 1 spec., coll. A. Golikov, 20 March 1966; ZISP 3/46600, Sea of Japan, Peter the Great Bay, Vostok Bay, in estuary, $1 \mathrm{~m}$, from shells of oyster Crassostrea gigas, 30 spec., 16 October 1985, coll. V. Radashevsky; ZISP 4/46781, Sea of Japan, Vostok Bay, in estuary, 0.5 $\mathrm{m}$, from shells of oyster C. gigas, 20 spec., 3 September 1986, coll. V. Radashevsky; USNM 126513, Sea of Japan, Vostok Bay, in estuary, $1 \mathrm{~m}$, from shells of oyster C. gigas, 26 spec., 4 March 1989, coll. V. Radashevsky; NSMT-Pol. 97575-97579, Sea of Japan, Vostok Bay, in estuary, $3 \mathrm{~m}$, from shell of oyster C. gigas, 5 anterior ends and 5 posterior ends, 29 May 1991, coll. V. Radashevsky.

Description. Specimens up to $43 \mathrm{~mm}$ long and $1.6 \mathrm{~mm}$ wide for 160 segments. Oc- 


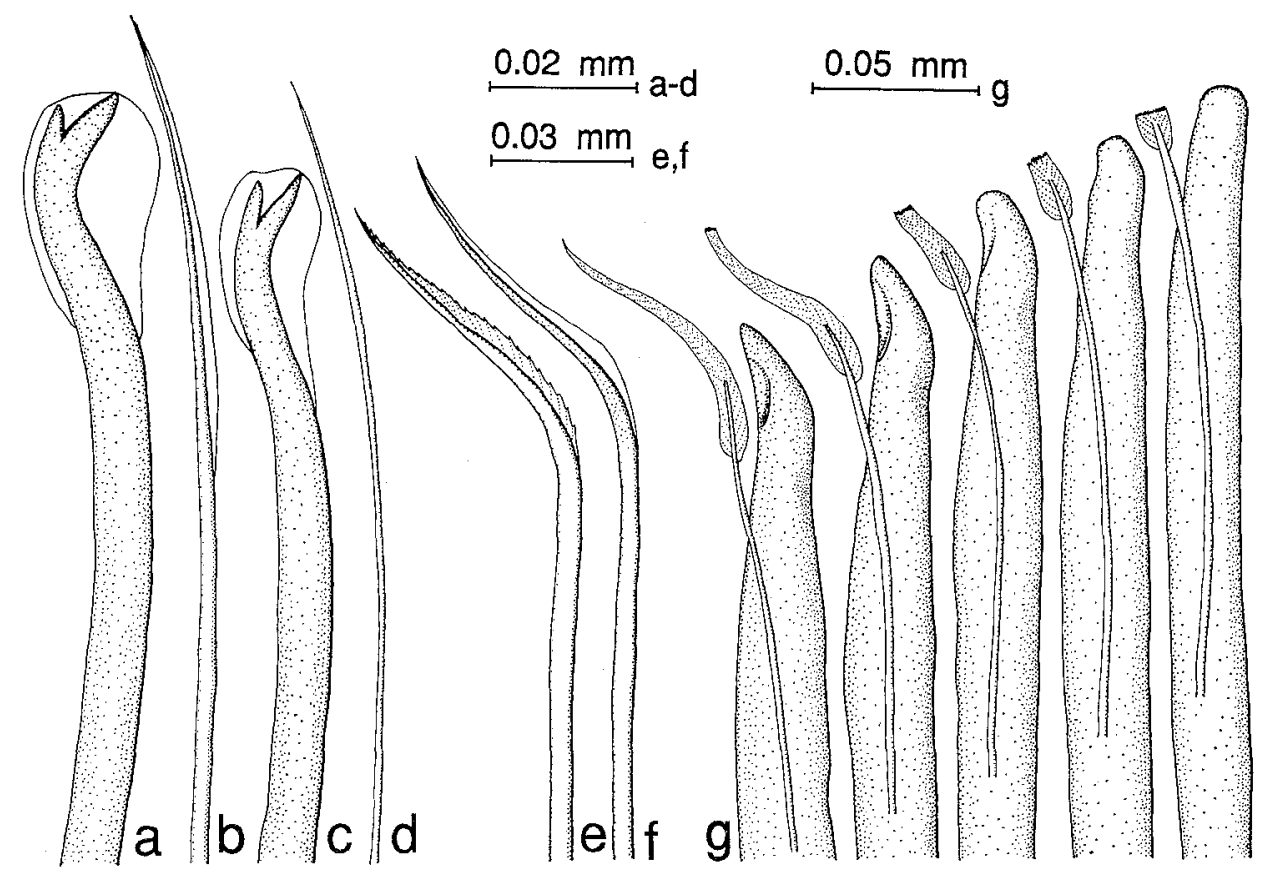

Fig. 3. Boccardiella hamata (Webster). a,b, bidentate hooded hook and winged capillary neuroseta of setiger 7 ; c,d, posterior hooded hook and unwinged capillary neuroseta; e, ventral capillary seta of setiger $5 ; \mathrm{f}$, dorsal capillary seta of setiger $5 ; \mathrm{g}$, heavy spines and pennoned companion setae of setiger 5 .

casionally, 60-80-segmented worms with larval black pigment on dorsal and ventral sides of anterior setigers. Body pigmentation in large specimens absent. Prostomium "T"-shaped anteriorly with shallow notch. Four eyes present. Caruncle continuing posteriorly to middle of setiger 3 or to middle of setiger 4 , most often to anterior margin of setiger 4. Nuchal tentacle absent (Fig. 2, a). Palps long, rusty coloured, extending posteriorly for 15-25 segments.

Setiger 1 with only neurosetae, although well developed notopodial lobe present. Notopodial winged capillary setae of setigers 2-4, 6, and succeeding segments arranged in three successive rows. Caudally, number of setae per notopodial fascicles gradually diminishing, setae becoming longer, capillaries of anterior row becoming thicker and losing wings (Fig. 2, c). Each posterior notopodium with single thick, recurved hook, besides capillaries (Fig. 2, e). These hooks appearing on setiger 19 in juveniles immediately after settlement and gradually lost with age beginning in adult specimens on setigers $100-150$.

Neuropodial bidentate hooded hooks from setiger 7, without constriction on shaft (Fig. 3, a,c), up to 11 in series, accompanied by capillary setae nearly in all setigers. In anterior setigers, accompanying capillaries winged (Fig. 3, b), up to 6 in tuft located below vertical row of hooks. In posterior segments, accompanying capillaries diminishing in number and becoming narrow and unwinged (Fig. 3, d).

Setiger 5 twice as large as neighbouring segments with row of heavy modified 
spines alternating with pennoned companion setae. Ventral fascicle of up to 15 winged setae (Fig. 3, e) and superior dorsal fascicle of up to 6 capillaries (Fig. 3, f) present. Modified spines falcate, without terminal supplementary structures (Fig. 3, g), up to 15 in number.

Branchiae present on setigers 2,3,6, and succeeding segments, except posterior third of body, ending in 10-15 segments before the appearance of notopodial hooks.

Pygidium with two broad ventral lappets, each having short terminal process (Fig. 2, b).

Glandular pouches from setiger 7, attaining full size in setiger 8 and diminishing in size after setigers 10-16.

Gizzard-like structure in digestive tract absent.

Remarks. The morphology of the present specimens agrees well with the description given by Blake (1966).

Ecology. In Peter the Great Bay Boccardiella hamata has been bound in estuaries at a depth of 1-5 $\mathrm{m}$ usually boring into shells of an oyster Crassostrea gigas (Thunberg) and occasionally of a scallop Mizuhopecten yessoensis (Jay). It can also inhabit mud tubes on the surface of oyster shells. Up to 10 worms occur in one shell. The species has been never found in tubes in sediment.

On the Pacific coast of North America $B$. hamata has been reported from oyster beds, estuarine mud, algal holdfasts, hermit crab shells, and other littoral habitats (Blake, 1966). On the East and Gulf coasts of North America the species is known to penetrate oyster shells or gastropod shells (Webster, 1879; Hartman, 1951). In Japan it inhabits muddy flats between crevices of rock (Okuda, 1937).

New record. First record for the Sea of Japan.

Distribution. Eastern coast of North America: from New Jersey south to Florida; Lousiana, Gulf of Mexico; Lagoon of Mandina, eastern Mexico; western coast of North America: from Vancouver Is., British Columbia south to Baja California; Pacific coast of Hokkaido, Japan; Peter the Great Bay of the Sea of Japan.

\section{Genus Neoboccardia Buzhinskaja, 1985}

Type species: Neoboccardia perata (Chlebovitsch, 1959), by monotypy.

Diagnosis: Prostomium anteriorly truncate, flattened and broadened. Unusual pocket or pouch present on ventral side of anterior segments. Setiger 1 with notosetae. Setiger 5 strongly modified with two types of major spines in double row. Bidentate hooded hooks from setiger 7, curved or quite straight, without constriction on shaft. Branchiae from setiger 2.

Remarks. Buzhinskaja (1985) noted that Neoboccardia differs from other spionids in the presence of a ventral pocket or pouch and in an unusual structure of the head. The genus is closely related to Boccardia in the presence of two types of spines on setiger 5 and in branchial arrangement. 


\section{Neoboccardia perata (Chlebovitsch, 1959)}

(Figures 4 \& 5)

Polydora (Boccardia) perata Chlebovitsch, 1959, pp. 176-178, fig. 7; 1961, p. 199.

Boccardia perata: Kussakin, 1975, p. 61.

Neoboccardia perata: Buzhinskaja, 1985, pp. 129-131, fig. 11.

Material examined. Polydora perata Chlebovitsch: ZISP 1/5241, Small Kurile Archipelago, Shikotan Is., Krabovaya Bay, intertidal, 31 spec., 1949, coll. E. Gurjanova; ZISP 2/5242-14/5254, Shikotan Is., Krabovaya Bay, intertidal, 258 spec., 1954-1955, coll. O. Kussakin; ZISP 15/5255, Shikotan Is., Krabovaya Bay, intertidal, 37 paratypes, 27 March 1955, coll. O. Kussakin; ZISP 16/41898, Shikotan Is., Krabovaya Bay, intertidal, holotype, 27 March 1955, coll. O. Kussakin. Neoboccardia perata (Chlebovitsch): ZISP 17/46783, Sea of Japan, Peter the Great Bay, Srednyaya Bight, $10 \mathrm{~m}$, sand, I spec., 1985, coll. A. Ozolinsh; ZISP 18/46784, Sea of Japan, Peter the Great Bay, Furugelm Is., 35 m, sand, 2 spec., 1985, coll. A. Ozolinsh; IMBV 2/12177, Sea of Japan, Peter the Great Bay, Stark Strait, $5-6 \mathrm{~m}$, in sand tubes on the surface of scallop $M$.yessoensis, 2 spec., 3 July 1987, coll. V. Radashevsky; USMN 126514, Small Kurile Archipelago, Shikotan Is., Otradnaya Inlet, intertidal, mud, 30 spec., 24 August 1987, coll. V. Radashevsky; NSMT-Pol. 97580 97589, Small Kurile Archipelago, Habomai, Yuri Is., intertidal, muddy sand, 10 spec., 19 June 1989, coll. V. Radashevsky.

Author's collections from off Small Kurile Archipelago: Yuri Is., intertidal, subtidal, 6-7 m; Shikotan Is., intertidal, subtidal, 5-6 m; many specimens.

Description. Specimens from off the Small Kurile Archipelago up to $70 \mathrm{~mm}$ long and $3 \mathrm{~mm}$ wide for 225 segments. Colour in life dark tan with greenish cast. Body with characteristic reticulate, black pigment pattern of varying intensity on peristomium around mouth, on lateral sides of prostomium and on first three segments. Diffuse transversal bands of black pigment present on palps. Numerous large mucous cells present on dorsal side of anterior 2/3 part of body, first appearing on setigers 13-20, giving body whitish appearance.

Prostomium truncate, flattended and broadened anteriorly, narrowed medially and broadened again posteriorly. Small specimens with distinct medial incision on anterior margin of prostomium. In large polychaetes that incision slightly developed. Posterior pair of eyes well distinguished, while anterior ones, one or two, covered by black reticulate pigment. Caruncle continuing posteriorly to setiger 4 or to middle of setiger 5 (Fig. 4, a). Palps long, extending posteriorly for 30-40 segments.

Characteristic body folds present on ventral side of anterior segments: small longitudinal folds on setigers 1-3 and large cross fold on setiger 4 (Fig. 4, b). These folds forming unusual pocket or pouch, from which the name of species is derived.

Setiger 1 with tuft of short capillary setae in notopodia. Succeeding anterior setigers (except setiger 5) with three types of notosetae, two cross rows of short, thick capillaries and medial tuft of longer, thinner capillaries. All three types of capillaries strongly pronounced in anterior setigers of large specimens. From more posterior setigers tufts feebly marked and capillaries more thinner. Specialized spines in posterior notopodia absent.

Anterior neuropodia (except setiger 5), as notopodia, with three types of capillary setae: two vertical rows of thick capillaries, and tuft of 5-10 thinner capillaries, 

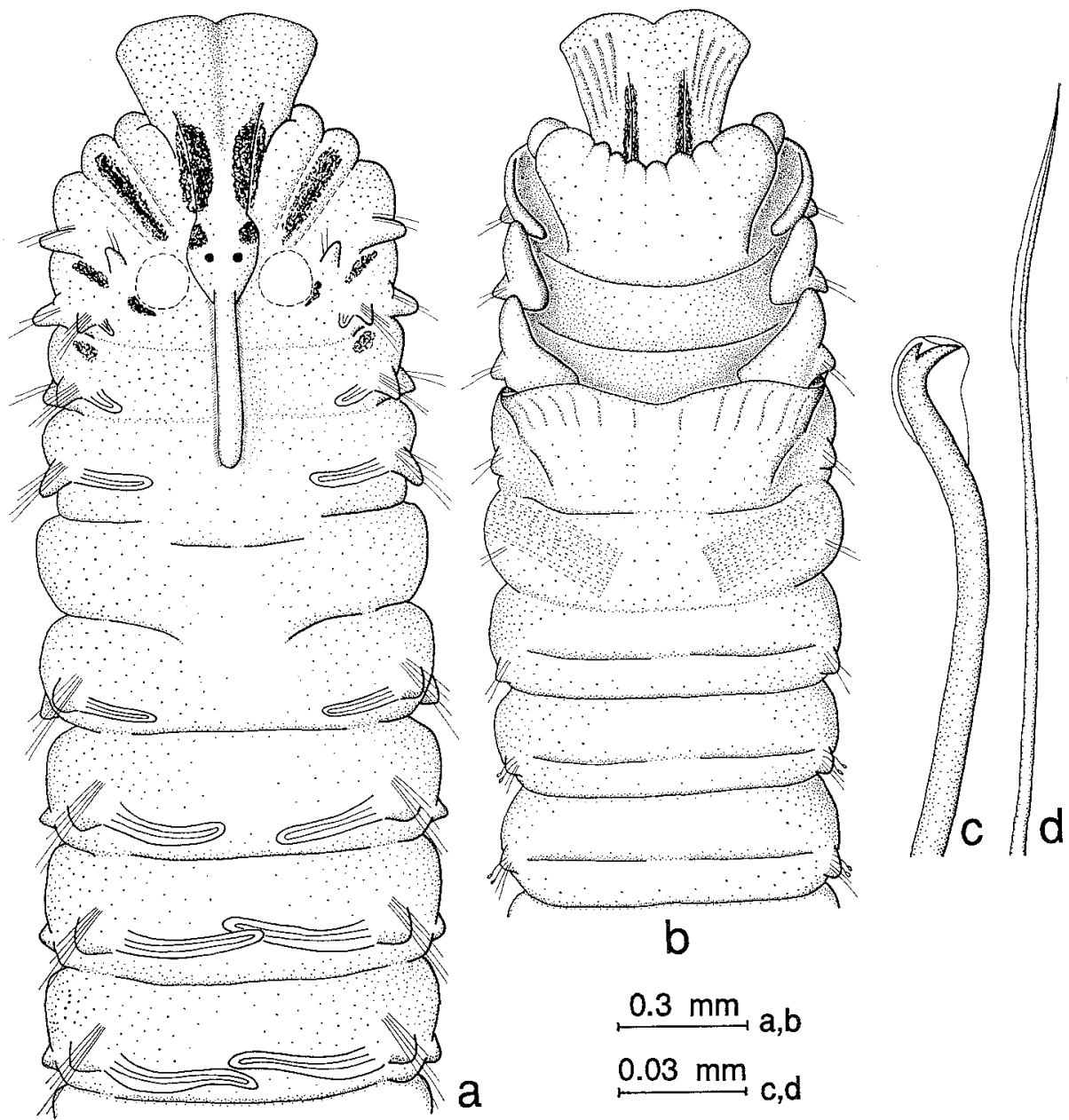

Fig. 4. Neoboccardia perata (Chlebovitsch). a, anterior end of 56-segmented specimen, dorsal view; $b$, the same, ventral view; c,d, bidentate hooded hook and winged capillary neuroseta of setiger 7 .

located below them. From setiger 7 both vertical rows of capillaries replaced by row of bidentate hooded hooks, setae of lower tuft becoming thinner (Fig. 4, d), their number gradually diminishing. After setigers $15-25$ neuropodia with one or two slender unwinged capillaries below hooks. In middle neuropodia capillaries not always observed. In small specimens, the capillaries occasionally absent, while in large worms capillaries absent from groups of segments. Far posterior neuropodia only with hooded hooks. Neuropodial bidentate hooded hooks without constriction on shaft (Fig. 4, c), numbering up to 13 in series.

Setiger 5 slightly modified, with ventral fascicle of up to 15 unilimbate capillaries, dorsal capillary setae absent. Modified spines of two types arranged in double row along segment, up to 13 in each row. Spines of upper row simple, falcate, with small spoon-like hollow on concave side (Fig. 5, a). Lower spines with 

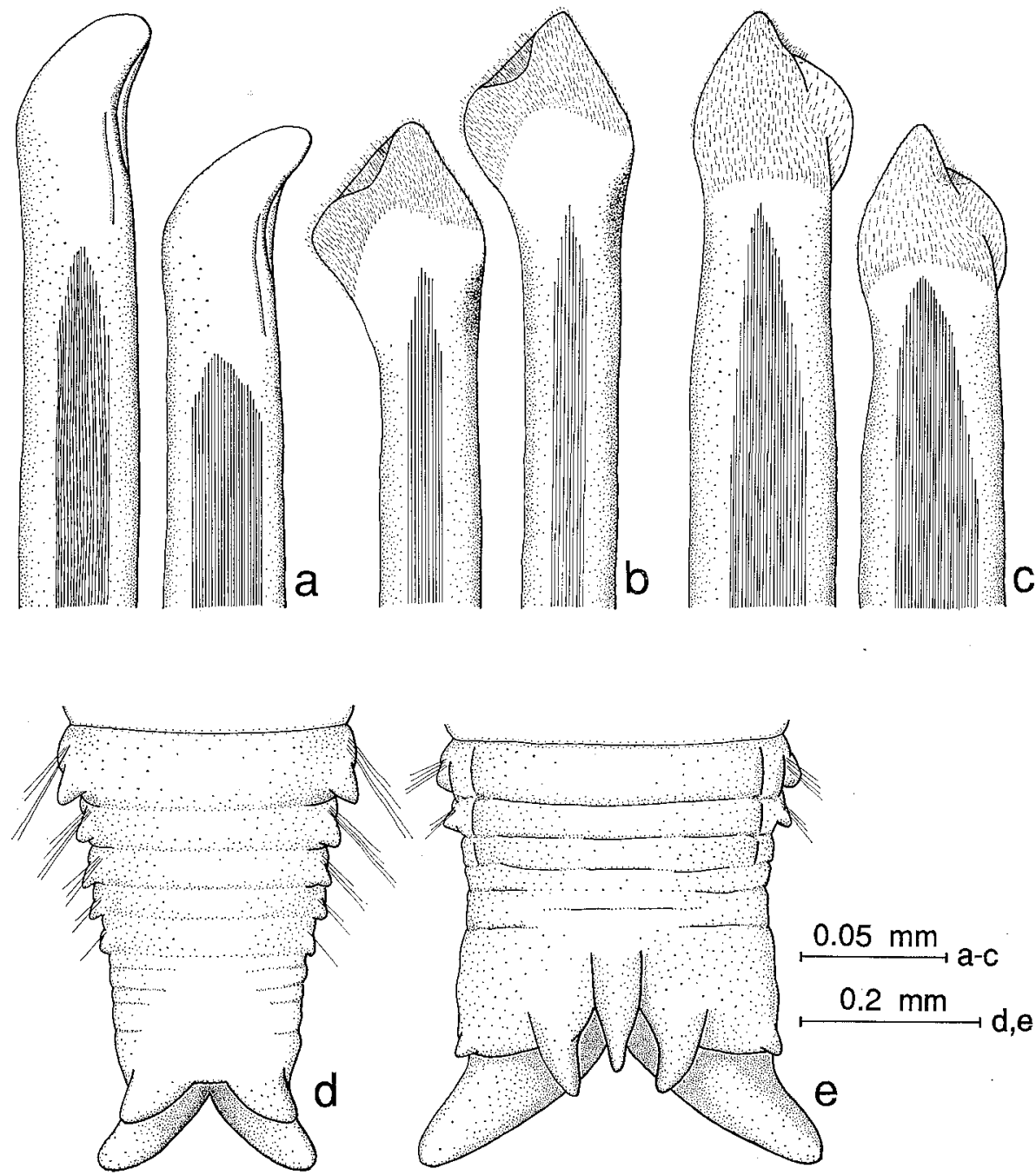

Fig. 5. Neoboccardia perata (Chlebovitsch). a, upper heavy spines of setiger 5 ; b, lower heavy spines of setiger 5, lateral view; c, the same, lateral-posterior view; $d$, posterior end of 56-segmented specimen, dorsal view; e, posterior end of 100segmented specimen, dorsal view.

enlarged tip having cavity covered by bristles (Fig. 5, b, c).

Branchiae present on setigers $2-4,6$, and succeeding segments, except posterior $1 / 3-1 / 4$ part of body. The branchia fused basally to dorsal lamellae, small at first, then increasing in size, but in posterior segments decreasing again.

Pygidium variable, depending upon animal age. Up to 60-80-segment stage worms with four pygidial lobes, dorsal pair being smaller than ventral one (Fig. 5, d). New lobes, three or more, appearing with age on dorsal side of pygidium (Fig. $5, \mathrm{e})$.

Glandular pouches from setiger 6 , small at first, increasing in size posteriorly to 
setiger 9. Pouches of setiger 9 so large that occupying setiger 10 . Pouches of succeeding setigers tiny.

Intestine, beginning from setigers 20-30, through ten to twenty segments with more developed wall musculature than that in preceding and succeeding segments. Ecology. Neoboccardia perata constructs tubes in muddy substrata. In Peter the Great Bay it has been found subtidally at a depth of 4-35 m, off south-eastern coast of Sakhalin (Vzmorye) at a depth of $23 \mathrm{~m}$ (Buzhinskaja, 1985), and off Small Kurile Archipelago (Shikotan Is., Yuri Is.) in lower intertidal area and subtidally at a depth of 5-7 m. The population density of this species was up to several thousand individuals per 1 square metre in intertidal areas and to several ten or hundred individuals per 1 square metre in subtidal areas.

The tubes of $N$. perata are formed of silt, and grey coloured. They have thick walls with rust-coloured parchment inside. The lower part of the tubes is wider than the upper, with a diameter of up to $8.5 \mathrm{~mm}$. The tubes are up to $15 \mathrm{~cm}$ in length, and project $0.5-1 \mathrm{~cm}$ above the surface of the bottom.

Remarks. The polychaetes of this kind were for the first time found and described by I. Zachs from the subtidal zone of the Okhotsk Sea coast of Kamchatka. Unfortunately, the description of a new species was not published and the type material was lost. Nevertheless, the manuscript and drawings were deposited in ZISP, and some drawings have been published by Buzhinskaja (1985).

New record. First record for the Sea of Japan.

Distribution. Small Kurile Archipelago; Okhotsk Sea coast of southern Sakhalin; Peter the Great Bay of the Sea of Japan; ? Okhotsk Sea coast of southern Kamchat$\mathrm{ka}$.

\section{Genus Polydora Bosc, 1802}

Type species: Polydora cornuta Bosc, 1802.

Diagnosis: Prostomium narrow, anteriorly rounded to bifid. Setiger 1 with or without notosetae. Setiger 5 greatly modified with one type of major spine in single curved row, usually accompanied by slender companion setae. Bidentate hooded hooks from setigers 7-17, curved or quite straight, with or without constriction on shaft. Brachiae posterior to setiger 5 .

Key to the species of Polydora from the North West Pacific ("denotes species found by the author in the North West Pacific but not included in the present paper)

1. Branchiae from setiger 6. Neuropodial hooded hooks from setigers 12-17. Bores into gastropod shells occupied by hermit crabs............. commensalis

- Branchiae from setigers 7-10. Neuropodial hooded hooks from setiger 7. Bores into various substrata or inhabits mud tubes..............................

2(1). Setiger 1 without notosetae. Neuropodial hooded hooks with constriction

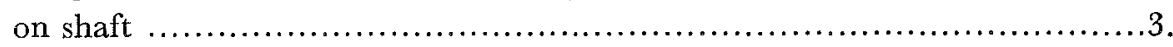

- Setiger 1 with notosetae. Neuropodial hooded hooks without constriction

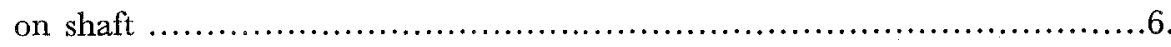


3(2). Inhabits mud tubes on shore or in fouling $\ldots \ldots \ldots \ldots \ldots \ldots \ldots \ldots$. limicola

- Bores into sponges............................................ spongicola

- Bores into calcareous substrata.........................................4.

4(3). Nuchal tentacle present. Bores into shells of bivalve Glycymeris yessoensis

- Nuchal tentacle absent. Bores into other calcareous substrata ..............5.

5(4). Prostomium rounded. Palps with cross black bands. Bores into shells of scallop Mizuhopecten yessoensis ................................ brevipalpa

- Prostomium incised. Palps without cross black bands. Bores into various calcareous substrata .......................................... $* P$. cf. ciliata

6(2). Posterior notopodial spines awl-shaped. Branchiae from setiger 7. Inha-

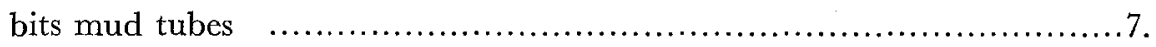

- Posterior notopodial spines needle-like or absent. Branchiae usually from setigers 8-10. Inhabits mud tubes or bores into various substrata ........8.

7(6). Modified spines of setiger 5 bifid, with bushy tufts between teeth..............

P. quadrilobata

- Modified spines of setiger 5 falcate, with pectinate or bushy tops.

$* P$. cf. caulleryi

8(6). Pygidium cup-shaped with single dorsal incision. Bores into calcareous substrata, occasionally into sponges $P$. carunculata

- Pygidium with three or four lobes. Inhabits mud tubes or bores into various calcareous substrata ...............................................9.

9(8). Modified spines of setiger 5 straight, with small subterminal enlargment.

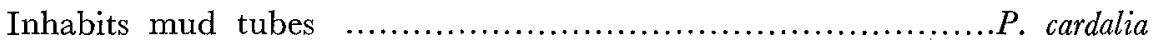

- Modified spines of setiger 5 falcate, with lateral tooth or flange. Bores into

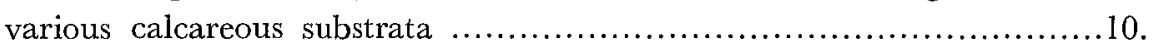

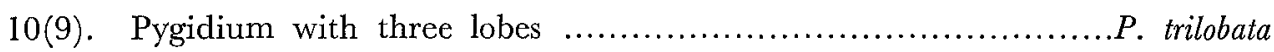

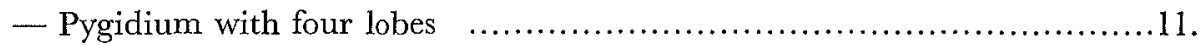

11(10). Posterior notopodia with needle-like spines .................... bidentata

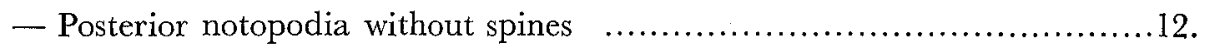

12(11). Caruncle to setiger 3. Branchiae from setigers 9-10......... alborectalis

- Caruncle to middle or to end of setiger 4. Branchiae usually begin on setiger 8 P. concharum

\section{Polydora commensalis Andrews, 1891}

(Figure 6)

Polydora commensalis Andrews, I89la, pp. 25-35, 2 pls; 1891b, pp. 291-292, pl. 14, fig. 27. --Annenkova, 1938, p. 178, fig. 14. --Hartman, 1941, p. 308; 1945, p. 32; 1961, p. 29; 1969, pp. 133-134, 4 figs. --Rioja, 1943, p. 229. --Berkeley \& Berkeley, 1936, pp. 469-471; 1952, pp. 18-19, figs 29-30; 1956, p. 237. --Uschakov, 1955 (Part.), p. 271, fig. 93, syn., excl. P. ciliata brevipalpa. --Hatfield, 1965, pp. 356-368, figs 1-5. --Blake, 1969a, pp. 815-816, fig. 3; 1969b, pp. 21-24, figs 16-18; 1971 (Part.), pp. 17-20, fig. 11, syn., excl. P. ciliata brevipalpa. --Foster, 1971 (Part.), pp. 20-22, figs 1-12, syn., excl. P. ciliata brevipalpa. --Blake \& Evans, 1973, pp. 
241-247, fig. 3 a-b. --Hoberg, McGee \& Feder, 1982, pp. 168-174. --Dauer, 1991, pp. 607-614. Not Polydora ciliata brevipalpa Zachs, 1933, p. 129.

Material examined. Polydora commensalis: ZISP 1/25691, Sea of Japan, Siaukhu Bay, 1.5-2 m, from shell of gastropod Natica clausa occupied by hermit crab Eupagurus ochotensis, 4 spec., 8 October 1934, det. N. Annenkova; ZISP 2/46575, Sea of Japan, Vostok Bay, $3 \mathrm{~m}$, from shells of gastropod Cryptonatica janthostoma occupied by hermit crab Pagurus capillatus, 14 spec., 17 June 1984, coll. V. Radashevsky; ZISP 3/46602, Sea of Japan, Vostok Bay, 2 m, from shell of gastropod Littorina squalida occupied by hermit crab Pagurus middendorffi, 1 spec., 22 September 1985, coll. V. Radashevsky; ZISP 4/46775, Sea of Japan, Uspeniya Bay, 8-10 m, from shells of gastropod C. janthostoma occupied by hermit crab Pagurus sp., 8 spec., 27 July 1986, coll. V. Radashevsky; NSMT-Pol. 97610-97619, Sea of Japan, Vostok Bay, $3 \mathrm{~m}$, from shells of gastropod C. janthostoma occupied by hermit crab P. capillatus, $10 \mathrm{spec}, 15$ March 1990, coll. V. Radashevsky.

Author's collections from off mainland coast of the Sea of Japan from Chikhachev Bay south to East Korean Bay; Sakhalin Is.: Pyata Point of Terpeniya Bay, Velikan Point of Tonino-Anivsky Peninsula, and Aniva Bay; Moneron Is.; Prostor Bay and Dobroye Nachalo Bay both of Iturup Is.; Izmeny Bay of Kunashir Is.; Shikotan Is.; Yuri Is.; Tanfiliyev Is.; many specimens.

Description. Specimens dorsoventrally flattened, up to $75 \mathrm{~mm}$ long and $2.5 \mathrm{~mm}$ wide for 300 segments. Colour in life dark tan. Red blood vessels prominent. Prostomium usually bifurcated or bifid and curved downward anteriorly, but occasionally rounded. Entire head usually contracted into first setiger. Caruncle absent (Fig. 6, a). Two eyes present or eyes absent. Palps short, reaching posteriorly to setigers 5-7. Nototrochs present from segment 1.

Setigers 1-4 with well developed noto- and neuropodial lobes having fascicles of long capillary setae. Notosetae of setigers 1-2 directed anteriorly and longer than those of succeeding setigers. Specialized setae in posterior notopodia absent. Capillary neurosetae of anterior setigers arranged in two bundles: upper group of $10-$ 15 long and thick setae (Fig. 6, c), and lower group of 3-5 shorter and thinner setae (Fig. 6, d). Beginning on setiger 12, number of setae per groups diminishing, setae of upper group arranged in vertical row with hooded hooks among them (Fig. 6, e, f). After setigers 20-25 lower neurosetae disappearing, while upper fascicles containing hooded hooks and 1-3 capillaries. Caudally, these capillaries becoming thinner and losing wings (Fig. 6, h). Remarkably, hooded hooks beginning on setiger 12 only in small specimens, gradually lost with age, beginning on setigers $15-17$ in large specimens. Number of hooks increasing in middle region and reducing posteriorly, also depending on worm size; large specimens with up to 18 hooks in middle setigers. Hooks bidentate, without constriction on shaft (Fig. 6, e, g).

Setiger 5 modified, with row of heavy spines alternating with very small companion setae (Fig. 6, i). Ventral tuft of capillary setae present but dorsal one absent. Spines falcate, curved, with characteristic long lateral flange or sheath, up to 10 in series.

Branchiae long and strap-like, with membranous margins, beginning on setiger 6 and continuing to end of body, decreasing in size.

Anus surrounded by ring of small papillae, number of which depending upon worm age. Juveniles with 4 papillae (Fig. 6, b), while large worms with up to 14 .

Glandular pouches from setiger 6, well developed at first and reduced after seti- 

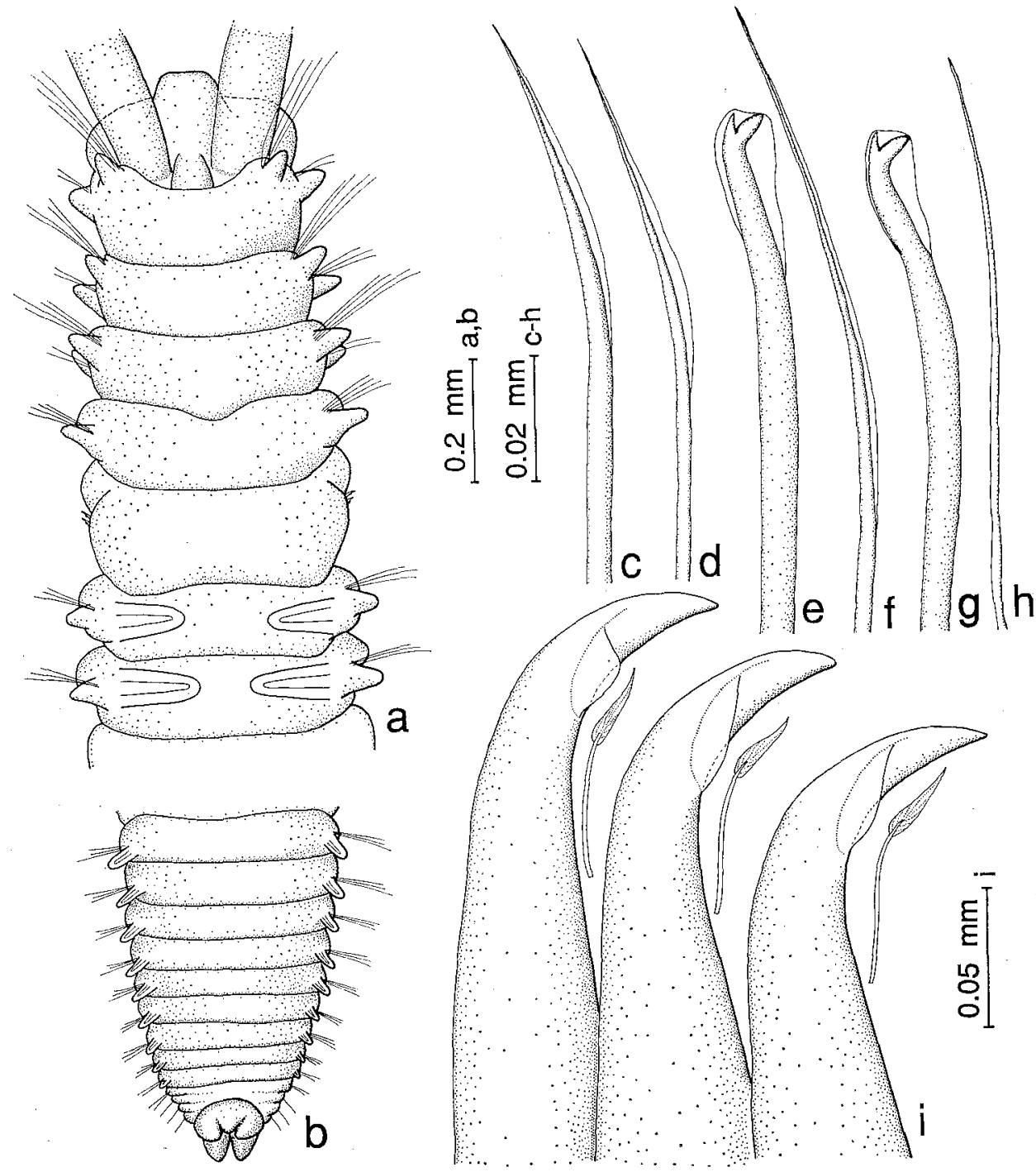

Fig. 6. Polydora commensalis Andrews. a, anterior end, dorsal view; b, posterior end, dorsal view; c, upper group capillary neuroseta of setiger 11 ; d, Iower group capillary neuroseta of setiger 11 ; e, $\mathrm{f}$, bidentate hooded hook and winged capillary neuroseta of setiger $14 ; \mathrm{g}, \mathrm{h}$, hooded hook and unwinged capillary neuroseta of setiger $50 ; i$, heavy spines and small companion setae of setiger 5.

gers $20-25$.

Gizzard-like structure in digestive tract absent. Stomach wall of large worms with numerous nutrient granules.

Remarks. The morphology of author's specimens agrees well with the descriptions of $P$. commensalis given by Andrews (1891a, b) and Blake (1971). However, they did not report very small companion setae of setiger 5 . 
Uschakov (1955), Foster (1971), and Blake (1971) included Polydora ciliata brevipalpa Zachs, 1933 in the synonymy of $P$. commensalis, since Zachs (1933) included $P$. commensalis Andrews, 1891 in the synonymy of $P$. ciliata Johnston subsp. n. brevipalpa. However, as shown below (see P. brevipalpa) Zachs' subspecies is a distinct species.

Ecology. Polydora commensalis is a commensal of hermit crabs. It has been found intertidally and subtidally to a depth of $30 \mathrm{~m}$ in shells of gastropods Cryptonatica janthostoma (Deshayes), C. hirasei (Pilsbry), C. wakkanaiensis Habe et Ito, Lunatia pila (Pilsbry), L. pallida (Broderip et Sowerby), Buccinum middendorffi Verkrüzen, Nucella heyseana (Dunker), Boreotrophon candelabrum (A. Adams et Reeve) and Littorina squalida Broderip et Sowerby, occupied by Pagurus middendorffi Brandt, P. capillatus (Benedict) and $P$. brachiomastus (Thallwitz). Up to 70 worms can occur in one shell, but usually there are about 10. Shells covered by a hyroid Hydractinia sp. are more heavily infested by $P$. commensalis. Most of the population of $P$. commensalis are small juveniles and males. No more than one female occurs in one shell.

Unlike other polydorid-borers, which make a burrow opening on the outside surface of the shell, in $P$. commensalis the burrow is located in the column and opens on the inside of the shell. Such a position of the burrow may be primarily due to the mode of feeding in this species. The worms catch suspended particles from the water current produced by the host hermit crab during respiration. These particles can either be carried by the water current from outside or are the remains of the crab's meal. Owing to such a mode of feeding, $P$. commensalis has short palps and lives only in gastropod shells occupied by hermit crabs. Nutrient granules in the polychaete stomach wall ensure the survival of the worms during the temporary absence of their host.

New record. First record for Sakhalin and for the Kurile Islands.

Distribution. Eastern coast of North America: from Wedgeport, N.S., Canada south to Beaufort, North Carolina; western coast of North America: from Norton Sound, Alaska south to Mazatlan, Mexico; mainland coast of the Sea of Japan: from Chikhachev Bay south to East Korean Bay; Moneron Is.; Sakhalin Is.; Kurile Islands: Iturup Is., Kunashir Is., and Small Kurile Archipelago.

\section{Polydora concharum Verrill, 1880}

(Figures $7 \& 8$ )

Polydora concharum Verrill, 1880, pp. 174-176. --Blake, 1969a, p. 816, fig. 4; 1969b, pp. 32-36, figs 23-26; 1971, p. 20, fig. 12, syn. --Blake \& Dean, 1973, p. 34. --Blake \& Evans, 1973, pp. 239247, figs 3 h, 4. --Evans, 1969, pp. 775-782, figs 3-4. --Mori et al., 1985, pp. 371-379.

Material examined. Polydora concharum: ZISP 1/46590, Sea of Japan, Vostok Bay, $70 \mathrm{~m}$, from shells of gastropod Neptunea constricta, 35 spec., 23 March 1984, coll. V. Radashevsky; ZISP 2/46601, Sea of Japan, Vostok Bay, $50 \mathrm{~m}$, from shell of gastropod $N$. constricta, 1 spec., 19 February 1985, coll. V. Radashevsky; ZISP 3/46776, Sea of Japan, Vostok Bay, 50-70 m, from shells of gastropod $N$. constricta, many spec., 3 April 1985, coll. V. Radashevsky; ZISP 4/46777, Sea of Japan, Vostok Bay, 6 m, from shell of bivalve Mercenaria stimpsoni, 2 spec., 29 August 1983, coll. V. Radashevsky; 
USNM 126518, Sea of Japan, Vostok Bay, $50-60 \mathrm{~m}$, from shells of gastropod $N$. constricta, 30 spec., 13 March 1989, coll. V. Radashevsky; NSMT-Pol. 97620-97631, Sea of Japan, Vostok Bay, $60 \mathrm{~m}$, from shell of gastropod $N$, constricta, 2 whole spec., 10 anterior ends, 3 posterior ends, $26 \mathrm{Ja}-$ nuary 1986, coll. V. Radashevsky.

Author's collections from off mainland coast of the Sea of Japan from Toki Is, south to East Korean Bay; many specimens.

Description. Specimens up to $145 \mathrm{~mm}$ long and $1.4 \mathrm{~mm}$ wide for 320 segments. Colour in life light tan. Some specimens with thin, dark band along ciliated groove on palps. Prostomium distinctly bifid on anterior margin. Eyes absent, or either two or four eyes present. Caruncle continuing posteriorly to middle or to posterior border of setiger 4. Nuchal tentacle absent (Fig. 7, a). Palps extending posteriorly to setigers 14-28.

Setiger 1 with well developed noto- and neuropodial lobes having capillary setae. Notosetae of setigers 2-4, 6, and following setigers arranged in three successive rows, notosetae of each succeeding row being longer. Caudally, setae of anterior row becoming thicker and shorter, losing wings (Fig. 8, a), whereas those of posterior row thinner, longer and winged (Fig. 8, b). Winged neurosetae of setigers $2-4$ and 6 ar-

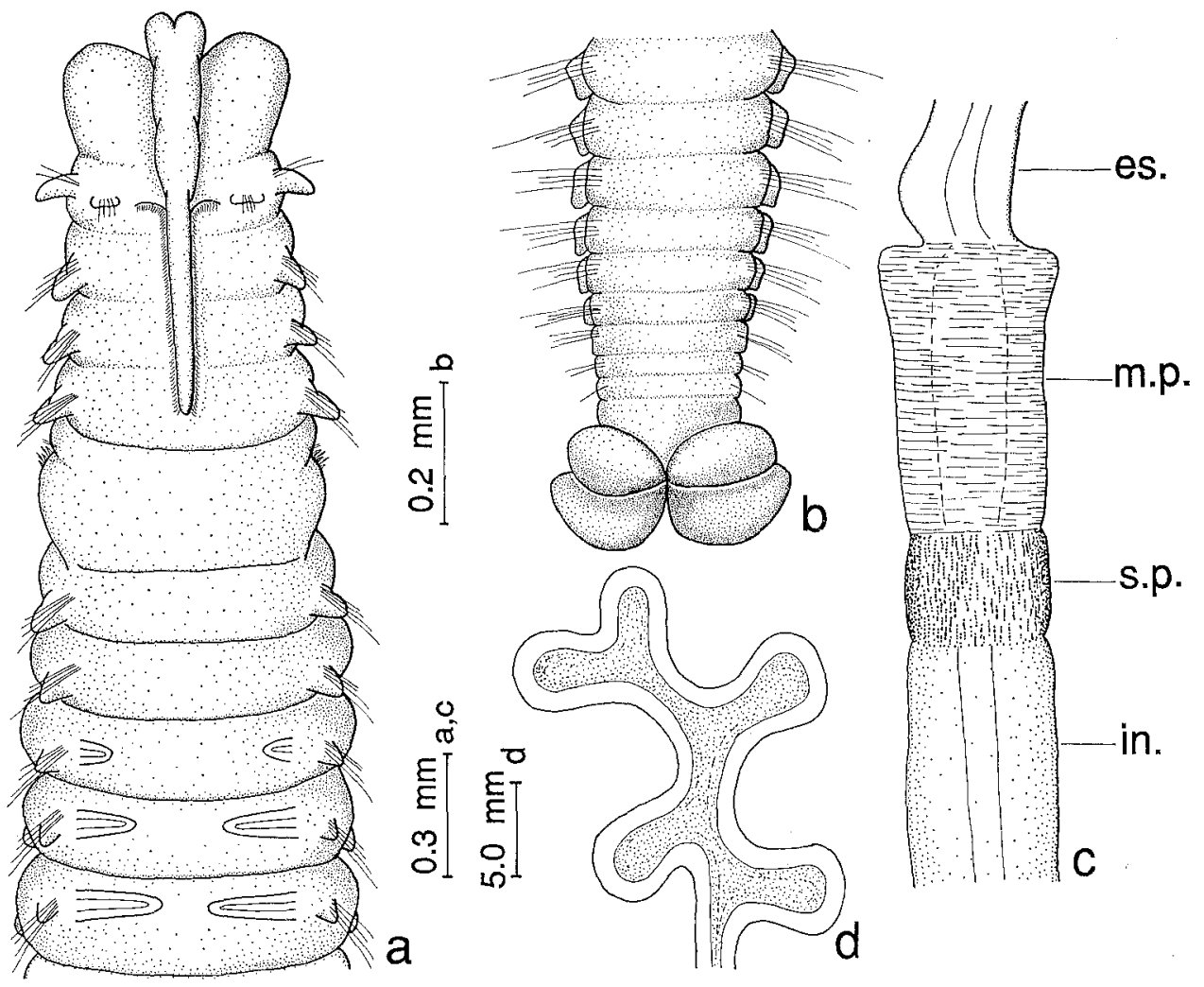

Fig. 7. Polydora concharum Verrill. a, anterior end, dorsal view; b, posterior end, dorsal view; c, gizzard-like structure in the digestive tract; $d$, branching burrow in a shell. es. -esophagus, m.p. -muscular part, s.p. -secretory part, in. -intestine. 


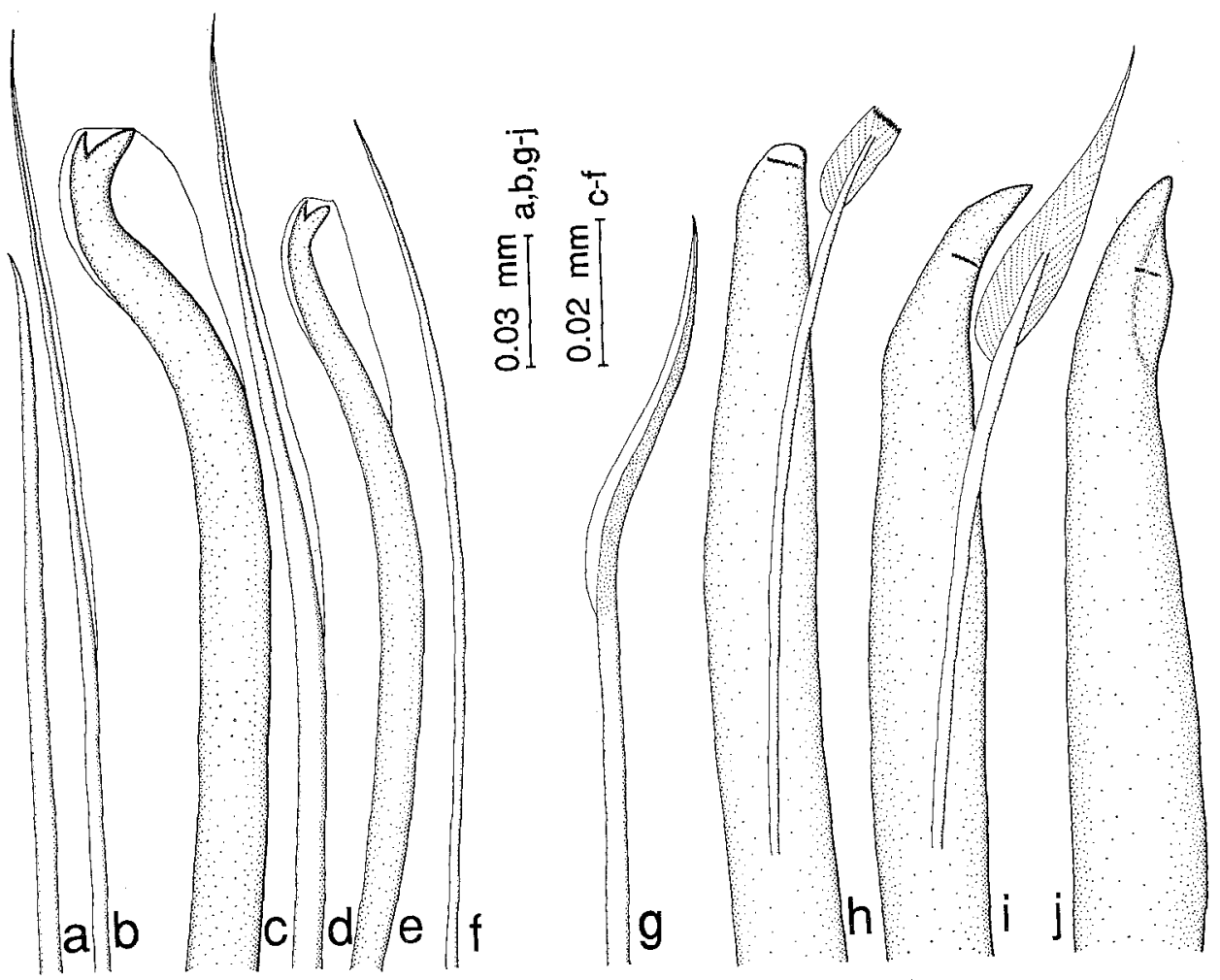

Fig. 8. Polydora concharum Verrill. a, b, posterior unwinged and winged capillary notosetae; c, d, bidentate hooded hook and winged capillary neuroseta of setiger 7; e, f, posterior hooded hook and unwinged capillary neuroseta; $g$, dorsal seta of setiger $5 ; \mathrm{h}$, worn heavy spine and pennoned companion seta of setiger $5 ; \mathrm{i}$, unworn heavy spine and pennoned companion seta of setiger 5 ; $\mathrm{j}$, heavy spine of setiger 5 .

ranged in two rows. Neuropodial bidentate hooded hooks from setiger 7, without constriction on shaft (Fig. 8, c, e), up to 7 in series. Up to four winged capillary setae accompanying hooks to setigers 15-20 (Fig. 8, d), then disappearing, and up to five slender capillaries appearing again in far posterior setigers (Fig. 8, f).

Setiger 5 larger than preceding and succeeding setigers, with bundle of up to 7 dorsal setae (Fig. 8, g), semicircular row of large heavy spines, alternating with pennoned companion setae, and ventral tuft of up to 11 winged neurosetae. Heavy spines falcate, up to 10 in series, with weakly-developed accessory shelf on convex side of tip (Fig. 8, h-j). Occasionally accessory shelf absent.

Branchiae usually from setiger 8 and occasionally from setiger 7 or 9 , small anteriorly, reaching full size on setigers $10-15$ and absent from posterior half or one third of body.

Pygidium white, with four lobes (Fig. 7, b).

Glandular pouches from setiger 6, small at first, attaining full size in setigers 89 and diminishing in size after setigers 15-20. 
Gizzard-like structure in digestive tract present, beginning in setigers 18-41 and continuing for two or four segments, consisting of anterior transparent, muscular part and posterior white, apparently secretory part (Fig. 7, c). Rectum usually white, continuing for 10-20 hinder segments.

Remarks. The specimens well agree with a detailed description of $P$. concharum given by Blake (1971). However, they have a gizzard-like structure and white-coloured rectum, which are not observed by Blake and other investigators.

Ecology. $P$. concharum is a borer of shells. In Peter the Great Bay the species commonly occurs at a depth of 50-100 m in shells of living gastropods Neptunea constricta (Dall), $N$. polycostata Scarlato, N. lyrata (Gmelin), N. bulbacea (Bernardi), Buccinum verkruzeni Kobelt, Crepidula derjugini Golikov et Kussakin, Turritella fortilirata Sowerby and in empty shells of Buccinum verkruzeni, Plicifusus plicatus (A. Adams) occupied by hermit crabs. P. concharum bores also into shells of a bivalve Pandora wardiana (A. Adams). Two specimens of this species have been found in shell of a bivalve Mercenaria stimpsoni (Gould) at a depth of $5 \mathrm{~m}$ in Vostok Bay and at a depth of 8-10 m in Uspeniya Bay. In Olga Bay and Vladimir Bay $P$. concharum has been found at $10-15 \mathrm{~m}$ in shells of a scallop Mizuhopecten yessoensis, while in East Korean Bay it has been found in shells of the same scallop at $27 \mathrm{~m}$.

The burrows of $P$. concharum are very branching (Fig. 7, d). The worms commonly form dense aggregations damaging the occupied shells.

New record. First record for the Sea of Japan.

Distribution. Eastern coast of North America: from Newfoundland south to Cape Cod, Massachusetts; Little Hellefiske Bank, West Greenland; mainland coast of the Sea of Japan: from Toki Is. south to East Korean Bay; Okhotsk Sea coast of Hokkaido, Japan.

\section{Polydora quadrilobata Jacobi, 1883}

(Figure 9)

Polydora quadrilobata Jacobi, 1883, p. 3, 2 pls. --Mesnil, 1897, pp. 87-88, pl. III: figs 9-11. --Fauvel, 1927, p. 54, fig. 18 1-r. --Annenkova, 1931, pp. 203-205; 1932a, p. 177; 1932b, pp. 134$136 ; 1937$, p. 170; 1938, p. 178; 1952, p. 126. --Berkeley \& Berkeley, 1943, p. 130; 1954, p. 464. --Uschakov, 1950, p. 201 ; 1953, p. 145; 1955, p. 272, fig. 94 A-G. --Rasmussen, 1973, pp. 111 112. --Hannerz, 1956, pp. 122-123. --Hempel, 1957, pp. 276-278. --Slastnikov, 1957, pp. 411427. --Chlebovitsch, 1961, p. 201. --Hartman, 1961, p. 100; 1969, pp. 145-146, 4 figs. --Blake, 1969b, pp. 37-51, figs 27-37; 1971, pp. 13-15, fig. 9. --Hartmann-Schröder, 1971, pp. 308310, fig. 104. --Kussakin, 1975, p. 61.--Light, 1977, p. 70. --Hobson \& Banse, 1981, p. 40, fig. 5 m.--Tzetlin et al., 1983, p. 170. --Bick \& Gosselck, 1985, pp. 237-239, figs 29/2, 30/6. --Sirenko et al., 1988, p. 46.

Material examined. Polydora quadrilobata Jacobi; ZISP 12/25719, Sea of Japan, Peter the Great Bay, 210-170 m, 6 October 1931, coll. K. Derjugin; ZISP 19/5311, Small Kurile Archipelago, Shikotan Is., Krabovaya Bay, intertidal, 1949, coll. E. Gurjanova; ZISP 40/47044, Tartar Strait, Chikhachev Bay, Ustrichny Is., 9-10 m, muddy sand, 2 spec., 22 August 1982, coll B. Sirenko; ZISP 41/47045, Tartar Strait, Chikhachev Bay, $1 \mathrm{~m}$, sand, 2 spec., 20 August 1982, coll. B. Sirenko; ZISP 42/48427, Middle Kurile Islands, Yankich Is., Kraternaya Bight, between two islets, 15 m, mud + shells, 3 spec., 2 July 1988, coll. V. Radashevsky; ZISP 43/48428, Yankich Is., Kraternaya Bight, south-western part of the bight, 5-7 m, muddy bottom, 30 spec., 19 July 1988, coll. 
V. Radashevsky; ZISP 44/48429, Yankich Is., Kraternaya Bight, south-western part of the bight, $10 \mathrm{~m}$, muddy bottom, 17 spec., 22 July 1988, coll. V. Radashevsky; IMBV 1/4688, Bering Sea, Anadyr Bay, Krest Bay, intertidal, 5 spec., 14 August 1968, coll. M. Ivanova; IMBV 2/12178, Okhotsk Sea, Sakhalin Is., Piltun Bay, 48 m, sand, 5 spec., 12 August 1990, coll. A. Smirnov; IMBV 3/12179, Okhotsk Sea, Sakhalin Is., Lunsky Bay, 19 m, sand, 1 spec., 17 August 1990, coll. A. Smirnov; IMBV 4/12180, Okhotsk Sea, Piltun Bay, $25 \mathrm{~m}$, sandy mud, many spec., 11 August 1990, coll. A. Smirnov; USNM 135423, North Japan Sea, mainland coast, Andrei Point, $7 \mathrm{~m}$, muddy sand, 10 spec., 26 July 1990, coll. V. Radashevsky; NSMT-Pol. 97632-97636, Sea of Japan, Tartar Strait, Andrei Point, $7 \mathrm{~m}$, muddy sand, 5 spec., 26 July 1990, coll. V. Radashevsky; UAMF 1987-7, Aleutian Islands, Shumagin Islands, Popov Is., Mud Bay, intertidal, muddy sand, 2 spec., 8 May 1985.

Author's collections from off the mainland coast of the Sea of Japan: Chikhachev Bay, Andrei Point; Pyata Point of Terpeniya Bay, Sakhalin Is.; Yuri Is. of Small Kurile Archipelago; Kraternaya Bight of Ushishir Islands; Zabiyaka Bay of North Okhotsk Sea; many specimens.

Description. Specimens up to $50 \mathrm{~mm}$ long and $1 \mathrm{~mm}$ wide for 140 segments. Colour in life light tan. Anterior end with black, reticulated pigmentation dispersed on sides of peristomium and on anterior setigers from 1 to 5-10. Intensity of pigmentation reducing caudally and varying between individuals. Prostomium distinctly bifid on anterior margin. Four eyes usually arranged in nearly straight transverse line. Two small black spots usually present behind lateral eyes. Indistinct caruncle continuing posteriorly to setiger 3 or 4 , or to middle of setiger 4 . Nuchal tentacle absent (Fig. 9, a). Palps extending posteriorly for 15-35 segments.

Setiger 1 with well developed noto- and neuropodial lobes having capillary setae. Capillary notosetae of setigers 2-4, 6, and following setigers arranged in three successive rows, notosetae of each succeeding row being longer than preceding ones. Caudally, number of setae per notopodium diminishing. Each posterior notopodium with heavy, awl-shaped spines besides capillaries (Fig. 9, i). These spines beginning in posterior branchial setigers and disposed in semicircular arrangement, at first 1-3 in tuft, and then up to 20. Neuropodial bidentate hooded hooks from setiger 7, without constriction on shaft (Fig. 9, e, g), up to 8 in series, accompanied by capillary setae in all setigers. In anterior setigers, accompanying capillaries winged (Fig. $9, \mathrm{f}$ ), up to 5 in tuft, located below vertical row of hooks. In posterior segments, capillaries diminishing in number, becoming narrow and unwinged (Fig. 9, h).

Setiger 5 larger than neighbouring segments, with horizontally curved row of up to 13 heavy, modified spines, having curved, bifurcated, bushy-topped distal end (Fig. 9, c, d). Companion setae between spines absent. Dorsal fascicle of up to 9 capillaries and ventral fascicle of up to 13 capillaries present.

Branchiae from setiger 7, small at first, attaining full size on setigers 10-12, absent from posterior half or one third of body.

Pygidium with four white, subequal lobes (Fig. 9, b).

Glandular pouches from setiger 6 , small at first, attaining full size in setigers 7-8 and then diminishing in size.

Gizzard-like structure in digestive tract absent.

Ecology. Polydora quadrilobata constructs mud tubes in sediment. The tubes are up to $8 \mathrm{~cm}$ in length. The upper part of tubes is greyish, smooth, $1-1.5 \mathrm{~mm}$ in dia- 

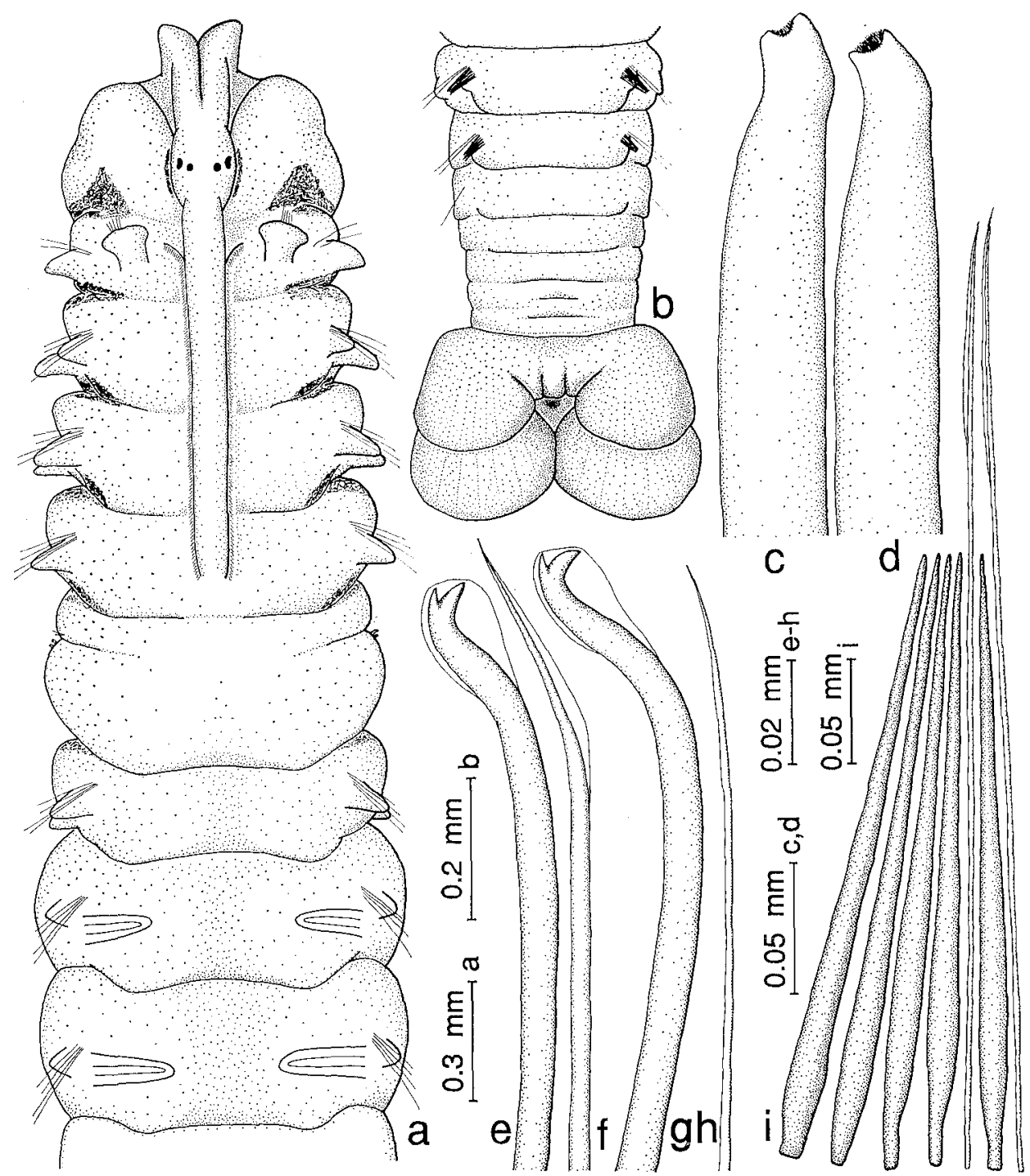

Fig. 9. Polydora quadrilobata Jacobi. a, anterior end, dorsal view; b, posterior end, dorsal view; c, worn heavy spine of setiger 5 ; d, unworn heavy spine of setiger 5 ; e, $\mathrm{f}$, bidentate hooded hook and winged capillary neuroseta of setiger 7 ; g,h, posterior hooded hook and unwinged capillary neuroseta; i, posterior notopodial capillaries and specialized awl-shaped spines.

meter. The lower part is rough, rust-coloured, $1.5-3 \mathrm{~mm}$ in diameter. The population density may amount to several thousand individuals per 1 square metre.

The species has been found intertidally at the Small Kurile Archipelago. In Peter the Great Bay it occurs at a depth of $170-210 \mathrm{~m}$. In northern regions it has been found at a depth of 2-10 $\mathrm{m}$.

Nere record. First record for the Aleutian Islands.

Distribution. Arctic Europe and Asia: from Baltic Sea and English Channel to South 
Kurile Islands and Peter the Great Bay, Sea of Japan; western coast of North America: from Aleutian Islands south to San Pedro Channel, southern California; eastern coast of North America: from Hudson Bay south to New England.

\section{Polydora spongicola Berkeley et Berkeley, 1950}

(Figure 10)

Polydora ciliata (Johnston) var. spongicola Berkeley \& Berkeley, 1950, pp. 52-53, fig. 1; 1952, p. 20, fig. 35.

Polydora spongicola: Woodwick, 1963, pp. 212-215, fig. 2. --Hartman, 1969, pp. 149-150, 3 figs. --Hobson \& Banse, 1981, p. 41, fig. 5 o-p.

Polydora uschakovi Buzhinskaja, 1971, pp. 130-132, fig. 3. --Radashevsky, 1988, pp. 870-876, figs 1-4. New synonymy.

?Polydora colonia: Zachs, 1933, p. 129. --Annenkova, 1938, p. 178. --Uschakov, 1955, p. 274. Not Moore, 1907, pp. 199-201, pl. 15: figs 18-23. Not Blake, 1971, pp. 15-16, fig. 10.

Material examined. Polydora ciliata spongicola Berkeley et Berkeley: USNM 32707, Canada, British Columbia, Northumberland Channel, from sponge on shells of Pecten hindsi, 20 paratypes, July 1943, coll. E. \& C. Berkeley. Polydora spongicola: USNM. 135424, Sea of Japan, Vostok Bay, 2 $\mathrm{m}$, from sponge Halichondria panicea, 7 anterior ends, 11 July 1984, coll. V. Radashevsky; NSMTPol. 97637-97638, Sea of Japan, Vostok Bay, 2 m, from sponge, 2 spec., 25 August 1991, coll. V. Radashevsky. Polydora uschakovi: ZISP 1/15181, Sea of Japan, Possjet Bay, boulder bottom, from sponge, holotype, 5 June 1965, coll. A. Golikov; ZISP 2/16837, Sea of Japan, Possjet Bay, from sponge, 1.5-4 m, 2 paratypes, 28 May 1965, coll. A. Golikov; ZISP 3/47439, Sea of Japan, Possjet Bay, boulder bottom, from sponge, $4 \mathrm{~m}, 2$ paratypes, 5 June 1965 , coll. A. Golikov.

Author's collections from Peter the Great Bay and off Tanfiliyev Is., Small Kurile Archipelago; many specimens.

Description. Specimens up to $38 \mathrm{~mm}$ long and $1.5 \mathrm{~mm}$ wide for 110 segments. Body unpigmented but occasionally with dusky pigmentation on pygidium, anterior end, and palps. Prostomium with distinct or weakly developed incision on its anterior margin. Four, occasionally two eyes present, or eyes absent. Caruncle continuing posteriorly to beginning of setiger 3. Nuchal tentacle absent (Fig. 10, a). Palps extending posteriorly for 13-15 segments.

Setiger 1 with only neurosetae, although well developed notopodial lobes present. Winged capillary notosetae of setigers $2-4,6$, and succeeding setigers arranged in three successive rows. Caudally, number of setae per fascicle gradually diminishing, rows of setae becoming indistinct. Specialized posterior notosetae absent. Neuropodial bidentate hooded hooks from setiger 7 , with weak constriction on shaft, up to 12 in series, not accompanied by capillary setae (Fig. 10, e).

Setiger 5 twice as large as neighbouring segments, with row of heavy modified spines alternating with small pennoned companion setae (Fig. 10, c). Dorsal tuft of up to 6 winged setae and ventral tuft of up to 9 winged setae present. Modified spines straight, with subterminal collar extending halfway around spine. One side of collar usually more developed (Fig. 10, d, e).

Branchiae from setiger 7, continuing to near end of body.

Pygidium white coloured, large, cup-shaped, with dorsal incision or small dor- 


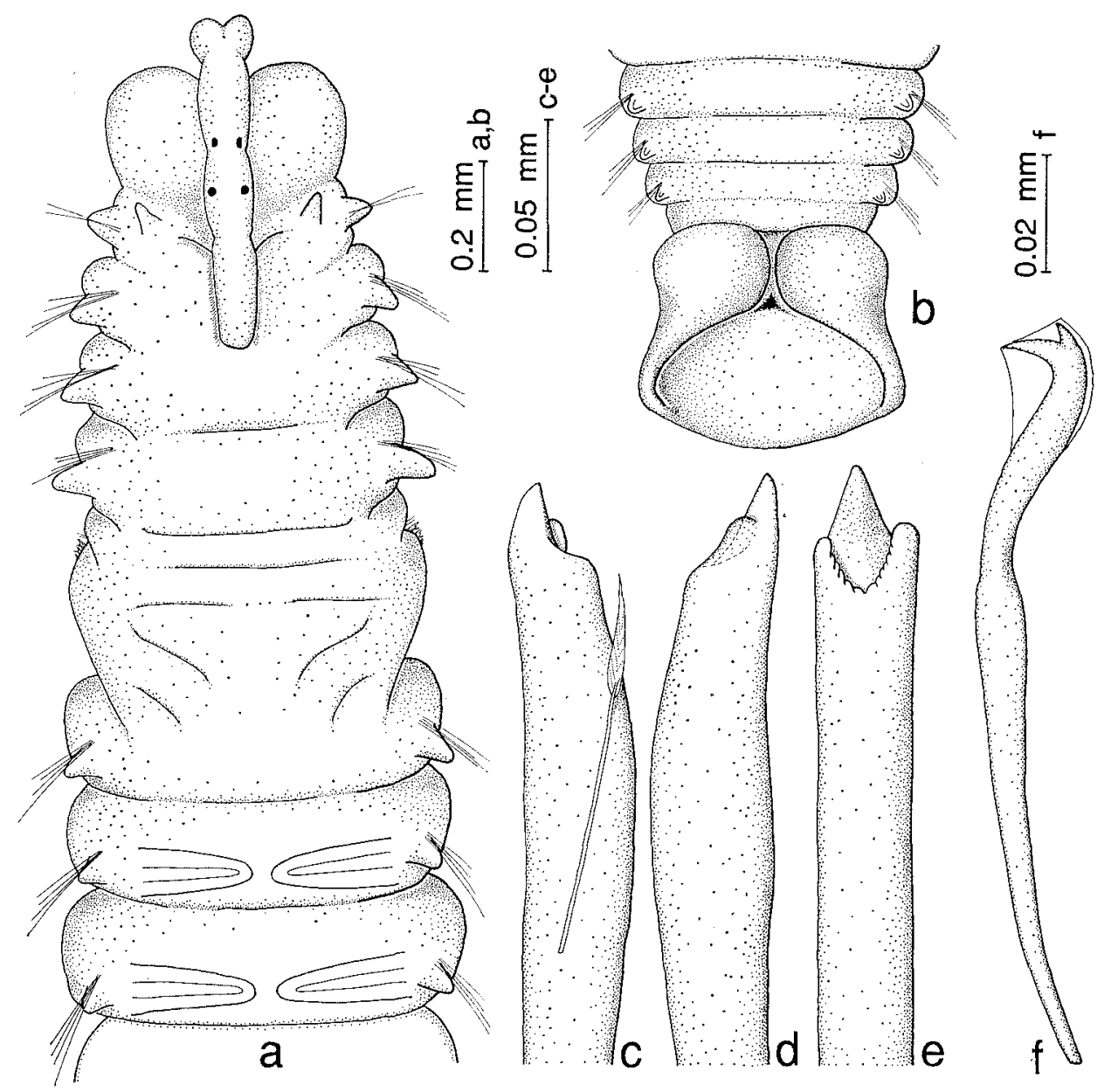

Fig. 10. Polydora spongicola Berkeley et Berkeley. a, anterior end, dorsal view; b, posterior end, dorsal view; c, heavy spine and small companion seta of setiger 5 , right view; d, heavy spine of setiger 5, left view; e, heavy spine of setiger 5 , anterior view; $f$, bidentate hooded hook of setiger 7 .

sal gap, occasionally disc-like (Fig. 10, b).

Glandular pouches from setiger 7, increasingly larger to setigers 10-14 and then diminishing in size.

Gizzard-like structure in digestive tract absent.

Ecology. Polydora spongicola is a borer of sponges. In Peter the Great Bay, the species has been found at a depth of 0.5-25 m in sponges Adocia cinerea (Grant), Halichondria panicea (Pallas) and Ophlithaspongia pennata (Lambe). Near Tanfiliyev Is., it has been found at a depth of $7 \mathrm{~m}$ in a sponge Myxilla incrustans Johnston. It occurs in sponge Lyssodendoryx firma (Lambe) intertidally near Vancouver Is. and in a sponge subtidally off California.

Remarks. The type materials of Polydora uschakovi Buzhinskaja, 1971 and P. spongicola were examined and no differences between them were found. Remarkably, 
there are some discrepanices between the type specimens and their descriptions. The first description of $P$. spongicola made by E. \& C. Berkeley is very short. The latest detailed description of this species was made by Woodwick (1963). He noted that the prostomium in $P$. spongicola is rounded and there are no accessory setae between the heavy spines of setiger 5. Buzhinskaja (1971) reported the absence of accessory setae between the spines and the presence of notosetae on setiger 1 in $P$. uschakovi. However, my observations indicate that in these both species the prostomium has a small anterior incision, the notosetae on setiger 1 are absent, and small pennoned companion setae are present between the heavy spines of setiger 5 . The discrepanices mentioned above were the reason for separation of two species, but now it is evident that $P$. ushakovi should be synonymized with $P$. spongicola.

Zachs (1933) reported P. colonia Moore, 1907 from Peter the Great Bay. Annenkova (1938), Uschakov (1955) and Blake (1971), after Zachs, included this species in the list of polychaetes of the Sea of Japan. Unfortunately, neither description nor figures were given by Zachs and his material is lost. However, $P$. colonia is closely related to $P$. spongicola. Like $P$. spongicola, it inhabits tubes within sponges, but it occurs in the Atlantic only. Therefore, $P$. colonia reported by Zachs apparently should be referred to $P$. spongicola, although this reference may not be defined exactly.

Distribution. Western coast of North America: from Vancouver Is., British Golumbia south to San Pedro, southern California; Peter the Great Bay, Sea of Japan; Small Kurile Archipelago.

\section{Polydora cardalia E. Berkeley, 1927}

(Figures $11 \& 12$ )

Polydora cardalia E. Berkeley, 1927, pp. 418-419, pl. 1, fig. 14. --Berkeley \& Berkeley, 1952, p. 21, figs 38-39. --Pettibone, 1967, p. 11. --Blake, 1979, pp. 609-612, figs 1-2.

Polydora socialis plena Berkeley \& Berkeley, 1936, pp. 468-469; 1952, p. 22. New synonymy.

Polydora flava soederstroemi Annenkova, 1938 (Part.), pp. 177-178, syn., excl. P. flava: Söderström, 1920. --Uschakov, 1955 (Part.), p. 274, syn., excl. P. flava: Söderstörm, 1920, and Okuda, 1937. New synonymy.

Polydora soederstroemi: Annenkova, 1952, p. 126. New synonymy.

Polydora flava: ? Annenkova, 1937, p. 170. --Buzhinskaja, 1967 (Part.), pp. 103-104, syn., excl. Söderstörm, 1920, excl. Okuda, 1937. Not Claparède, 1870, p. 487. Not Söderstörm, 1920, pp. 260-261, Not Okuda, 1937, pp. 228-229, fig. 8. Not Uschakov, 1950, p. 201; 1953, p. 145 ; 1959, p. 205.

Polydora caeca: Uschakov, 1955, p. 274. --Annenkova, 1952, p. 126. Not Oersted, 1843, p. 39. Not Polydora flava orientalis Imajima \& Hartman, 1964, pp. 283-284.

Material examined. Polydora cardalia E. Berkeley: USNM 32708, Canada, British Columbia, Nanaimo, Cardale Point, dredged off Round Island, 19 August 1920, False Narrows, 20 May 1920, Rocky Bay, 17 May 1920, 21 paratypes, coll. E. \& C. Berkeley; ZISP 1/46790, Sea of Japan, Vostok Bay, $8 \mathrm{~m}$, muddy sand, 1 spec., 2 September 1986, coll. V. Radashevsky; ZISP 2/46791, Sea of Japan, Vostok Bay, 8 m, muddy sand, 55 spec., 2 September 1986, coll. V. Radashevsky; ZISP 3/46792, Sea of Japan, Vostok Bay, 10 m, muddy sand, 33 spec., 7 September 1984, coll. V. Radashevsky; ZISP 4/46793, Sea of Japan, Vostok Bay, $10 \mathrm{~m}$, muddy sand, 23 spec., 28 November 1984, coll. V. Radashevsky; IMBV 1/12174, south-eastern Kamchatka, Avacha Inlet, 18 m, 
muddy bottom, 2 spec., 13 June 1984, coll. A. Rzhavsky; IMBV 2/12183, North Bering Sea, North of St. Lawrence Is., "Polar Star", st. 65, 23 m, 2 spec., 18 June 1980; USNM 126515, Sea of Japan, Vostok Bay, 13 m, muddy sand, 41 spec., 17 March 1982, coll. V. Radashevsky; USNM 126516, Sea of Japan, Vostok Bay, $3 \mathrm{~m}$, muddy sand, 40 spec., 1 February 1985, coll. V. Radashevsky; USNM 126517, Sea of Japan, Vostok Bay, 3 m, muddy sand, 5 spec., 14 May 1985, coll. V. Radashevsky; UAMF 1982-1, North Bering Sea, North of St. Lawrence Is., "Polar Star", st. 65, 23 m, 20 spec., 18 June 1980. Polydora socialis plena Berkeley et Berkeley: USNM 32704, Canada, British Columbia, Departure Bay and Piper's Lagoon, Nanaimo District, low tide, clean sand beds, 22 paratypes, 1 and 20 May 1935, coll. E. \& C. Berkeley. Polydora flava soederstroemi Annenkova: ZISP 1/15244, Bering Strait, Dezhnev Cape, $43 \mathrm{~m}$, pebbles, shell debris, syntype, 8 - August 1933, coll. N. Kondakov \& V. Markarov; ZISP 2/37595-8/37601, Sea of Japan, Possjet Bay, 14-21 m, muddy sand, 13-21 July 1962, coll. A. Golikov. Polydora flava: ZISP 2/25695, Bering Sea, Provideniya Inlet, Emma Harbour, 5-8 m, muddy sand, 1 spec., 19 September 1929, coll. P. Uschakov; ZISP 3/25696, Bering Sea, Provideniya Inlet, Emma Harbour, 16 m, muddy bottom, 1 spec., 17 September 1929, coll. P. Uschakov; ZISP 4/25697, Bering Sea, Provideniya Inlet, Emma Harbour, 14-16 m, muddy bottom, many spec., 17 September 1929, coll. P. Uschakov; ZISP 11/7425, Kurile Islands, Paramushir Is., Neprokhodimy Point, 18 m, rocks, 1 spec., 4 August 1954, coll. N. Spirina; ZISP 12/37662-16/37666, Sea of Japan, Possjet Bay, 14-18 m, muddy sand, 1965-1966, coll. A. Golikov. Polydora caeca: ZISP 4/25678, south-eastern Kamchatka, Avacha Inlet, 50-60 m, 7 spec., coll. K. Vinogradov; ZISP 11, Chukotsk Sea, Chukotsk Peninsula, Heart-Stone Point, 67 02' N, $172^{\circ} 00^{\prime}$ W, st. 2, "Krasin", 29 m, muddy sand, 3 spec., 17 July 1935, coll. P. Uschakov; ZISP 12, Chukotsk Sea, Vrangel Is., 24 m, sand, $71^{\circ} 20^{\prime}$ N, $175^{\circ} 36^{\prime}$ W, st. 50, “Krasin”, I spec., 1935, coll. P. Uschakov,

Author's collections from Peter the Great Bay; many specimens.

Description. Specimens found in Peter the Great Bay up to $115 \mathrm{~mm}$ long and 2.0 $\mathrm{mm}$ wide for 250 segments. Large worms obtained intact very seldom. Usually samples containing small specimens or anterior fragments of large specimens of $P$. cardalia. Small specimens with larval black pigment on dorsal side of 15-20 anterior segments (Fig. 11, a). Body pigmentation in largest specimens absent (Fig. 11, b). Prostomium deeply incised on its anterior margin. Specimens, having up to 50 segments, with three pairs of black eyes. Largest specimens usually with four eyes, but occasionally with two or eyes absent. Caruncle in small worms continuing posteriorly to setiger 3, but in larger specimens it extending usually to beginning or occasionally to end of setiger 5. Nuchal tentacle absent. Palps extending posteriorly for 2537 segments.

Setiger 1 with fascicles of capillary setae in both noto- and neuropodia. Anterior notopodial lobes well developed. In large specimens these lobes on setiger 1 overlapping part of setiger 2 and sometimes containing glandular cells. In small specimens anterior notopodial lobes much smaller and never glandular. Setigers 2-4, 6 , and succeeding setigers with large spreading fascicles of winged capillary notosetae arranged in three tiers, notosetae of anterior tier being shorter than those of posterior. Caudally, number of winged capillaries per notopodium gradually diminishing, setae becoming longer and thinner (Fig. 12, a, b). Notopodia in posterior region with needle-like capillaries, besides slender short and long winged capillaries (Fig. 12, c). Needle-like capillaries of same thickness as winged capillaries, protruding considerably through cuticle (Fig. 12, d) and representing specialized setae. Number of needles small at first but gradually increasing up to 30 setae per notopodium in hind 

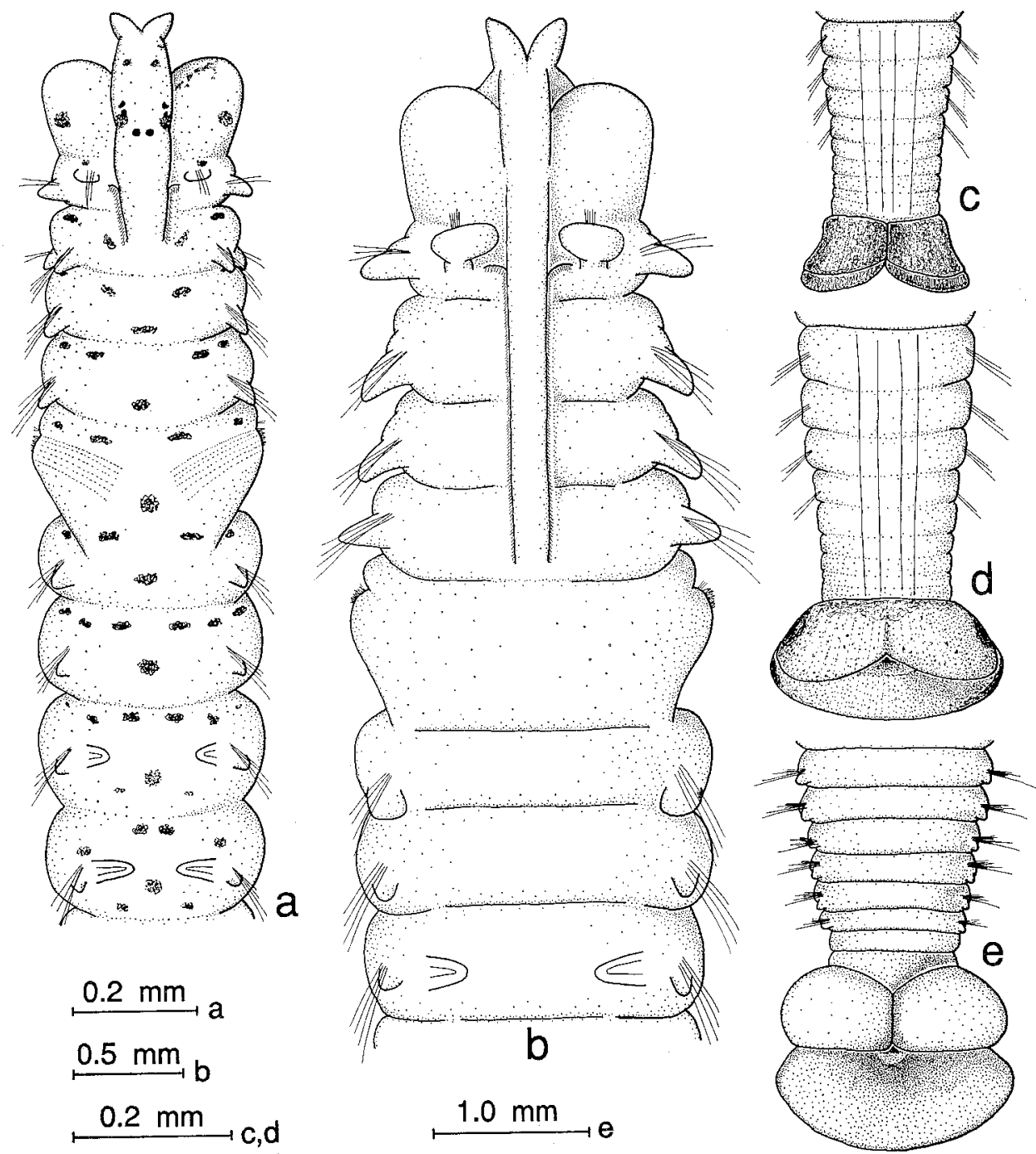

Fig. 11. Polydora cardalia Berkeley. a, anterior end of 32-segmented specimen, dorsal view; $b$, anterior end of 200 -segmented specimen, dorsal view; $c$, posterior end of 32-segmented specimen, dorsal view; d, posterior end of 42-segmented specimen, dorsal view; e, posterior end of 200-segmented specimen, dorsal view.

setigers. Needle-like capillaries not forming tight packets, but distinct. Remarkably, these needles present in large specimens, whereas absent in juveniles.

Neuropodial bidentate hooded hooks from setiger 7 , without constriction on shaft (Fig. 12, e, h), up to 10 in series. Up to 5 winged capillary setae accompanying hooks to setigers 11-25 (Fig. 12, f), then disappearing, and 1-3 unwinged capillaries appearing in posterior setigers (Fig. 12, g). Former capillaries located in tuft below vertical row of hooks whereas latter alternating with hooks.

Setiger 5 modified, with curved row of 12 or more heavy spines, alternating with 


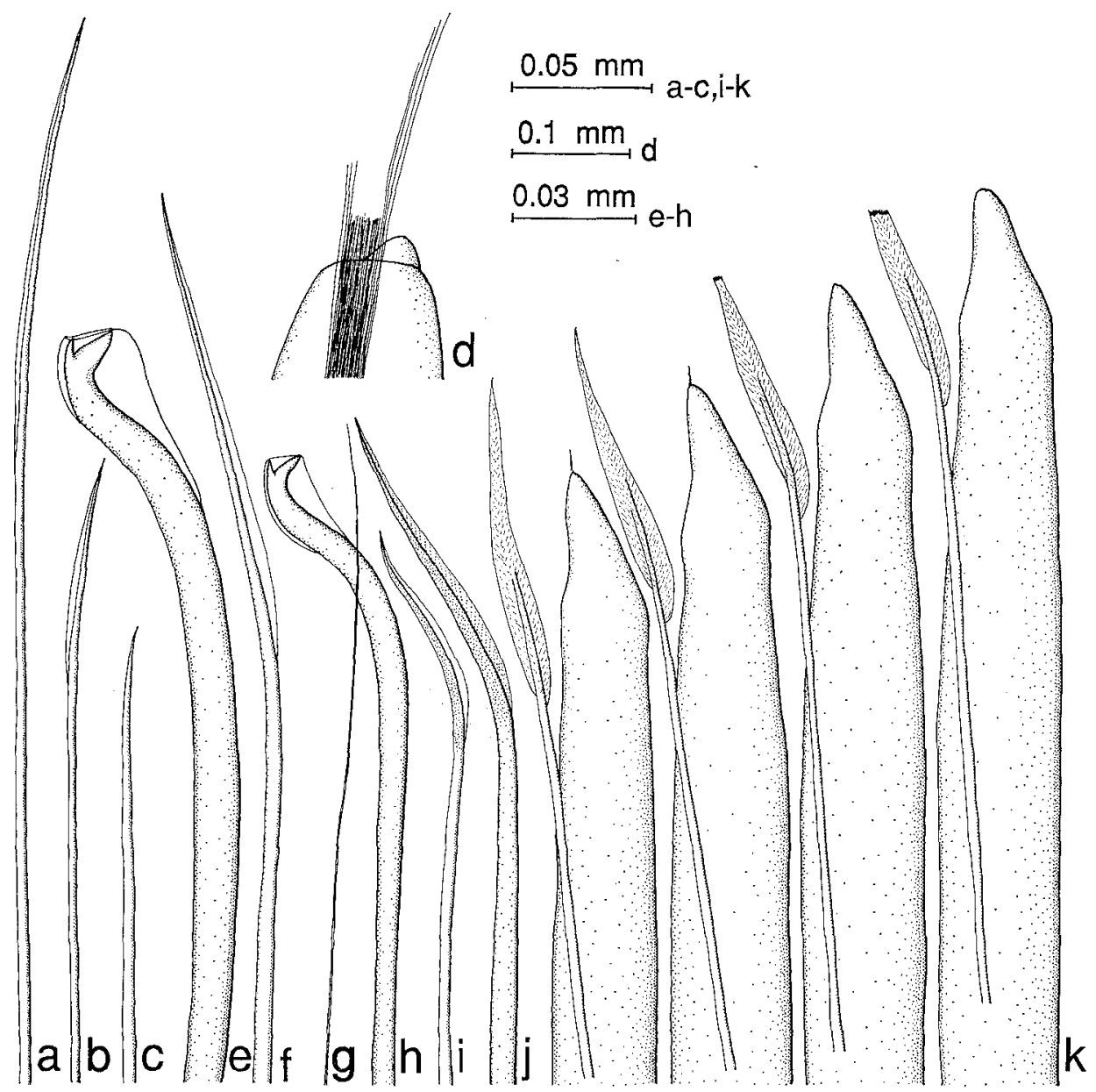

Fig. 12. Polydora cardalia Berkeley, a,b, long and short winged capillaries from posterior notopodia; $\mathrm{c}$, needle-like spine from a posterior notopodium; d, posterior notopodium with capillaries and a tuft of needle-like spines; e, f, bidentate hooded hook and winged capillary neuroseta of setiger $7 ; \mathrm{g}, \mathrm{h}$, posterior unwinged capillary neuroseta and hooded hook; $i$, ventral winged seta of setiger $5 ; j$, dorsal winged seta of setiger $5 ; k$, heavy spines and companion setae of setiger 5 .

bilimbate companion setae (Fig. 12, k). Ventral tuft of up to 17 and dorsal tuft of up to 11 winged setae present (Fig. 12, i,j). Heavy spines generally straight, with poorly developed subterminal enlargement.

Branchiae usually from setiger 8 , but occasionally from setiger 7 or 9 , small at first, attaining full size on setigers 11-16, and absent from posterior one third or one fifth of body.

Pygidium in specimens having up to $40-50$ segments, four-lobed (Fig. 11, c). As animal grew older, two ventral lobes uniting in one and pygidium becoming threelobed (Fig. 11, d). Four-lobed pygidium sometimes retained in specimens having up to 100 segments. Large worms with white, three-lobed pygidium having one 
large ventral lobe and two small dorsal ones (Fig. 11, e).

Glandular pouches from setiger 6, small at first, reaching full size in setiger 10 and diminishing in size after setiger 17.

Gizzard-like structure appearing at first in 30-segmented specimens at level of setigers 11-12 gradually shifting with age; in large specimens, beginning in setigers 27-33 and continuing for three segments.

Ecology. Polydora cardalia constructs tubes usually on muddy substrata. In Peter the Great Bay it has been found subtidally at a depth of 3-63 m. The population density of this species was up to serval ten or hundred individuals per 1 square metre. The size of separate settlements greatly varies from year to year. Remarkably, the juveniles of $P$. cardalia occur more diverse substrata in comparison with adults. Thus, juveniles have been found on sandy and muddy substrata, whereas adults have been found on the muddy substrata only. Moreover, the juveniles of this species may inhabit shallower depth where the adults are absent. Apparently, the larvae of $P$. cardalia have slight ability to select the substrate at settling that causes a great mortality of juveniles with age. In other regions $P$. cardalia inhabits the same conditions.

The tubes of $P$. cardalia are up to $16 \mathrm{~cm}$ in length, and they stand erect in the substrate, projecting $1 \mathrm{~cm}$ above the surface of the bottom. The tubes of large specimens are usually straight, but those of small ones are often branching at the apex. The upper part of the tubes is formed of fine silt, and has a diameter of up to $2.5 \mathrm{~mm}$. The lower part is incrusted with particles of sand and shell fragments, rusty coloured, and has a diameter of up to $4 \mathrm{~mm}$.

Remarks. The large specimens of $P$. cardalia from the Sea of Japan agree in all significant details with the type material of $P$. cardalia from British Columbia. The latter are also large specimens, not less than $1.25 \mathrm{~mm}$ (usually $1.5 \mathrm{~mm}$ ) wide. The redescription of the type material was recently made by Blake (1979), nevertheless some remarks should be done.

Blake noted that $P$. cardalia is unusual in having the fine, scratch-like, subterminal etchings on major spines of setiger 5, exceptionally large, flattened, glandular postsetal lamellae in the notopodia on setiger 1, and in having up to 18 thin needle-like posterior notosetae. However, my observations indicate that these features have individual and age variability: the scratch-like, subterminal etchings on major spines of setiger 5 are not always well developed and occasionally were not observed in some paratypes; the glandular cells in the notopodia on setiger 1 are distinct only in large specimens; the needle-like posterior notosetae, as shown on material from the Sea of Japan, are absent in small specimens. Moreover, paratypes of $P$. cardalia usually have no body pigmentation, but occasionally small transverse pigment bands are present on some anterior segments; up to 30 needle-like notosetae are present in posterior notopodia; branchiae usually begin on setiger 8 , but in two specimens they begin on setiger 7 and in two other specimens on setiger 9, while they are absent on 40-60 hinder setigers; gizzard-like structure begins in setigers 16-23. Thus, the paratypes of $P$. cardalia and the specimens from the Sea of Japan have the same features. 
The paratypes of Polydora socialis plena Berkeley et Berkeley, 1936 from British Columbia were examined. They are small 65- to 80-segmented specimens, not more than $1.12 \mathrm{~mm}$ (usually $0.7-1.0 \mathrm{~mm}$ ) wide. Small size of specimens and well preserved larval pigmentation on anterior setigers suggest that these specimens are juveniles. Remarkably, I have not found differences between paratypes of $P$. socialis plena and small specimens of $P$. cardalia from the Sea of Japan. The paratypes have 12-14 major spines on setiger 5 with the scratch-like etchings. Thus, $P$. socialis plena is here referred to $P$. cardalia.

The worms described by Annenkova $(1938,1952)$ as Polydora flava soederstroemi and Polydora soederstroemi from the Bering Sea (P. flava soederstroemi: ZISP 1/15244; P. flava: ZISP 2/25695, ZISP 3/25696, ZISP 4/25697), and the worms reported by Buzhinskaja (1967) as Polydora flava from Possjet Bay, the Sea of Japan (P. flava: ZISP 12/37662-16/37666; $P$. flava soederstroemi: ZISP 2/37595-8/37601) have been examined and referred to $P$. cardalia.

Polydora flava recorded by Annenkova (1937) from Peter the Great Bay appears to be referred to $P$. cardalia. Unfortunately, this reference may not be exactly defined since Annenkova's material is absent in collections.

The specimens from the Okhotsk Sea reported by Uschakov $(1950,1953,1959)$ as Polydora flava (P. flava: ZISP 5/25698, ZISP 6/25699, ZISP 7) have been examined and turned to be referred neither to $P$. flava nor to $P$. cardalia. They probably belong to some other apparently new species. Thus, Polydora flava Claparède, 1870, is absent from the North Pacific.

The specimens from south-eastern Kamchatka and the Chukotsk Sea reported by Uschakov (1955) and Annenkova (1952) as Polydora caeca (P. caeca: ZISP 4/25678, ZISP 11, ZISP 12) have been examined and referred to $P$. cardalia.

There is one fact of considerable interest in the morphology of $P$. cardalia, that is, a transformation of pygidium with age in juveniles from four-lobed to three-lobed form. This was not previously described in other polydorid species and appears to be a recapitulation. Passing through a four-lobed stage during pygidium formation may indicate a recent evolution of pygidium away from four-lobed form.

New record. First record for the North West Pacific and the Chukotsk Sea.

Distribution. British Columbia; North Bering Sea; Chukotsk Sea; south-eastern Kamchatka; Paramushir Is.; North Japan Sea.

\section{Polydora brevipalpa Zachs, 1933, stat. n.}

(Figures $13 \& 14$ )

Polydora ciliata brevipalpa Zachs, 1933, p. 129.

Polydora ciliata: Okuda, 1937, p. 230, fig. 9, see Imajima \& Sato, 1984. --Imajima \& Hartman, 1964, p. 283. Not Johnston, 1838, p. 67.

Polydora variegata Imajima \& Sato, 1984, pp. 57-62, figs 2-26. --Mori et al., 1985, p. 371. --SatoOkoshi et al., 1990, pp. 61-66. New synonymy.

Material examined. Polydora ciliata brevipalpa Zachs: ZISP 1/25690, Sea of Japan, Peter the Great Bay, dredged off Askold Is., $24 \mathrm{~m}$, from shells, 2 syntypes, 14 June 1926, coll. K. Derjugin. 
Polydora brevipalpa Zachs: ZISP 6/46573, Sea of Japan, Vostok Bay, $5 \mathrm{~m}$, from shell of scallop Mizuhopecten yessoensis, 4 spec., 1 December 1984, coll. V. Radashevsky; ZISP 7/46574, Sea of Japan, Vostok Bay, $5 \mathrm{~m}$, from shells of scallop M. yessoensis, 13 spec., August 1984, coll. V. Radashevsky; ZISP 8/46778, Sea of Japan, Vostok Bay, $10 \mathrm{~m}$, from shells of scallop M. yessoensis, many spec., 9 August 1986, coll. V. Radashevsky; USNM 126520, Sea of Japan, Vostok Bay, $10 \mathrm{~m}$, from shells of scallop $M$. yessoensis, 13 spec., 14 March 1989, coll. V. Radashevsky; NSMT-Pol. 9760097609, Sea of Japan, Vostok Bay, 8 m, from shells of scallop M. yessoensis, 10 spec., 27 May 1990, coll. V. Radashevsky.

Author's collections from Peter the Great Bay; off the Small Kurile Archipelago: Tanfiliyev Is., Anuchin Is.; many specimens.

The Zachs' syntypes have been designated as the lectotype ZISP 1/25690 and the paralectotype ZISP 5/46570 of Polydora brevipalpa. The paralectotype consists of the anterior end with palps, and two middle fragments. A description of the lectotype is given below. All sketches are based on the newly collected specimens since types are not in a good condition.

Description of the lectotype. The lectotype consists of a 37-segmented anterior end with palps and a 35-segmented posterior end with pygidium.

Body pigmentation absent. Prostomium rounded anteriorly. Caruncle continuing posteriorly to middle of setiger 3 . Nuchal tentacle and eyes absent. Palps extending posteriorly for $15-20$ segments, with up to 10 cross black bands.

Setiger 1 with only capillary neurosetae. Specialized spines in posterior notopodia absent. Neuropodial bidentate hooded hooks from setiger 7 , with small constriction on shaft, up to 20 in series, not accompanied by capillaries.

Setiger 5 modified, with row of heavy spines alternating with pennoned companion setae. Ventral tuft of 10 short winged setae present, but no dorsal one. Heavy spines falcate, with lateral flange or sheath, 10 in number.

Branchiae from setiger 7, absent from a few posterior segments.

Pygidium disc-like, thick, with distinct dorsal incision.

Variability. Largest specimens of $P$. brevipalpa found by author measure $53 \mathrm{~mm}$ in length, $1.6 \mathrm{~mm}$ in width on setiger 7 and have up to 170 segments. A characteristic feature of $P$. brevipalpa is the presence of black bands on the palps. It distinguishes the species from others in a sample. Body pigmentation is absent. Black pigments are sometimes scattered around the edge of the pygidium or around the anus. The caruncle extends to the middle of setiger 3 or to the anterior border of setiger 4 . Eyes are absent or present, and, if present, there are four, rarely two (Fig. 13, a). A lateral flange of the heavy spines of setiger 5 occasionally resembles a tooth. Branchiae begin on setiger 7 and continue to near the end of the body, gradually diminishing in size. The pygidium is disc- or cup-like, without dorsal notch, but with a distinct dorsal incision (Fig. 13, b, c). Glandular pouches begin in setiger 7 . They are large in setigers 7-9 and then diminish in size. The gizzard-like structure in the digestive tract is absent.

Remarks. Imajima \& Sato (1984) have described in detail a new species Polydora variegata from Abashiri Bay, Hokkaido. There is not a shadow of doubt about the identity of Japanese material and Zachs' specimens described above. Since the 


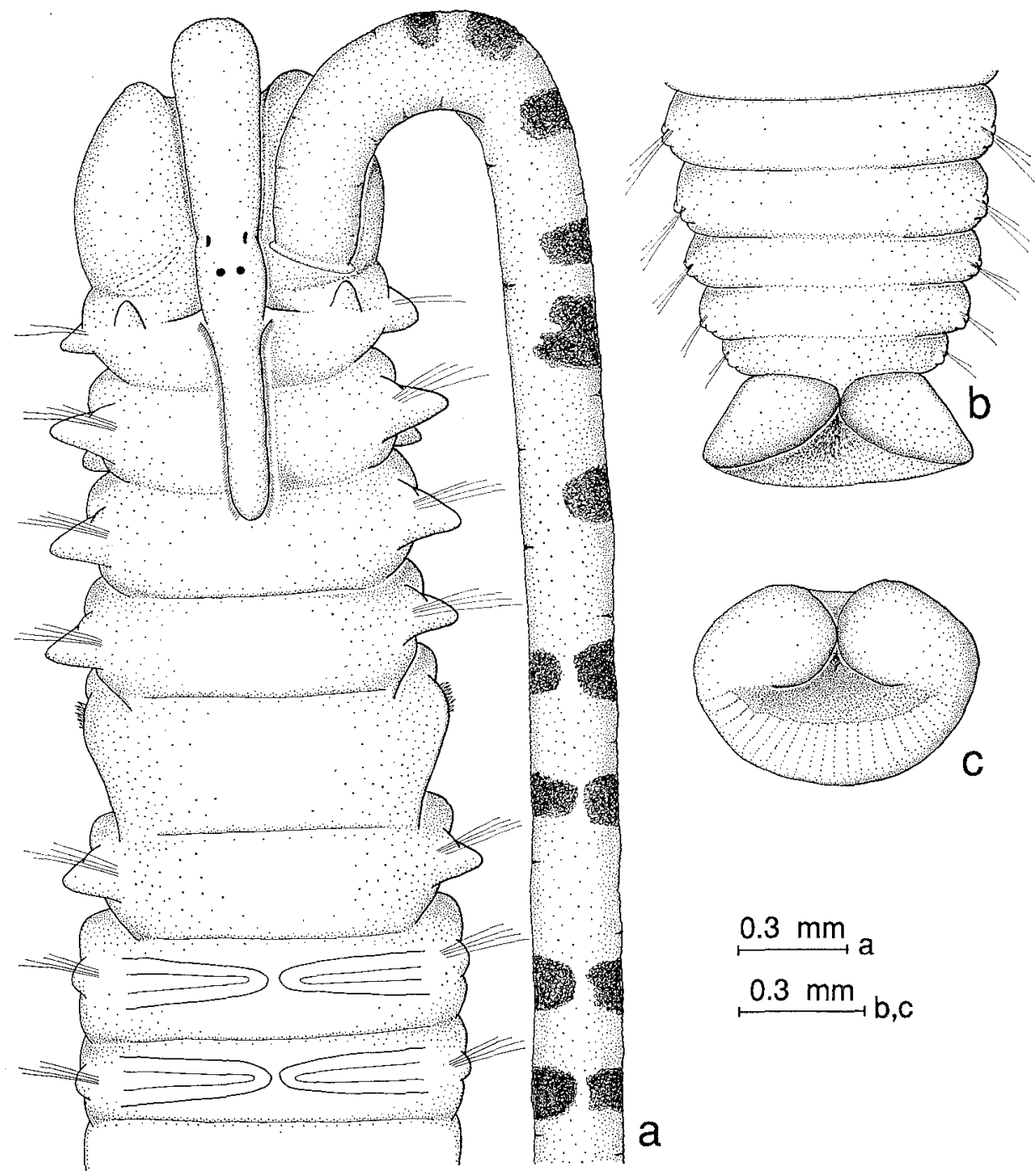

Fig. 13. Polydora brevipalpa Zachs, a, anterior end, dorsal view; b, posterior end, dorsal view; c, pygidium, posterior view.

name brevipalpa proposed by Zachs is available, the valid name of the species is Polydora brevipalpa, and $P$. variegata is a junior synonym.

Ecology. Polydora brevipalpa is known only from shells of a scallop Mizuhopecten yessoensis. It bores branching burrows in the left (upper) valve. The burrows stretch outside the shell as short mud or sand tubes up to $10 \mathrm{~mm}$ high. This species sometimes forms dense aggregations of up to several ten specimens per shell, which damage the scallop valve. P. brevipalpa frequently occurs together with other polydorids. It has been found at a depth of 3-24 m. Imajima \& Sato (1984) and Mori et al. (1985) have collected it at a depth of $30-40 \mathrm{~m}$ also in shells of a scallop M. yessoensis only. 

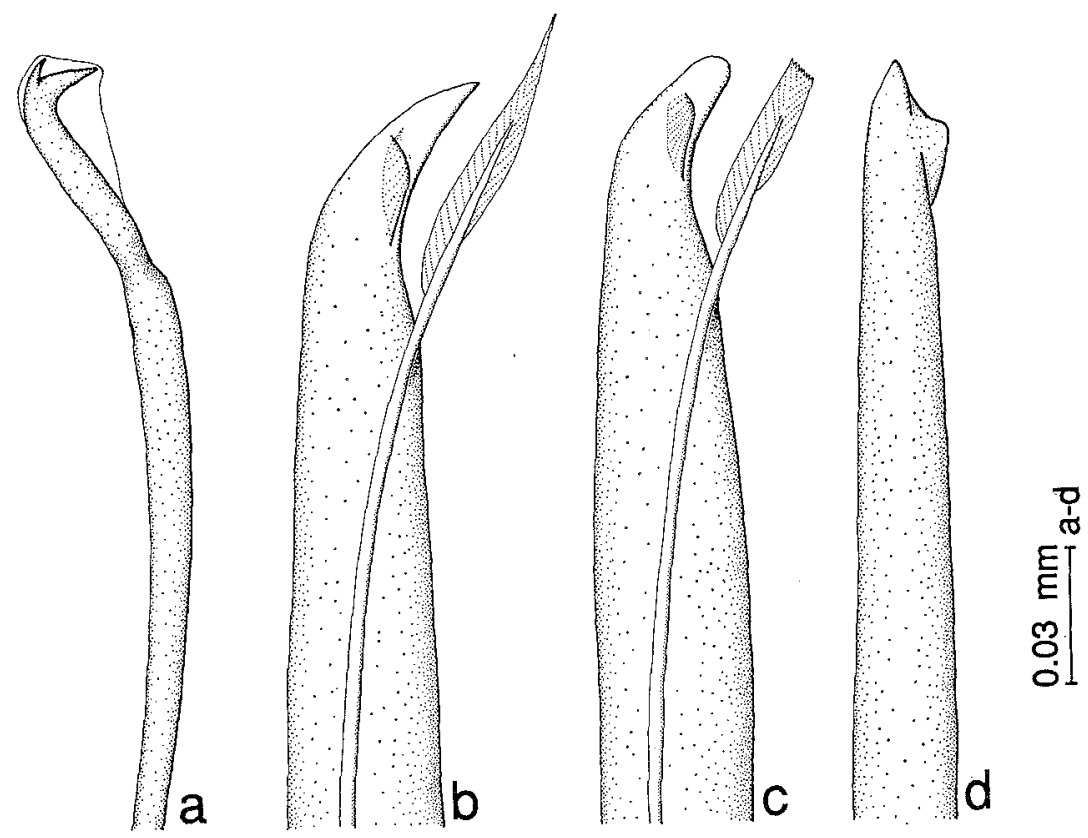

Fig. 14. Polydora brevipalpa Zachs, a, bidentate hooded hook; b, unworn heavy spine and pennoned companion seta of setiger 5 ; $c$, worn heavy spine and companion seta of setiger 5 ; $d$, heavy spine of setiger 5 , posterior view.

New record. First record for the Small Kurile Archipelago.

Distribution. Peter the Great Bay of the Sea of Japan; Okhotsk Sea coast of Hokkaido: Abashiri Bay; Small Kurile Archipelago.

\section{Polydora bidentata Zachs, 1933, stat. n.}

(Figures 15, 16 \& 17 a-d)

Polydora flava bidentata Zachs, 1933, p. 129. --Uschakov, 1955, p. 274.

Polydora flava: Annenkova, 1938, p. 177, fig. 13. --? Greasimov, 1983, p. 123. Not Claparède, 1870 , p. 487. Not Annenkova, 1937, p. 170. Not Uschakov, 1950, p. 201; 1953, p. 145; 1959 , p. 205.

Polydora flava flava: Uschakov, 1955, p. 274, fig. 94, L.

Polydora ciliata possjetica Buzhinskaja, 1971, pp. 127-130, fig. 2. New synonymy.

Polydora convexa Blake \& Woodwick, 1972, pp. 73-74, fig. 1. --Blake, 1980, p. 950. New synonymy. Polydora bidentata: Buzhinskaja, 1985, p. 131.

Not Polydora flava soederstroemi Annenkova, 1938, pp. 177-178.

Material examined. Polydora flava bidentata Zachs: ZISP 1/25702, Sea of Japan, Peter the Great Bay, dredged off Askold Is., 54 m, syntype, 14 September 1926, coll. K. Derjugin; ZISP 2/25703, Sea of Japan, Peter the Great Bay, Ussuriysky Bay, 22-26 m, syntype, 22 June 1926, coll. K. Derjugin. Polydora bidentata: USNM 126519, Sea of Japan, Vostok Bay, $10 \mathrm{~m}$, from shells of scallop M. yessoensis, 50 spec., 5 March 1989, coll. V. Radashevsky; NSMT-Pol. 97590-97599, Sea of Japan, Vostok Bay, $5 \mathrm{~m}$, from shells of scallop $M$. yessoensis, 10 spec., 24 March 1990, coll. V. Radashevsky. IMBV 1/12189, Sea of Japan, Oki Islands, $10-18 \mathrm{~m}$, from crust of coralline alga, 1 spec., 28 July 1992, coll. T. Kato. Polydora flava: ZISP 8/25700, Sea of Japan, Siaukhu Bay, dredged 
off Orekhovy Is., 6-13 m, from old shells, 9 spec., 1 September 1934, coll. E. Gurjanova. Polydora ciliata possjetica Buzhinskaja: ZISP 1/15182, Sea of Japan, Possjet Bay, 6-8 m, on Crenomytilus grayanus under the crust of Lithothamnion sp., holotype, 3 June 1965, coll. A. Golikov. Polydora convexa Blake et Woodwick: USNM 48763, California, Avila, San Luis Obispo Co., intertidal from shell of Pododesmus macrochisma, 2 paratypes, 3 March 1962, coll. K. Woodwick. Polydora ciliata: ZISP 12/25687, Sea of Japan, Siaukhu Bay, Nevodok, from crust of Lithothamnion sp., 2 spec., 2 September 1934, det. N. Annenkova.

Author's collections from off mainland coast of the Sea of Japan from Chikhachev Bay south to East Korean Bay; Moneron Is.; Sakhalin Is.: Pyata Point of Terpeniya Bay, Velikan Point of Tonino-Anivsky Peninsula, Aniva Bay; off islands of the Small Kurile Archipelago; many specimens.

The Zachs' syntypes have been designated as the lectotype ZISP 1/25702 and the paralectotype ZISP $2 / 25703$ of Polydora bidentata. The paralectotype comprises the middle part of the worm's body. A description of the lectotype is given below. However, since Zachs' specimens are poorly preserved and not numerous, all sketches (excluding the heavy spines of setiger 5) are based on author's material, and the description of the species is given separately.

Description of the lectotype. The lectotype consists of a 70-segmented anterior end without palps, a 20-segmented middle part and a 65-segmented posterior fragment with the pygidium missing.

Pigmentation absent. Prostomium deeply notched on its anterior margin. Four eyes present. Caruncle continuing posteriorly to setiger 5. Nuchal tentacle absent.

Setiger 1 with capillary setae in both noto- and neuropodia. After setiger 25, notopodia with long capillary setae and tight packets of needle-like spines. Neuropodial bidentate hooded hooks from setiger 7 , without constriction on shaft. Up to 4 capillary setae accompanying hooks to setiger 12 , then disappearing, and appearing again in far posterior setigers. Up to 8 hooks present in anterior setigers, reducing to 3 posteriorly.

Setiger 5 modified, with curved row of heavy spines alternating with pennoned companion setae. Dorsal tuft of 7 winged setae and ventral tuft of 10 short winged setae present. Heavy spines falcate, with collar on convex side and spoon-like hollow on concave side (Fig. 16, a), nearly 10 in series.

Branchiae from setiger 8 , continuing to setiger 60 , being small at first.

Description of the author's material. Specimens up to $55 \mathrm{~mm}$ long and $1.5 \mathrm{~mm}$ wide for 300 segments. Small 90-segmented worms occasionally with larval melanophores on dorsal side of anterior segments. Larger worms without pigmentation. Prostomium deeply incised or distinctly bifid anteriorly. Two or four eyes present or eyes absent. Caruncle continuing posteriorly to middle of setiger 4 or to setiger 5. Nuchal tentacle absent (Fig. 15, a). Palps extending posteriorly for 15-20 segments.

Setiger 1 with capillary noto- and neurosetae. Notosetae of setigers 2-4, 6, and succeeding setigers arranged in three successive rows. Caudally, number of setae per notopodium gradually diminishing. From setigers 20-30, notopodia with tight packets of needle-like double-edged spines, besides capillaries (Fig. 15, c). The 

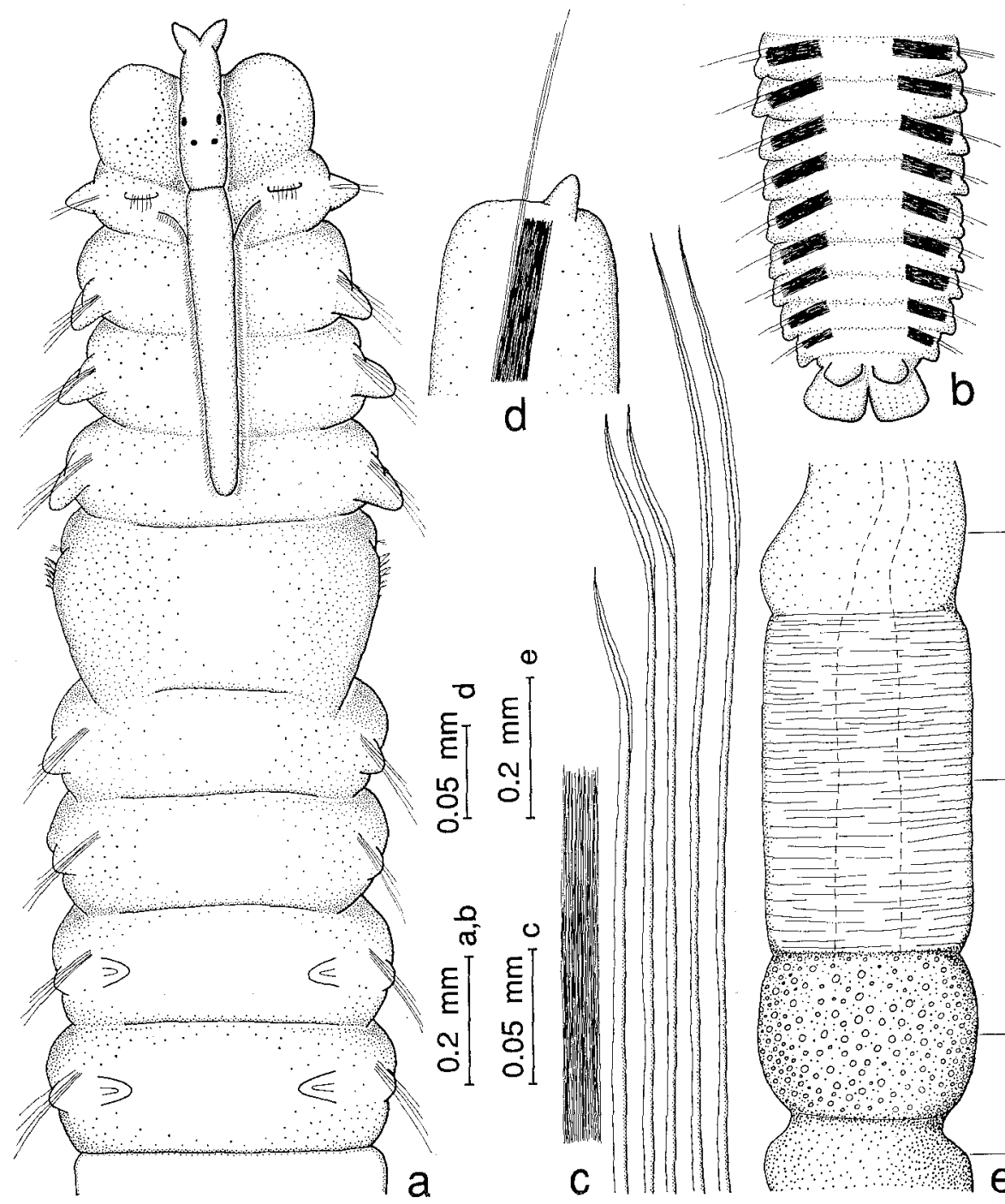

Fig. 15. Polydora bidentata Zachs. a, anterior end, dorsal view; b, posterior end, dorsal view; c, winged capillaries and packet of needle-like spines from notopodium of setiger 30 ; $d$, posterior notopodium with capillaries and packet of needle-like spines; e, gizzard-like structure in the digestive tract, designation the same as in Polydora concharum, see above.

packets not protruding through cuticle (Fig. 15, d), at first small and with short spines, but on succeeding setigers number of spines in packets increasing and spines becoming longer. Needles appearing in definite segment immediately after its formation and not lost with age. Neuropodial bidentate hooded hooks from setiger 7 , without constriction on shaft (Fig. 17, a, c), up to 10 in series. Up to 4 winged capillary setae (Fig. 17, b) accompanying hooks to setigers 11-15, then disappearing, and unwinged capillaries (Fig. 17, d) appearing in posterior setigers. In posterior 


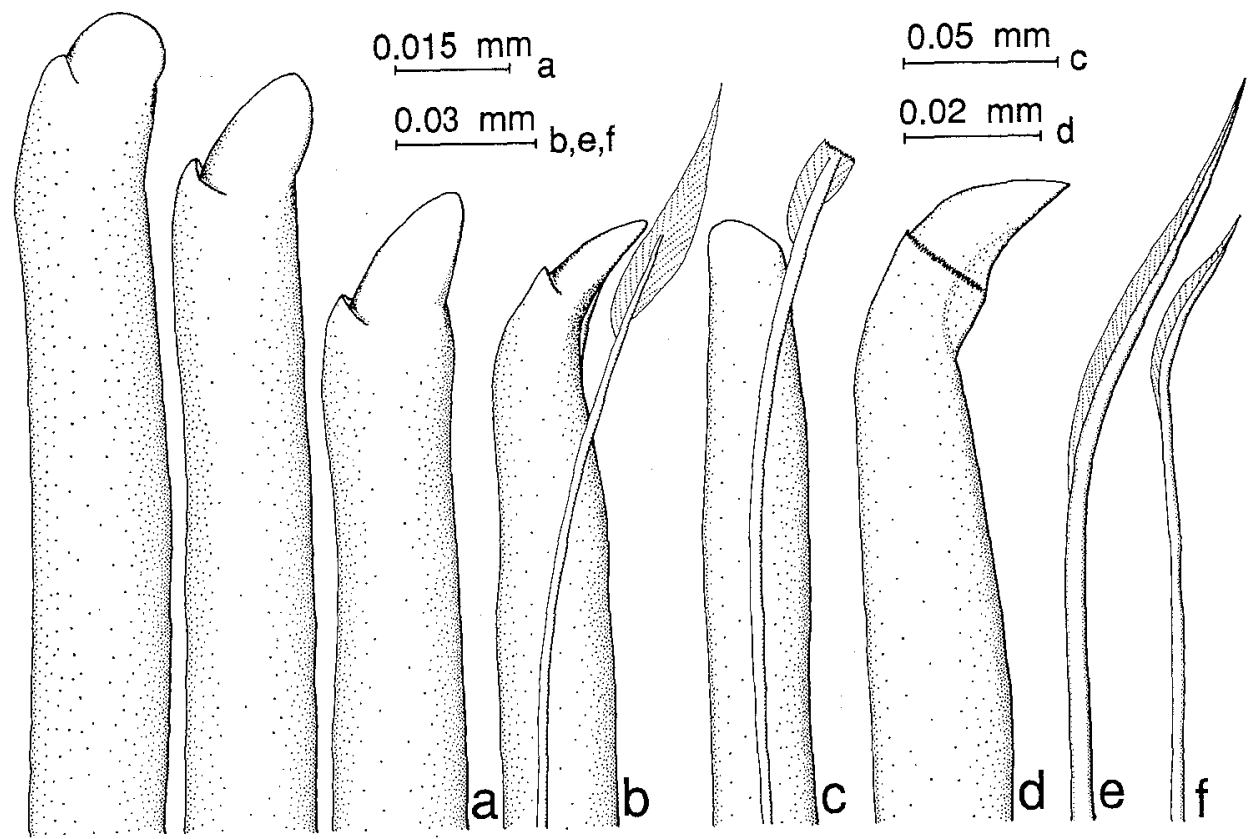

Fig. 16. Polydora bidentata Zachs. a, heavy spines of setiger 5 ; b, unworn heavy spine and pennoned companion seta of setiger 5 ; c, worn heavy spine and companion seta of setiger 5 ; d, heavy spine of setiger 5 ; e, dorsal winged seta of setiger 5 ; f, ventral winged seta of setiger 5 . a -lectotype; b, c, e, f -author's material from Vostok Bay; d -author's material from Yuri Is., the Small Kurile Archipelago.

segments upper tooth of hooks smaller than in anterior ones, closely adhering to main fang (Fig. 17, c).

Setiger 5 modified, with dorsal and ventral tufts of winged setae (Fig. 16, e, f). Heavy spines with collar on convex side and spoon-like hollow on concave side. Collar usually well developed (Fig. 16, b) (in lateral view it may be confused with a small upper accompanying tooth). Occasionally collar surrounding whole of distal end of spine (Fig. 16, d), but sometimes it weakly developed. Heavy spines alternating with pennoned companion setae (Fig. 16, b, c).

Branchiae usually from setiger 8 , but occasionally from setiger 7 or 9 , small at first, attaining full size on setigers 12-14, . Branchiae absent from posterior half or one third of body.

Pygidium small, consisting of two ventral lobes and two smaller dorsal ones, of same colour as body (Fig. 15, b).

Glandular pouches from setiger 6 , small at first, reaching full size in setigers 7-8 and diminishing in size after setigers 10-13.

Gizzard-like structure in digestive tract present (Fig. 15, e), resembling that of $P$. concharum (see above). It continuing for three segments, beginning in setigers 16-25.

Ecology. Polydora bidentata is a borer of various calcareous substrata. It bores 


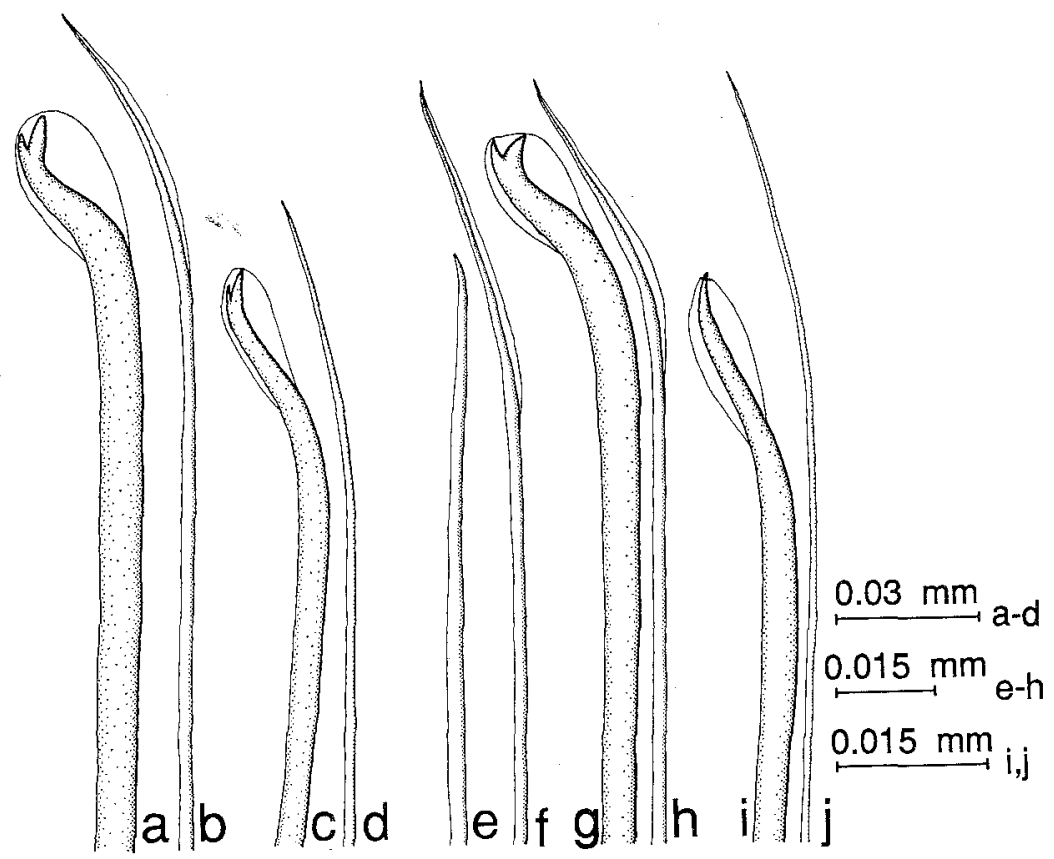

Fig. 17 Polvdora bidentata Zachs. a, b, bidentate hooded hook and winged capillary neuroseta of setiger 7; c, d, posterior hooded hook and unwinged capillary neuroseta.

Polydora trilobata sp. n. e, f, posterior unwinged and winged capillary notosetae; $g, h$, bidentate hooded hook and winged capillary neuroseta of setiger $7 ; \mathrm{i}, \mathrm{j}$, posterior unidentate hooded hook and unwinged capillary neuroseta.

into shells of living gastropods Acmaea pallida (Gould), Tegula rustica (Gmelin), Nucella heyseana, Buccinum middendorffi, Margarites sp., and empty shells of gastropods Tritonalia (Ocenebra) japonica (Dunker), Cryptonatica janthostoma, C. hirasei, C. wakkanaiensis, Lunatia pila, L. pallida, Margarites sp., Nucella heyseana, Neptunea bulbacea occupied by hermit crabs. The species has been found also in shells of an oyster Crassostrea gigas, scallops Mizuhopecten yessoensis, Sreiftopecten swifti (Bernardi), mussels Crenomytilus grayanus (Dunker), Modiolus kurilensis Bernard, a jungle shell Pododesmus macrochisma (Deshayes), and crusts of coralline algae. Near the Small Kurile Archipelago it inhabits also empty shells of a gastropod Fusitriton oregonense (Redfield), occupied by hermit crabs, and empty shells of a bivalve Callista brevisiphonata (Carpenter). Near Shikotan Is. P. bidentata bores also calcareous tubes of serpulids.

The species is common inhabitant of coastal waters. Sometimes it forms dense aggregations, up to some ten worms in one shell. $\quad P$. bidentata occurs at a depth of $1-$ $20 \mathrm{~m}$ usually together with the other polydorids in one shell.

Differential diagnosis. Polydora bidentata resembles Polydora flava Glaparède, 1870. However, in $P$. flava the caruncle extends to setiger 3, packets of needles begin on setiger 8 , the modified spines of setiger 5 have no collar, and the pygidium is usually divided into 3 lobes. Moreover, $P$. flava inhabits tubes in sediment, whereas $P$. bidentata bores into shells. 
Remarks. Since the name bidentata proposed by Zachs is available, the valid name of the species is Polydora bidentata. The worms reported by Annenkova (1938) as Polydora flava ( $P$. flava: ZISP 8/25700) from Siaukhu Bay (now is Preobrazheniya Inlet and Sokolovskaya Bay) have been examined and referred to P. bidentata. This material was reported by Uschakov (1955) as Polydora flava flava.

The type material of Polydora ciliata possjetica Buzhinskaja, 1971 from Possjet Bay has been examined and referred to $P$. bidentata. Referring to the author's personal communication about this reidentification, Buzhinskja (1985) reported P. bidentata from South Sakhalin.

Polydora flava recorded by Gerasimov (1983) from Vostok Bay in shells of a mussel $C$. grayanus appears to be referred to $P$. bidentata. Unfortunately, this reference may not be exactly defined since Gerasimov's material is absent in collections.

The paratypes of Polydora convexa Blake et Woodwick, 1972 from California were examined. No difference between them and P. bidentata have been found. Thus, $P$. convexa is a junior synonym.

Etymology. A broad collar on the convex side of the heavy spines of setiger 5 was described by Zachs as an accompanying tooth. The name of the species is probably derived from this feature.

New record. First record for the Small Kurile Archipelago, Japan and the North East Pacific.

Distribution. Mainland coast of Sea of Japan: from Chikhachev Bay south to East Korean Bay; Moneron Is.; Sakhalin Is.; Small Kurile Archipelago; Oki Islands; western coast of North America: Californian coast: from Santa Barbara south to Eureka, and northern Gulf of California.

\section{Polydora trilobata sp. n.}

(Figures $17 \mathrm{e}-\mathrm{j} \& 18,19)$

Type material. The holotype, ZISP 1/46576, Sea of Japan, Vostok Bay, $5 \mathrm{~m}$, rocky bottom, from shell of oyster Crassostrea gigas, 12 July 1984, coll. V. Radashevsky; 10 paratypes, ZISP 2/46577, Sea of Japan, Vostok Bay, $5 \mathrm{~m}$, rocky bottom, from shell of $C$. gigas, 12 July 1984, coll. V. Radashevsky; 50 paratypes, IMBV 1/12171, Sea of Japan, Vostok Bay, $5 \mathrm{~m}$, rocky botiom, from shells of C. gigas, 3 March 1989, coll. V. Radashevsky.

Representative material. Polydora trilobata: ZISP 3/46578, Sea of Japan, Vostok Bay, 5-6 m, rocky bottom, from shell of C. gigas, 9 spec., 7 September 1984, coll. V. Radashevsky; ZISP 4/48424, Middle Kurile Islands, Yankich Is., Kraternaya Bight, south-western part of the bight, $10 \mathrm{~m}$, from shells of barnacle Balanus rostratus, 15 spec., 30 June 1988, coll. V. Radashevsky; ZISP 5/48425, Middle Kurile Islands, Simushir Is., Broughton Bight, rocky intertidal, from shells of barnacle Semibalanus cariosus, 20 spec., 12 July 1988, coll. V. Radashevsky; ZISP 6/48426, Simushir Is., Broughton Bight, $10 \mathrm{~m}$, from empty shells of gastropod Fusitriton oregonense occupied by Pagurus sp., 10 spec., 12 July 1988, coll. V. Radashevsky; IMBV 2/12173, south-eastern Kamchatka, Avacha Inlet, 6 $11 \mathrm{~m}$, from shells of gastropod $F$. oregonense and of barnacle B. rostratus, 4 spec., 25 July 1983, coll. A. Rzhavsky; IMBV 3/12176, Bering Sea, Kommandor Islands,, Bering Is., Poludennaya Inlet, 5-7 m, boring tubes of serpulid Crucigera zygophora, 11 spec., 12 September 1986, coll. V. Oshurkov; IMBV 4/12187, Sea of Japan, Oki Islands, 10-18 m, from crust of coralline alga, 4 spec., 28 July 1992, coll. T. Kato. Polydora sp.: UAMF 1982-1, Bering Sea, Pribilof Islands, St. Paul Is., 
SW point, Eside reef, 1 spec., 11 June 1976.

Author's collections from off mainland coast of the Sea of Japan from Chikhachev Bay south to East Korean Bay; Moneron Is., Sakhalin Is.: Aniva Bay, Velikan Point of Tonino-Anivsky Peninsula; off islands of the Small Kurile Archipelago; Dobroye Nachalo Bay of Iturup Is.; Broughton Bight of Simushir Is.; Kraternaya Bight of the Ushishir Islands; many specimens.

Description of holotype. Measuring $16 \mathrm{~mm}$ long and $0.5 \mathrm{~mm}$ wide for 100 segments. Pigmentation absent. Prostomium bifurcated. Caruncle continuing posteriorly to end of setiger 3. Nuchal tentacle and eyes absent (Fig. 18, a). Palps extending posteriorly for 18 segments.

Setiger 1 with fascicles of capillary setae in both noto- and neuropodia. Notopodia of setigers 2-4, 6, and succeeding setigers containing three rows of short and long, winged capillary setae. Caudally, number of setae per fascicle gradually diminishing, wings of capillaries being narrow. In posterior segments only two groups of capillaries present, wings remaining in long setae and reduced in short ones (Fig. 17, e, f). Specialized posterior notosetae absent. Neuropodial bidentate hooded hooks from setiger 7 , without constriction on shaft (Fig. 17, g), up to 5 in series. One or two winged capillary setae (Fig. 17, h) accompanying hooks to setiger 9, then disappearing, and up to three unwinged capillaries (Fig. 17, j) appearing in far posterior setigers. Hooks in posterior setigers with reduced apical tooth, in a few hinder segments hooks unidentate (Fig. 17, i).

Setiger 5 about twice size of adjacent segments, with curved row of 6-8 heavy spines alternating with pennoned companion setae (Fig. 19, a, d). Tuft of 5 winged capillary setae (Fig. 19, b) lying below, and tuft of 3 unilimbate setae (Fig. 19, c) lying above heavy spines. Heavy spines falcate, with lateral accessory structure resembling wide tooth or lateral flange on one side (Fig. 19, a), and fine protuberance with rough edge, closely adhering to main fang, on other side (Fig. 19, d).

Branchiae from setiger 9 to setiger 42, small at first, attaining full size on setiger 12.

Pygidium small, cup-like, with one ventral lobe and two small dorsal ones (Fig. 18, c), white colour owing to large number of mucous cells.

Glandular pouches from setiger 6, small at first, reaching full size in setiger 7 and diminishing in size after setigers 10-11.

Gizzard-like structure in digestive tract present, consisting of two small, white, apparently secretory parts, and large transparent muscular part located between them (Fig. 18, d).

Variability. The worms usually have 50-80 segments and measure 6-14 $\mathrm{mm}$ in length. The largest specimens have up to 105 segments. A prostomium is bifurcated or incised anteriorly. A caruncle extends either to the middle of setiger 3 or to the anterior border of setiger 4 . Small worms have two eyes, but large specimens have none. A wide lateral tooth or flange on the heavy spines of setiger 5 is well developed, while a thin protuberance is sometimes weakly developed. Branchiae usually begin on setigers 8-9, occasionally on setiger 10 or rarely on setiger 7 . They are absent from the posterior half or one third of the body. As a rule, specimens have a 

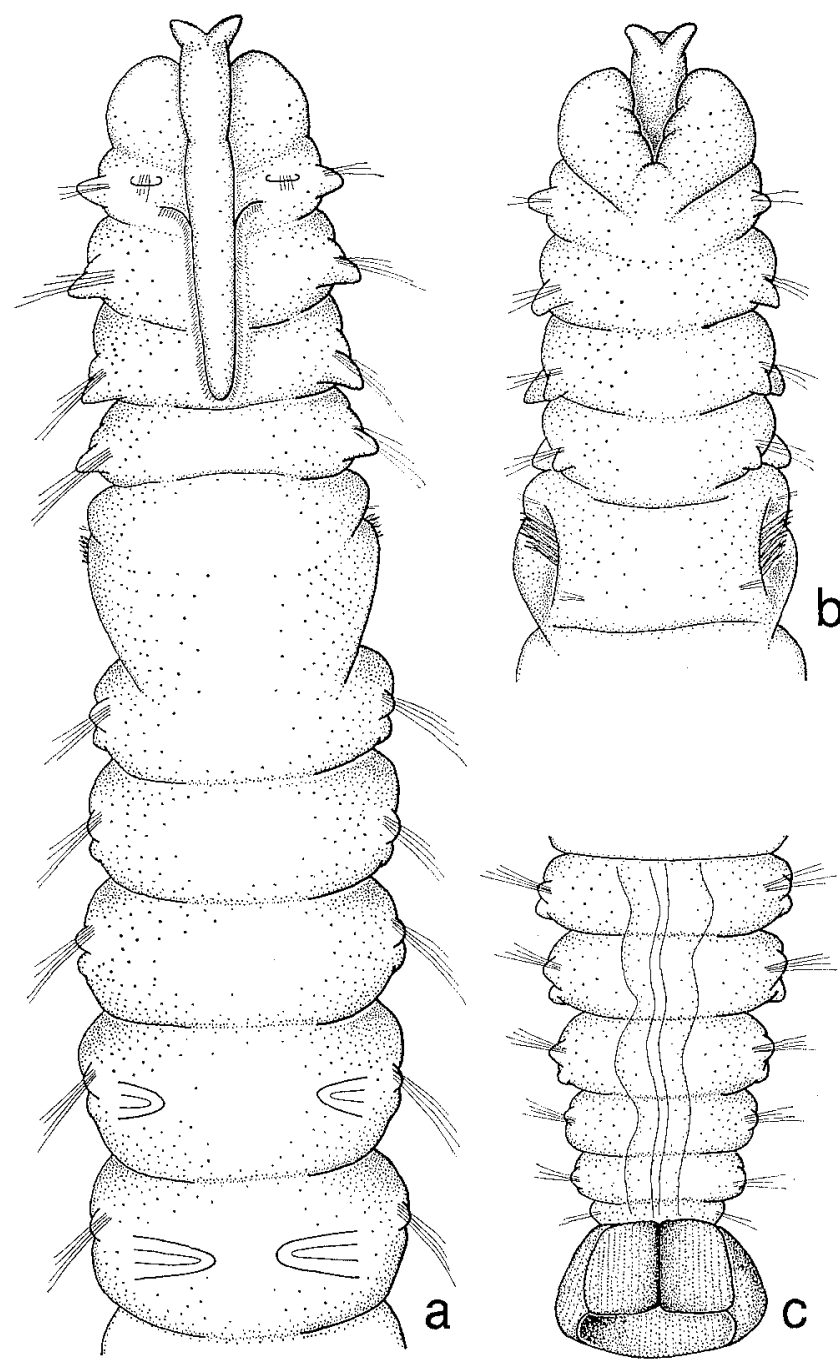
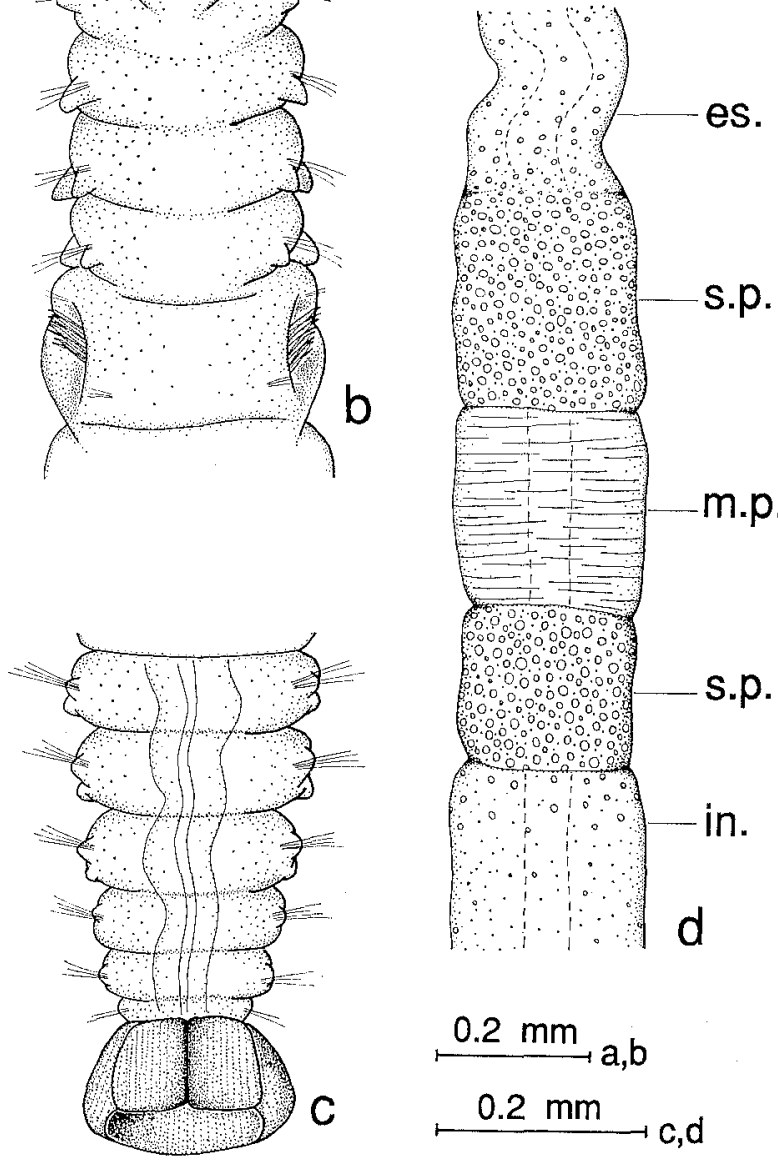

Fig. 18. Polydora trilobata sp. n. a, anterior end, dorsal view; b, anterior end, ventral view; c, posterior end, dorsal view; d, gizzard-like structure in the digestive tract, designation the same as in Polydora concharum, see above.

number of large mucous cells of white colour on the dorsal side, beginning on setigers 8-10. A gizzard-like structure continues for two or three segments, beginning in setigers 13-25.

Ecology. Polydora trilobata is a borer of various calcareous substrata. It has been found at a depth of 1-20 m in shells of an oyster Crassostrea gigas, mussels Crenomytilus grayanus, Modiolus kurilensis, jungle shell Pododesmus macroshisma, in shells of living gastropods Acmaea pallida, Nucella heyseana, Margarites sp., and empty shells of gastropods Buccinum middendorffi, Fusitriton oregonense, Boreotrophon candelabrum, Nucella heyseana, Margarites sp. occupied by hermit crabs. It bores also into crusts of coralline algae and calcareous tubes of serpulids. In Avacha Inlet, south-eastern Kamchatka and 


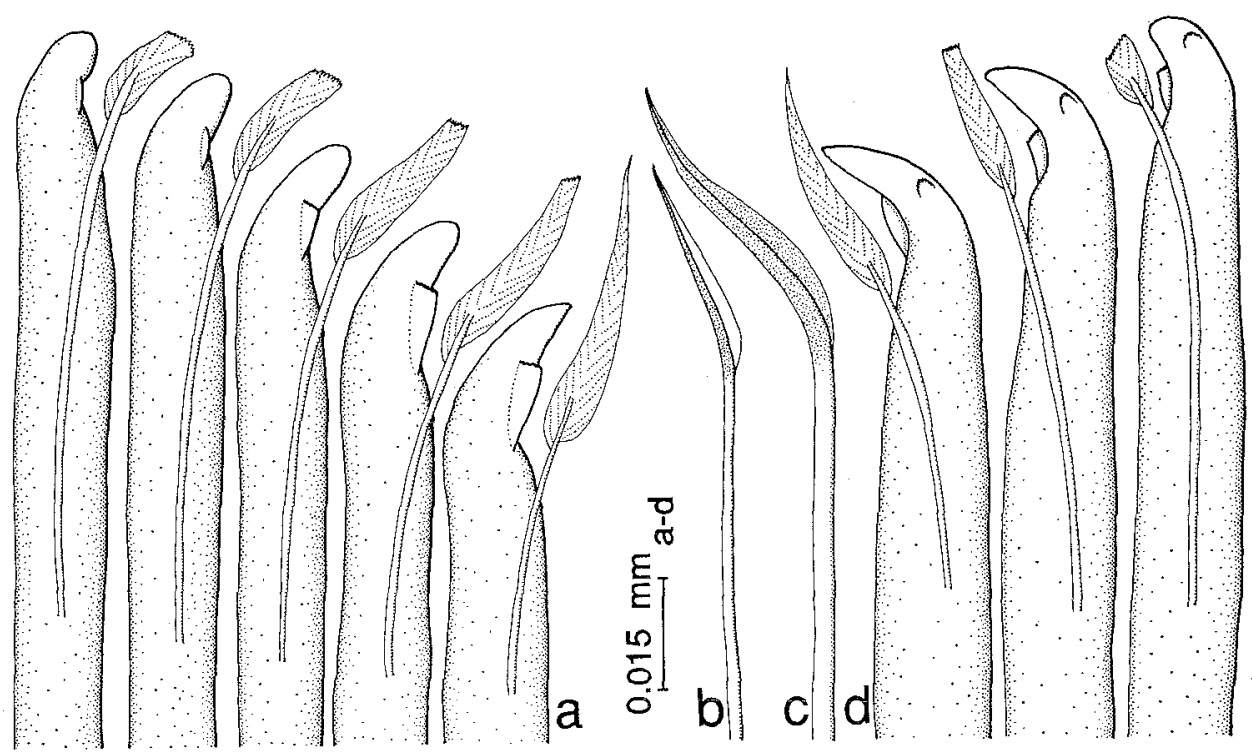

Fig. 19. Polydora trilobata sp. n. a, heavy spines and pennoned companion setae of setiger 5, right view; $b$, ventral winged capillary seta of setiger 5; $c$, dorsal unilimbate capillary seta of setiger 5 ; d, heavy spines and pennoned companion setae of setiger 5 , left view.

in Kraternaya Bight, Ushishir Islands, $P$. trilobata bores shells of a barnacle Balanus rostratus Hoek at a depth of 4-11 m. In Broughton Bight, Simushir Is., it occurs intertidally in shells of a barnacle Semibalanus cariosus (Pallas).

The burrows of $P$. trilobata extend outside the substrate into short mud tubes up to $7 \mathrm{~mm}$ high. The wall of burrows is lined with silt. The species is rather rare, but occasionally several hundred worms are found in one shell of oyster $C$. gigas and mussel $C$. grayanus, giving shells a brushy appearance.

Differential diagnosis. Polydora trilobata resembles $P$. alborectalis (see below). However, it differs from the latter in the length of the caruncle, in form of heavy spines and the pygidium, in colour of the rectum.

Etymology. The epithet is suggested by the form of the pygidium.

Distribution. Mainland coast of the Sea of Japan: from Chikhachev Bay south to East Korean Bay; South Sakhalin; Oki Islands; Kurile Islands: Small Kurile Archipelago, Iturup Is., Simushir Is., Ushishir Islands; south-eastern Kamchatka; Bering Sea.

\section{Polydora alborectalis sp. n.}

(Figures $20 \& 21$ )

PPolydora ciliata possjetica: Gerasimov, 1983, p. 123. Not Buzhinskaja, 1971.

Type materiai. The holotype, ZISP 1/46568, Sea of Japan, Vostok Bay, $5 \mathrm{~m}$, rocky bottom, from shell of mussel Crenomvitus grayanus, 1 March 1984, coll. V. Radashevsky; 10 paratypes, ZISP 2/46569, Sea of Japan, Vostok Bay, $5 \mathrm{~m}$, rocky bottom, from shell of mussel C. grayanus, 1 March 1984, 
cull. V. Radashevsky; 50 paratypes, IMBV 1/12170, Sea of Japan, Vostok Bay, 5 m, rocky bottom, from shell of mussel C. grayanus, 4 March 1989, coll. V. Radashevsky.

Representative material. Polydora alborectalis: ZISP 3/46579, Sea of Japan, Peter the Great Bay, Vityaz Inlet, $6 \mathrm{~m}$, from shells of scallop Mizuhopecten yessoensis, 27 spec., 15 September 1984, coll. V. Radashevsky; ZISP 4/46580, Sea of Japan, Vostok Bay, $5 \mathrm{~m}$, rocky bottom, from shells of mussel $C$. grayanus, 66 spec., 1 March 1984, coll. V. Radashevsky; IMBV 2/12175, south-eastern Kamchatka, Avacha Inlet, 6-11 m, from shells of gastropod Fusitriton oregonense and of barnacle Balanus rostratus, 35 spec., 25 July 1983, coll. A. Rzhavsky; IMBV 3/12186, Simushir Is., Broughton Bight, $15 \mathrm{~m}$, from shell of jingle shell Pododesmus marcrochisma (Deshayes), 6 spec., 12 July 1988, coll. V. Radashevsky. Polydora sp.: UAMF 1972-1, Bering Sea, Pribilof Islands, St. Paul Is., SW point, Eside reef, 11 June 1976, 9 spec.

Author's collections from off mainland coast of the Sea of Japan form Chikhachev Bay south to Peter the Great Bay; Moneron Is.; Sakhalin Is.: Pyata Point of Terpeniya Bay, Velikan Point of Tonino-Anivsky Peninsula, Aniva Bay; off islands of the Small Kurile Archipelago; Izmeny Bay of Kunashir Is.; Prostor Bay and Dobroye Nachalo Bay both of Iturup Is.; Broughton Bight of Simushir Is.; North Okhotsk Sea: Zabiyaka Bay, Yamskiye Islands of Shelikhov Bay; southeastern Kamchatka: Avacha Inlet; many specimens.

Description of holotype. Measuring $20 \mathrm{~mm}$ long and $0.36 \mathrm{~mm}$ wide for 145 segments. Pigmentation absent. Prostomium incised on anterior margin. Caruncle continuing to anterior border of setiger 3. Nuchal tentacle and eyes absent (Fig. 20, a, b). Palps extending posteriorly for 20 segments.

Setiger 1 with capillary noto- and neurosetae. Notosetae of setigers $2-4,6$, and succeeding setigers arranged in three successive rows. Caudally, number of setae per notopodial fascicle gradually diminishing, capillaries of anterior row lacking wings (Fig. 21, a). Specialized posterior notosetae absent. Winged capillary neurosetae of setigers 1-4, and 6 arranged in two rows. Neuropodial bidentate hooded hooks from setiger 7, without constriction on shaft (Fig. 21, c, e), up to 6 in series. One or two winged capillary setae (Fig. 21, d) accompanying hooks to setiger 10, then disappearing, and up to four unwinged capillaries (Fig. 21, f) appearing in posterior setigers.

Setiger 5 modified, with semicircular row of heavy spines alternating with pennoned companion setae (Fig. 21, i, j). Dorsal tuft of 4 winged setae (Fig. 21, g) and ventral tuft of 6 winged setae (Fig. 21, h) present. Heavy spines falcate, with spoonlike hollow on concave side and weakly developed accessory shelf on convex side, 7 in number.

Branchiae from setiger 9 to setiger 90 , small at first, attaining full size on setiger 14.

Pygidium small, with four lobes, dorsal pair being smaller than ventral one (Fig. $20, c, d)$, white colour owing to large number of mucous cells.

Glandular pouches from setiger 6, small at first, attaining full size in setiger 7 and diminishing in size after setigers 10-11.

Gizzard-like structure in digestive tract present (Fig. 20, f). Distal part of rectum white colour in life.

Variability. The largest specimens have up to 180 segments and measure $38 \mathrm{~mm}$ in length. Pigmentation is commonly absent, however, the worms inhabiting coralline algae may have a rust-coloured body. Eyes are absent and the caruncle extends 


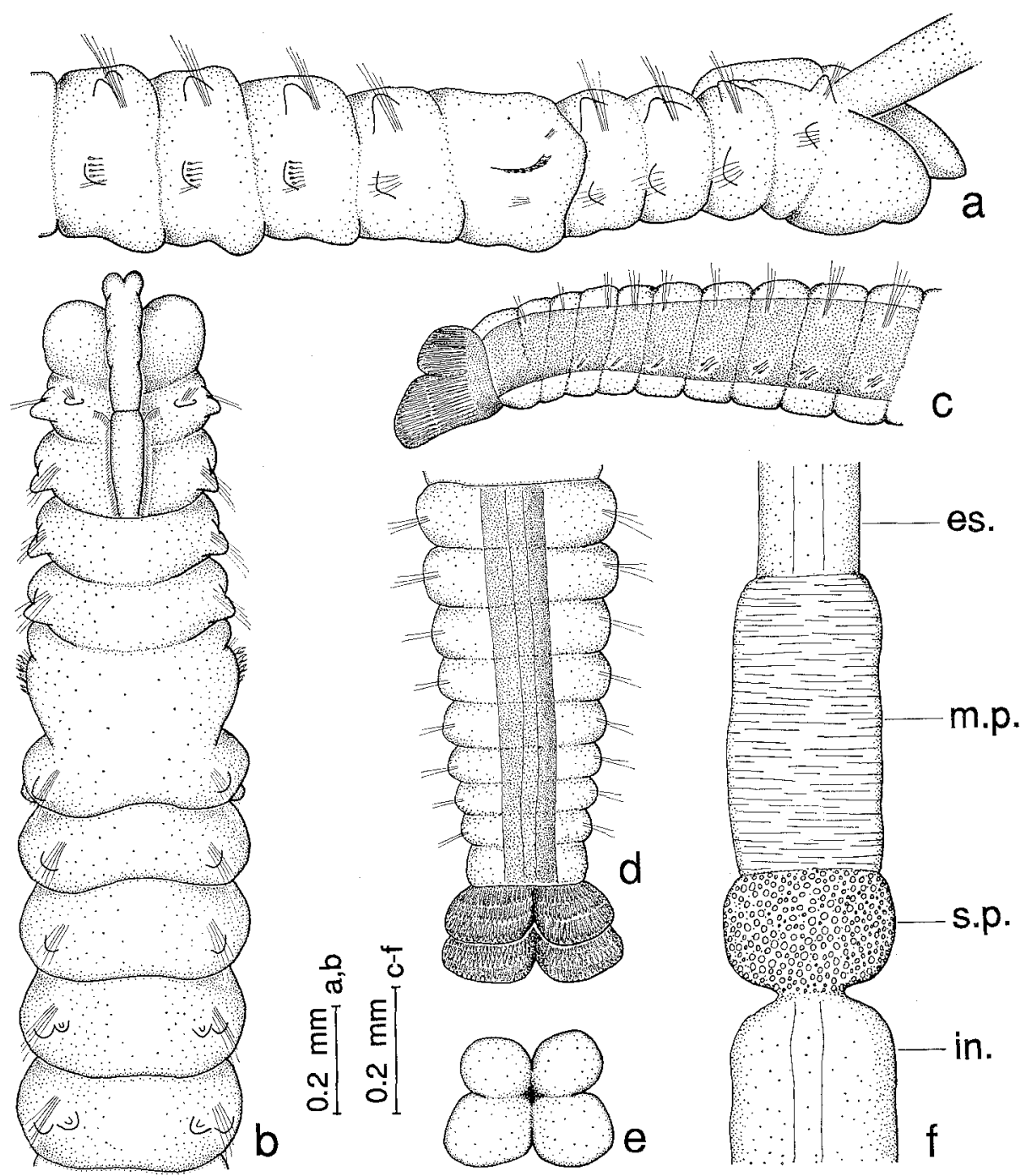

Fig. 20. Polydora alborectalis sp. n. a, anterior end, lateral view; b, anterior end, dorsal view; c, posterior end, lateral view; $d$, posterior end, dorsal view; e, pygidium, posterior view; $\mathrm{f}$, gizzard-like structure in the digestive tract, designation the same as in Polydora concharum, see above.

to setiger 3 in all specimens examined. The heavy spines of setiger 5 have a weakly developed accessory shelf on the convex side, and occasionally, the shelf is absent (Fig. 21, k). Branchiae begin on setiger 9 or on setiger 10, and are absent from the posterior one third of the body. The gizzard-like structure continues for two segments, beginning in setigers 16-21. As a rule, the rectum is clearly white in posterior 5-20 setigers. Occasionally, white colour is weakly developed. The colour of the rectum is a distinguishing characteristic of $P$. alborectalis. Unfortunately, it is visible only on the living material. 


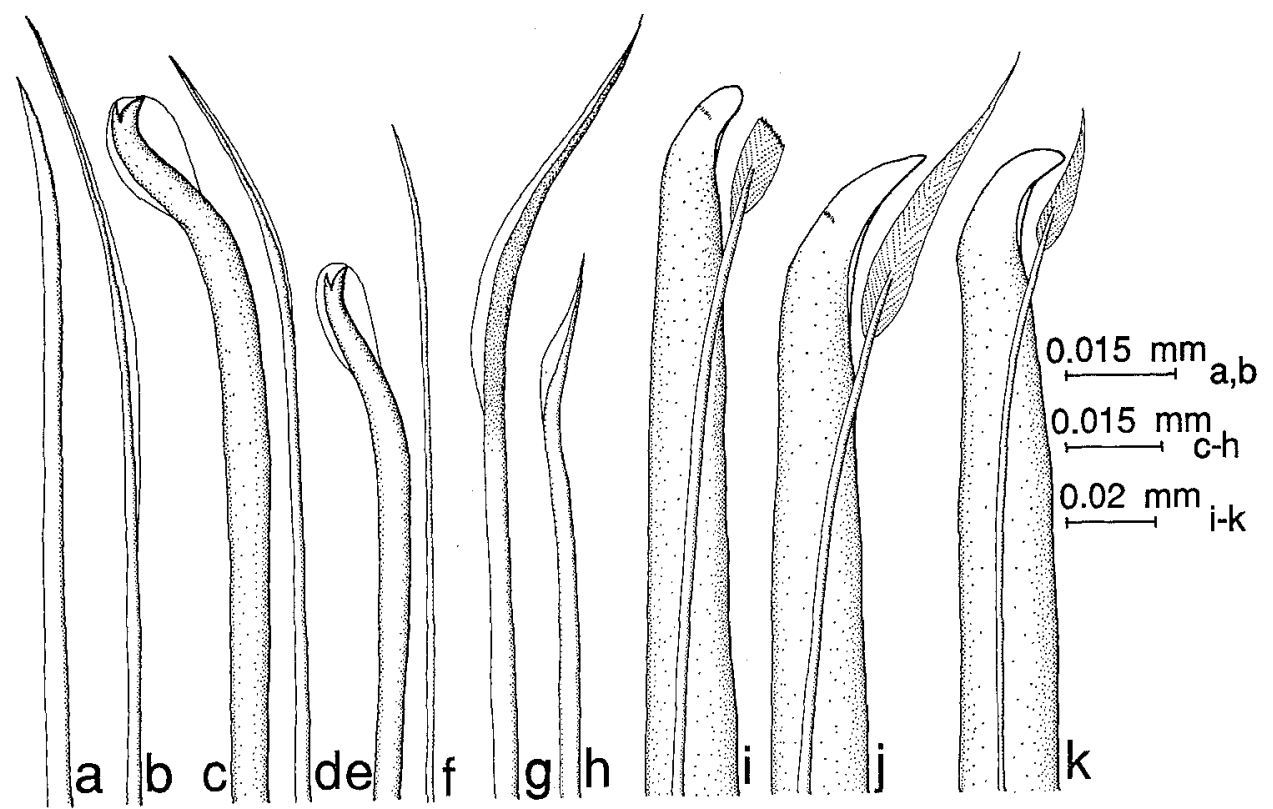

Fig. 21. Polydora alborectalis sp. n. a, b, posterior unwinged and winged capillary notosetae; $\mathrm{c}, \mathrm{d}$, bidentate hooded hook and winged capillary neuroseta of setiger 7; e, f, posterior hooded hook and unwinged capillary neuroseta; $\mathrm{g}$, dorsal winged seta of setiger 5 ; $h$, ventral winged seta of setiger 5 ;, worn heavy spine and pennoned companion seta of setiger $5 ; \mathrm{j}$, unworn heavy spine and companion seta of setiger $5 ; \mathrm{k}$, heavy spine and companion seta of setiger 5 . a-j-type material from Vostok Bay; $k$-material from Shikotan Is., the Small Kurile Archipelago.

Ecology. Polydora alborectalis is a borer of various calcareous substrata. It has been found boring into shells of living gastropods Acmaea pallida, Tegula rustica, Nucella heyseana, Crepidula derjugini, and empty shells of gastropods Cryptonatica janthostoma, Nucella heyseana, Neptunea bulbacea, Fusitriton oregonense occupied by hermit crabs. The species bores also into shells of a mussel Crenomytilus grayanus, a scallop Mizuhopecten yessoensis, Swiftopecten swifti, an oyster Crassostrea gigas, a jingle shell Pododesmus macrochisma, and crusts of coralline algae. In Avacha Inlet, $P$. alborectalis has been found boring into shells of a barnacle Balanus rostratus.

Several hundred worms frequently occur in one shell of $C$. grayanus in Peter the Great Bay. Up to 1500 worms occur in one left (upper) valve of $M$. yessoensis near the Small Kurile Archipelago. The density of settlement reaches to 25 individuals per 1 square centimetre of the valve. The burrows of the worms extend outside the substrate as short mud tubes up to $10 \mathrm{~mm}$ high, which gives the shells brushy appearance. P. alborectalis occurs commonly at a depth of $1-20 \mathrm{~m}$, but in Vostok Bay it was once dredged from $50 \mathrm{~m}$. Near Shikotan Is., it inhabits also shells of intertidal gastropod Littorina squalida.

Differential diagnosis. Polydora alborectalis resembles Polydora concharum Verrill, but differs from it in the smaller size, in having a shorter caruncle and in position of branchiae. It is related to Polydora flava described by Söderström (1920) and Okuda 
(1937) from Japan (not P. flava Claparède, 1870) and redescribed by Imajima \& Hartman (1964) as Polydora flava orientalis. However, in P. flava orientalis, the branchiae begin to appear on setigers 7-9 and continue posteriorly to the caudal portion, and the pygidium is disc-like and has a deep dorsal notch. Furthermore, $P$. flava orientalis inhabits sandy tubes attached to rocks, whereas $P$. alborectalis is a borer.

$P$. alborectalis is related also to $P$. trilobata (see above). It differs from the latter in having pygidium with four lobes, instead of three, in shorter caruncle, in form of the spines and in colour of the rectum.

Remarks. Polydora ciliata possjetica recorded by Gerasimov (1983) from Vostok Bay in shells of a mussel $C$. grayanus appears to be referred to $P$. alborectalis. Unfortunately, this reference may not be exactly defined since Gerasimov's material is absent in collections.

Etymology. The epithet is derived from the white colour of the rectum.

Distribution. Mainland coast of the Sea of Japan: from Chikhachev Bay south to Peter the Great Bay; Moneron Is.; Sakhalin Is.; Kurile Islands: Small Kurile Archipelago, Kunashir Is., Iturup Is., Simushir Is.; North Okhotsk Sea; south-eastern Kamchatka; Bering Sea.

\section{Polydora carunculata sp. n.}

(Figures 22-24)

Type material. The holotype, ZISP 1/46786, Sea of Japan, Vostok Bay, $3 \mathrm{~m}$, sandy bottom, from shell of scallop Mizuhopecten yessoensis, 23 January 1985, coll. V. Radashevsky; 1 paratype, ZISP 2/46787, Sea of Japan, Vostok Bay, $5 \mathrm{~m}$, from shell of scallop M. yessoensis, 27 January 1983, coll. V. Radashevsky; 1 paratype, ZISP 3/46788, Sea of Japan, Vostok Bay, $5 \mathrm{~m}$, from shell of gastropod Acmaea pallida, 1 March 1984, coll. V. Radashevsky; 19 paratypes, ZISP 4/46789, Sea of Japan, Nakhodka Bay, $10 \mathrm{~m}$, sponge Haiichondria panices, 7 August 1986, coll. V. Radashevsky; 1 paratype, ZMMU P1 627, Sea of Japan, Vostok Pay, $3 \mathrm{~m}$, from shell of gastropod Cryptonatica janthostoma occupied by Pagurus capillatus, 14 August 1984, coll. V. Radashevsky; 1 paratype, ZMMU P1 628, Sea of Japan, Vostok Bay, $8 \mathrm{~m}$, from shell of scallop M. yessoensis, 13 January 1985, coll. V. Radashevsky; 1 paratype, ZMMU P1 629, Sea of Japan, Vostok Bay, $8 \mathrm{~m}$, from shell of mussel C. grayanus, 2 September 1986, coll. V. Radashevsky; 1 paratype, ZMMU P1 630, Sea of Japan, Nakhodka Bay, $10 \mathrm{~m}$, from sponge $H$. panicea, 7 August 1986, coll. V. Radashevsky; 18 paratypes, IMBV 1/12169, Sea of Japan, Vostok Bay, $8 \mathrm{~m}$, from shells of scallop $M$. yessoensis, 15 March 1989 , coll. V. Radashevsky.

Representative material. IMBV 2/12188, Sea of Japan, Oki Islands, 10-18 m, from crust of coralline alga, a juvenile specimen mounted on a slide, 28 July 1992, coll. T. Kato.

Author's collections from off mainland coast of the Sea of Japan from Chikhachev Bay south to East Korean Bay; Moneron Is.; Small Kurile Archipelago; Polonsky Is.; many specimens.

Description of holotype. Measuring $54 \mathrm{~mm}$ long and $1.65 \mathrm{~mm}$ wide for 131 segments. Pigmentation absent. Prostomium curved downward anteriorly and distinctly bifid. Four eyes present. Caruncle continuing posteriorly to beginning of setiger 9 . Nuchal tentacle absent (Fig. 22, a, b). Palps extending posteriorly for 15-17 segments.

Setiger 1 with large, flattened notopodial lobes having capillary notosetae. Winged capillary notosetae of anterior setigers $2-4,6$, and succeeding setigers arranged in three successive rows. Caudally, number of setae per notopodial fascicle gradual- 


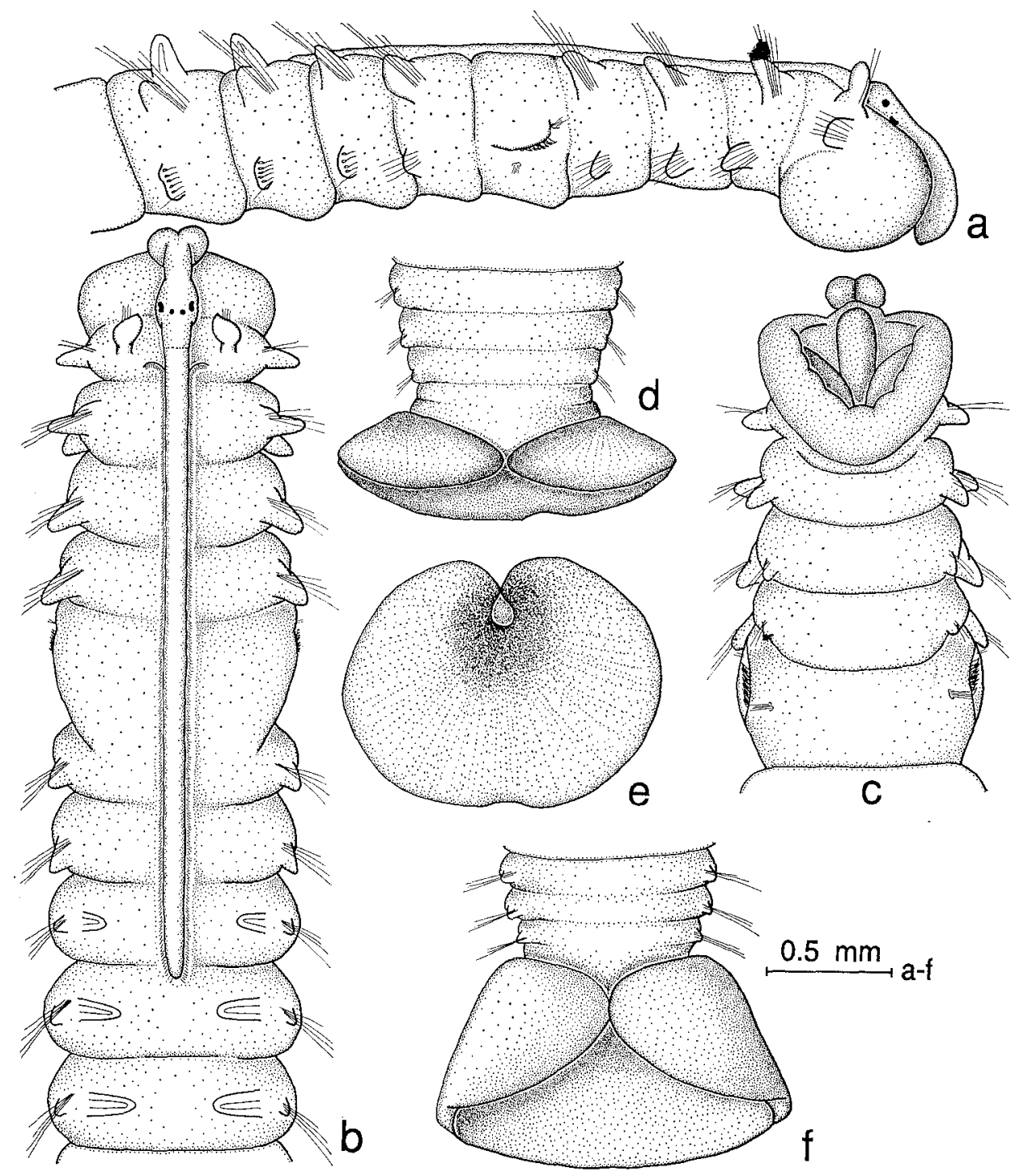

Fig. 22. Polydora carunculata sp. n. a, anterior end, lateral view; b, anterior end, dorsal view; c, anterior end, ventral view; d, posterior end, dorsal view; e, pygidium, posterior view; $f$, posterior end, dorsal view. a-e -holotype, $f$-paratype.

ly diminishing, capillaries of anterior row lacking wings (Fig. 23, a). Specialized posterior notosetae absent. Neurosetae of anterior setigers, except setiger 5 , arranged in two rows. Neuropodial bidentate hooded hooks from setiger 7, without constriction on shaft (Fig. 23, e, g), up to 8 in series. Two or three winged capillary setae (Fig. 23, d) accompanying hooks to setiger 15, then disappearing, and unwinged neurosetae (Fig. 23, f) appearing in posterior setigers.

Setiger 5 twice as large as neighbouring segments, with row of heavy spines alternating with pennoned companion setae (Fig. 23, j). Dorsal tuft of 5 winged setae 


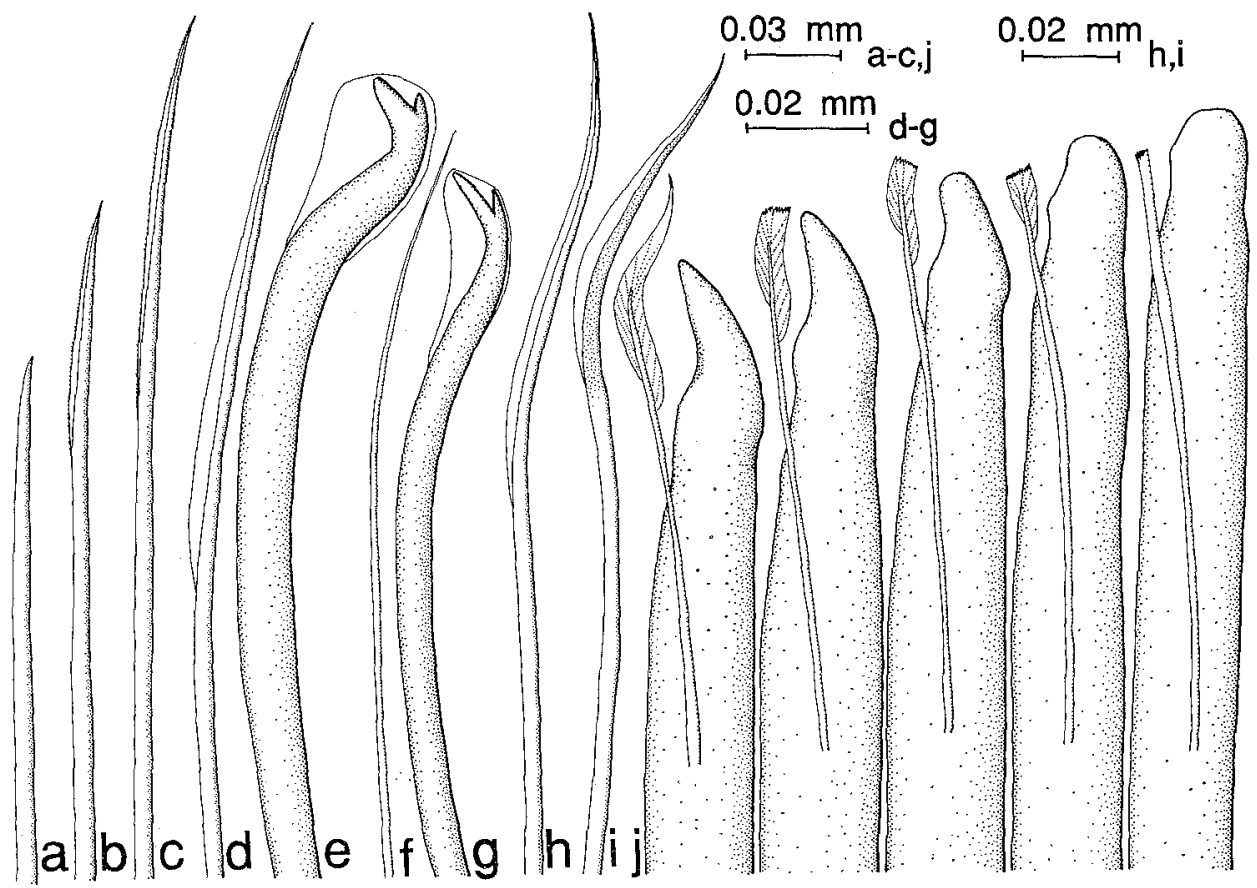

Fig. 23. Polydora carunculata sp.n. a-c, posterior unwinged and winged capillary notosetae; $\mathrm{d}$, e, winged capillary neuroseta and bidentate hooded hook of setiger 7 ; $f, g$, unwinged capillary neuroseta and posterior hooded hook; $h$, dorsal winged seta of setiger 5 ; $\mathrm{i}$, ventral winged seta of setiger 5 ; $\mathrm{j}$, heavy spines and pennoned companion setae of setiger 5 .

(Fig. 23, h) and ventral tuft of 12 winged setae (Fig. 23, i) present. Heavy spines falcate, with small subterminal protuberance, 10 in number.

Branchiae from setiger 8 to setiger 92, small at first, attaining full size on setiger 14.

Pygidium large, thick disc-like with distinct dorsal incision or notch (Fig. 22, $\mathrm{d}, \mathrm{e})$, white colour owing to large number of mucous cells.

Glandular pouches from setiger 6, small at first, attaining full size in setigers 910 and then diminishing in size.

Gizzard-like structure in digestive tract present at level of setigers 21-22. Distal part of rectum white colour in posterior 8-10 setigers.

Oocytes present in setigers 26-94.

Variability. Largest specimens measure $70 \mathrm{~mm}$ in length and have up to 135 segments. Eyes are present or absent, and, if present, there are four. In specimens having up to 60-80 segments, larval pigment is retained on 15-17 anterior segments: there are two rows of small melanophores on the ventral side of the segments, two melanophores on the lower part of the peristomium, orange or rust-coloured pigment inside noto- and neuropodial lobes (Fig. 24, a, b), and black pigment on the dorsal side of segments (Fig. 24, b). The caruncle becomes longer with age: in 60-80segmented specimens it extends back to setiger 5 , but in larger worms the caruncle 

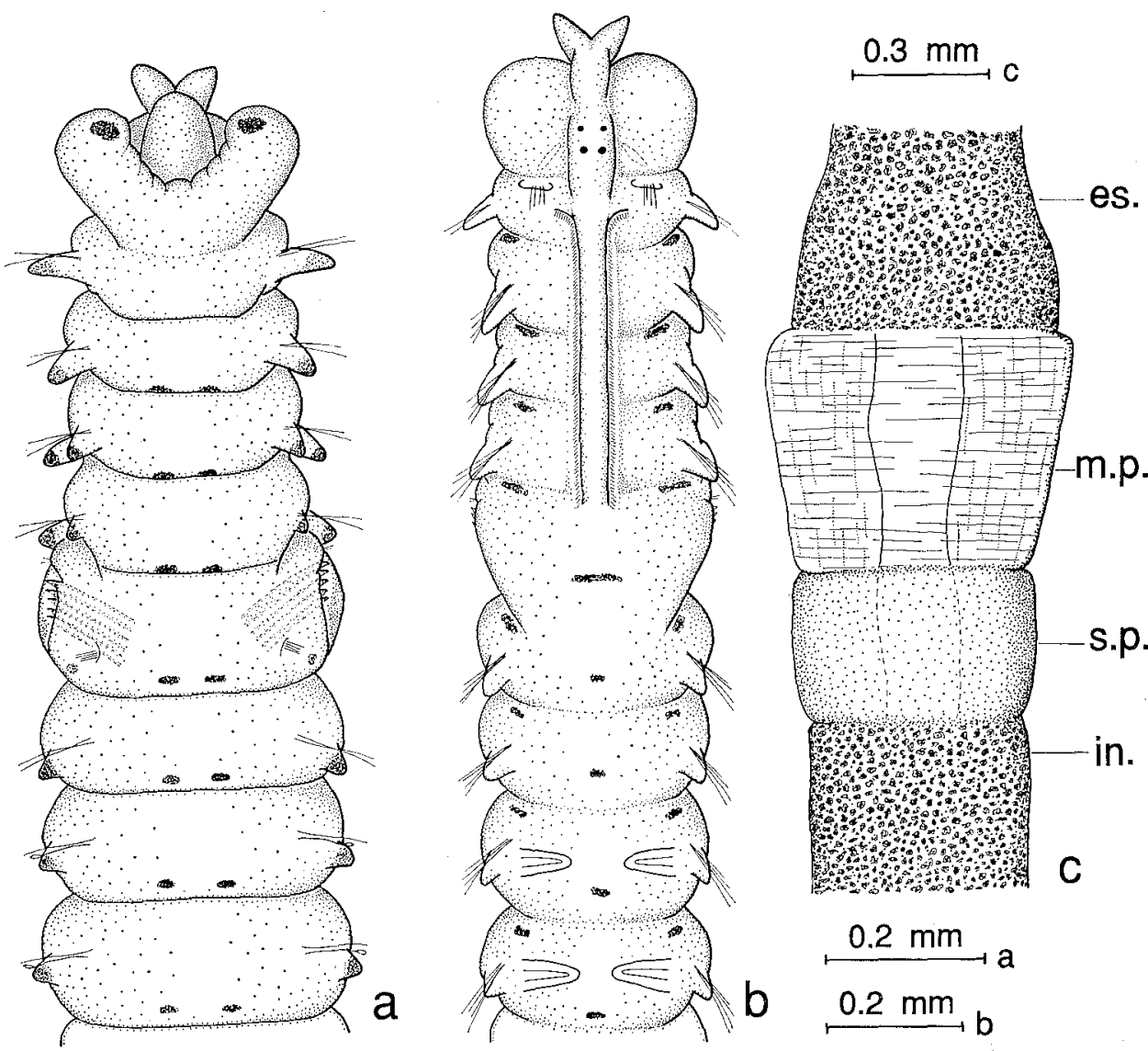

Fig. 24. Polydora carunculata sp. n. a, anterior end of 45-segmented paratype, ventral view; b, anterior end of 70-segmented paratype, dorsal view; c, gizzard-like structure in the digestive tract of 110-segmented paratype, designation the same as in Polydora concharum, see above.

extends to the middle of setiger 8 or to the beginning of setiger 9 . Branchiae usually begin on setiger 8 , but occasionally on setiger 7 or 9 . They are absent from the posterior half or one third of the body. The pygidium is white in colour, usually deep, cup-shaped, and with a dorsal incision (Fig. 22, f). The gizzard-like structure continues for two segments, consists of an anterior transparent muscular part and a posterior white secretory part (Fig. 24, c). It gradually shifts with age, beginning in setigers $12-16$ in small worms and in setigers $20-22$ in larger ones. The rectum is short and white in colour, and continues for 10-20 hinder setigers.

Ecology. Polydora carunculata has been found in Peter the Great Bay at a depth of 3-10 m boring into shells of a scallop $M$. yessoensis, a mussel C. grayanus, an oyster $C$. gigas, living gastropods Acmaea pallida and Nucella heyseana, and empty shells of Cryptonatica janthostoma, Lunatia pila and L. pallida occupied by hermit crabs. It has been also encountered on shells of a mussel Modiolus kurilensis under the crusts of coralline algae. In East Korean, Olga and Vladimir Bays, this species occurs at a depth of 
$5-27 \mathrm{~m}$ in shells of a scallop $M$. yessoensis. Near the Small Kurile Archipelago, one specimen of $P$. carunculata has been found near Polonsky Is. at a depth of $14 \mathrm{~m}$ in shell of Fusitriton oregonense occupied by Pagurus brachiomastus. One specimen of this species has been also found near Moneron Is. at a depth of $15 \mathrm{~m}$ on shell of a mussel C. grayanus. $P$. cartunculata is a rare species and, when found, 1 or 2 individuals occur, as a rule, in one shell.

In Nakhodka Bay, Peter the Great Bay, large aggregation of $P$. carunculata has been found at a depth of $10 \mathrm{~m}$ in a sponge Halichondria panicea (Pallas). In Chikhachev Bay, this species has been found in a sponge Dysidea fragilis (Montagu) and in empty barnacle shells filled with silt. The specimens inhabiting shells and sponges have the same morphological characteristics.

Differenttal diagnosis. Polydora carunculata is related to Polydora socialis (Schmarda, 1861) and Polydora cardalia Berkeley. It is similar to these species in the form of the prostomium, heavy spines of setiger 5 , and arrangement of branchiae. They differ, however, in that $P$. carunculata is a borer and has a pygidium with one dorsal incision, whereas $P$. socialis and $P$. cardalia construct tubes in sediment and have a three-lobed pygidium. Moreover, $P$. cardalia has specialized needle-like capillaries in posterior notopodia, and the caruncle extends to setiger 5 , whereas $P$. carunculata has no specialized posterior notosetae and has a longer caruncle.

Etymology. The epithet is derived from a very long caruncle.

Distribution. Mainland coast of the Sea of Japan: from Chikhachev Bay south to East Korean Bay; Moneron Is.; Small Kurile Archipelago; Oki Islands.

\section{Polydora glycymerica sp. n.}

(Figures $25 \& 26$ )

Type material. The holotype, ZISP 1/46581, Sea of Japan, Vostok Bay, $8 \mathrm{~m}$, sandy bottom, from shell of bivalve Glycymeris yessoensis, 14 November 1983, coll. V. Radashevsky; 10 paratypes, ZISP 5! 46596, Sea of Japan, Vostok Bay, $8 \mathrm{~m}$, sandy bottom, from shells of bivalve Glycymeris yessoensis, 14 November 1983, coll. V. Radashevsky; 50 paratypes, IMBV 1/12172, Sea of Japan, Vostok Bay, $8 \mathrm{~m}$, sandy bottom, from shells of bivalve Glycymeris yessoensis, 5 March 1989, coll. V. Radashevsky. Representative material. Author's collections from Peter the Great Bay and Uspeniya Bay, the Sea of Japan; many specimens.

Description of holotype. Measuring $60 \mathrm{~mm}$ long and $0.9 \mathrm{~mm}$ wide for 250 segments. Body greenish-brown in life. Pair of whitish spots, apparently groups of epidermal mucous cells, present on ventral side of setiger 7 (Fig. 25, c). Prostomium with incision, curved downward anteriorly. Eyes absent. Caruncle continuing posteriorly to middle of setiger 2. Short nuchal tentacle present on caruncle (Fig. 25, a, b). Palps extending posteriorly for 8 segments.

Setiger 1 with only neurosetae, although well developed notopodial lobes present. Winged capillary notosetae of setigers 2-4, 6, and succeeding setigers arranged in three successive rows, setae of hind row longer and thinner. Caudally, number of setae per fascicle gradually diminishing, rows of setae becoming indistinct 


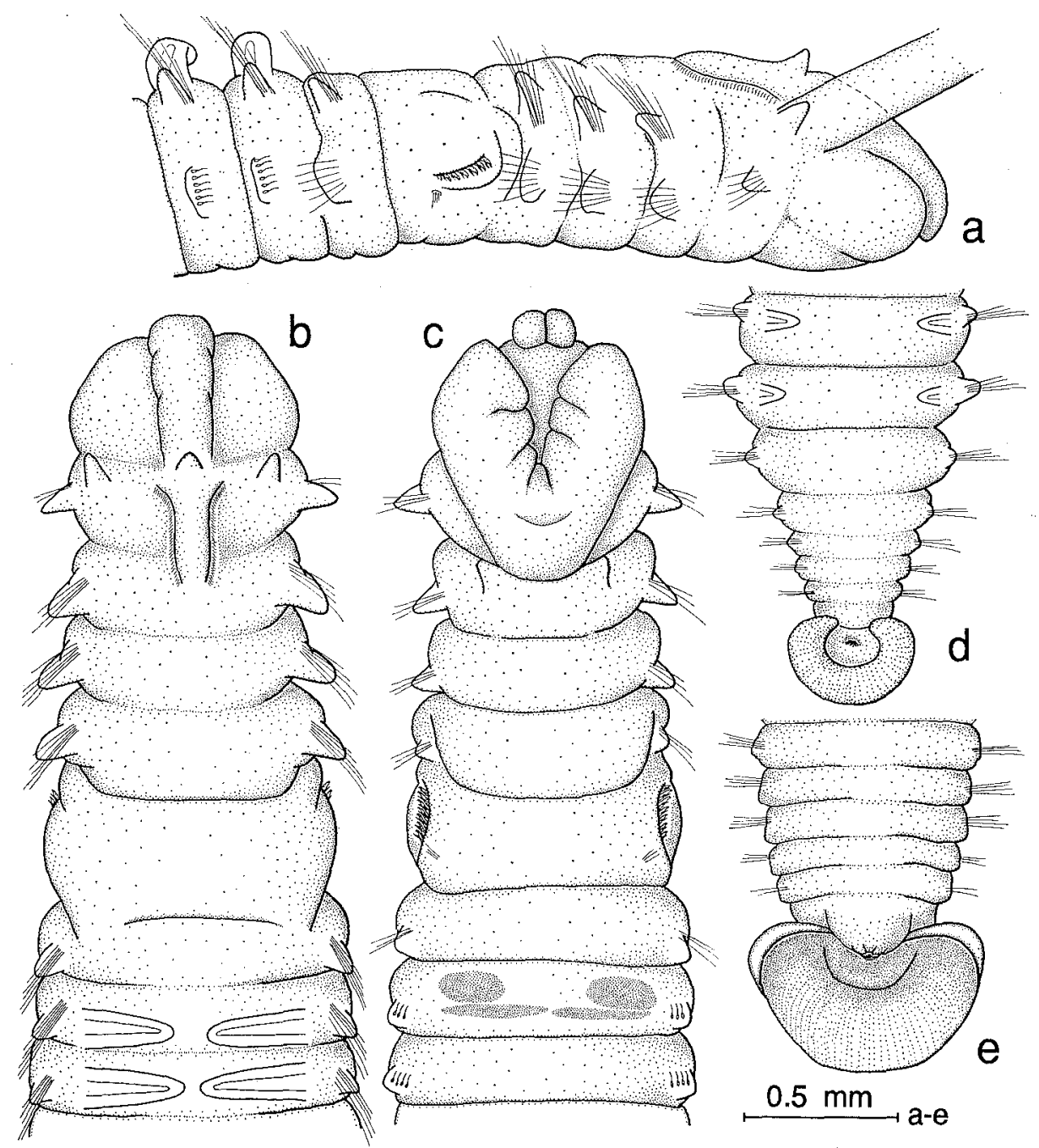

Fig. 25. Polydora glycymerica sp. n. a, anterior end, lateral view; b, anterior end, dorsal view; c, anterior end, ventral view; d,e, posterior end, dorsal view. a-d -holotype, e -paratype.

and capillaries of anterior row missing wings (Fig. 26, a). Specialized setae absent from posterior notopodia. Neuropodial bidentate hooded hooks from setiger 7 , with constriction on shaft, not accompanied by capillary setae (Fig. 26, d, e), up to 10 in series.

Setiger 5 twice as large as neighbouring segments, with row of heavy modified spines alternating with pennoned companion setae (Fig. 26, f). Ventral tuft of 7 winged setae present below and posterior to heavy spines. Dorsal tuft absent. Heavy spines falcate, with lateral flange or sheath (Fig. 26, f, g), 8 in number.

Branchiae from setiger 7, absent from posterior five segments.

Pygidium disc-like with wide dorsal gap, of same colour as body (Fig. 25, d). 


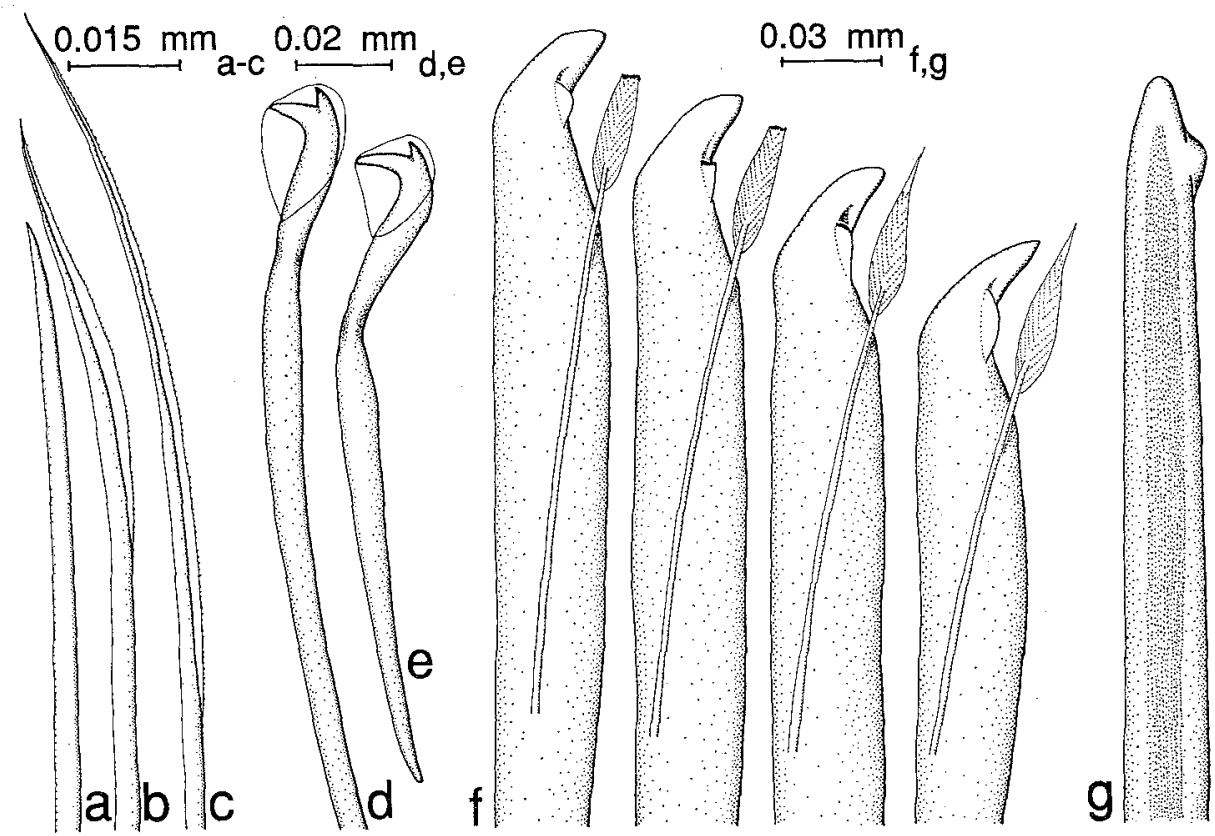

Fig. 26. Polydora glycymerica sp. n. a-c, posterior unwinged and winged capillary notosetae; d, bidentate hooded hook of setiger 7; e, posterior hooded hook; f, heavy spines and pennoned companion setae of setiger $5 ; \mathrm{g}$, heavy spine of setiger 5 , posterior view.

Glandular pouches from setiger 7, large to setigers $10-14$ and then diminishing in size.

Gizzard-like structure in digestive tract absent.

Hermaphroditic specimens with sperm in anterior half of body and oocytes in posterior half.

Variability. Largest specimens measure $88 \mathrm{~mm}$ in length, $1.2 \mathrm{~mm}$ in width on setiger 7 and have up to 300 segments. A prostomial anterior incision may be distinct or weak. The caruncle extends to the anterior border or to the middle of setiger 2 . Small specimens have up to 4 eyes, but in large worms eyes are absent. The pygidium is usually disc-like, but occasionally cup-shaped, with a wide dorsal gap (Fig. 25, e). Ecology. Polydora glycymerica is a specialized commensal borer. It has been found mainly in shells of a bivalve Glycymeris yessoensis (Sowerby). However, two specimens have been encountered in shells of other bivalve, Scapharca broughtoni (Schrenck). $P$. glycymerica is a sole borer of G. yessoensis shells. A maximum of 6 polychaetes can be found in a valve, and 8 in one mollusc. The burrows of the worms are U-shaped, long and wide. The inner walls of the burrows are lined with silt. Both openings of the burrow are located on the posterior end of the shell in the region of the mollusc's siphons. Such a position of the openings is closely associated with the mode of feeding. Projecting out of the burrow, the worms expose their palps and catch suspended particles from the water current produced by the mollusc. 
Differential diagnosis. Polydora glycymerica resembles Polydora hornelli Willey, 1905 from India, Polydora sp. found by Masagaki (1936) in Anadara inflata (Reeve) from Japan, Polydora pacifica described by Takahashi (1937) from shells of a pearl oyster Pinctada margaritifera (Linné) from the Palao Islands, Polydora websteri described by Hartman (1943) from North America, and widely distributed Polydora ciliata (Johnston, 1838). It differs from the above-mentioned species in having a nuchal tentacle and in a shorter caruncle. Moreover, P. glycymerica is distinguished from Polydora sp. Masagaki (1936) by the number of branchiae, from $P$. pacifica by having shorter palps and smaller number of spines on setiger 5 , and from $P$. websteri and $P$. ciliata by greater size.

P. glycymerica is closely related to Polydora vulgaris described by Mohammad (1972) from shells of a pearl oyster Pinctada margaritifera from Arabian Gulf. It differs from the latter species by the absence of needle-like spines in posterior notopodia. Etymology. The epithet is derived from the name of the host bivalve Glycymeris yessoensis.

Distribution. Mainland coast of North Japan Sea: Peter the Great Bay and Uspeniya Bay.

\section{Genus Pseudopolydora Czerniavsky, 1881}

Type species: Pseudopolydora antennata (Claparède, 1870).

Diagnosis: Prostomium narrow, anteriorly rounded to bifid. Setiger 1 with or without notosetae. Setiger 5 generally not distinctly enlarged, with noto- and neuropodia often well-developed; major spines of two types in J- or U- shaped double row. Bidentate hooded hooks from setiger 8 , S-shaped, with constriction on shaft. Branchiae posterior to setiger 5 .

Key to the species of Pseudopolydora from the North West Pacific (* denotes species found by the author in the North West Pacific but not included in the present paper)

1. Prostomium bifid. Pygidium with two lateral processes........* $P$. kempi japonica

- Prostomium rounded. Pygidium without lateral processes.....P. paucibranchiata

\section{Pseudopolydora paucibranchiata (Okuda, 1937)}

(Figure 27)

Polydora (Carazzia) paucibranchiata Okuda, 1937, pp. 231-233, figs 11-12. --Uschakov \& Wu, 1963, pp. 154-164.

PPolydora (Carazzia) derjugini Zachs, 1933, p. 130.

Polydora (Carazzia) orientalis Annenkova, 1937, pp. 170-171, table 5, fig. 54 d-i; 1938, p. 178. --Uschakov, 1955 (Part.), pp. 269-270, fig. 94 N-O, syn., excl. Uschakov, 1950, p. 201; 1953, p. 145; 1959, p. 205.

Pseudopolydora paucibranchiata: Imajima \& Hartman, 1964, p. 288. --Blake \& Woodwick, 1975, pp. 110-118, figs 1-11. --Read, 1975, pp. 414-416, fig. 7. --Light, 1977, pp. 71-72, syn.; 1978, pp. 161-163, figs 162-163. --Blake \& Kudenov, 1978, p. 268. --Myohara, 1980, pp. 145-155, 2 text-figs, 1 table, 3 pls. -Wu \& Mu, 1980, pp. 356-364, figs 1-6. --? Ramberg \& Schram, 
1982, pp. 244-246, fig. 8. --Radashevsky, 1983, pp. 38-46, figs 1-2. --Hutchings \& Turvey, 1984, p. 17, fig. 7. --Britayev \& Rzhavsky, 1985, pp. 47-49, figs 1-2. --Buzhinskaja, 1985, p. 132. Pseudopolydora kempi: Hutchings \& Rainer, 1979, pp. 773-774. Not Southern, 1921, p. 636.

Not Polydora (Carazzia) orientalis: Uschakov, 1950, p. 201; 1953, p. 145.

Material examined. Syntypes of Polydora orientalis Annenkova: ZISP 2/25705, anterior ends of two worms and posterior end without pygidium mounted on a slide; ZISP 2/25705a, posterior end without pygidium; ZISP 2/25705b, specialized setae of setiger 5 mounted on a slide; ZISP 2/25705c, capillary notosetae and hooded hooks neurosetae from middle part of the body mounted on a slide; Sea of Japan, Peter the Great Bay, Strelok Bay, 2 m, dredged, 4 September 1929, coll. Vedensky. Pseudopolydora paucibranchiata: USNM 135425, Sea of Japan, Vostok Bay, $4 \mathrm{~m}$, muddy sand, 9 spec., 16 October 1990, coll. V. Radashevsky; NSMT-Pol. 97639-97643, Sakhalin Is., Busse Lagoon of Aniva Bay, intertidal, muddy sand, 5 spec., 4 July 1990, coll. V. Radashevsky.

Author's collections from East Korean Bay; Peter the Great Bay; Olga Bay; Vladimir Bay; Chikhachev Bay; Moneron Is.; Sakhalin Is.: Aniva Bay: Busse Lagoon; Kunashir Is.: Izmeny Bay; many specimens.

Description. Specimens up to $18 \mathrm{~mm}$ long and $0.54 \mathrm{~mm}$ wide for 65 segments. Small polychaetes, up to 40 -segmented stage, sometimes with larval melanophores on dorsal side of anterior segments (Fig. 27, a, b). Larger worms without body pigmentation. Branching yellow chromatophores present along palps in living polychaetes (Fig. 27, b), but absent in fixed worms.

Prostomium rounded anteriorly. Four eyes present. Caruncle continuing posteriorly to setiger 4 . Nuchal tentacle present on caruncle at level of palps (Fig. 27, a, b). Palps long, extending posteriorly for 25-28 segments.

Setiger 1 with only neurosetac. Notosetae absent, although well developed notopodial lobes present. About 10 cross rows of short, probably sensory, cirri present between notopodial and neuropodial lobes of setiger 1. Neuropodial bidentate hooded hooks from setiger 8 , S-shaped, with constriction on shaft and not accompanied by capillary setae (Fig. 27, c), up to 14 in series.

Setiger 5 not modified. Parapodia with two rows of spines arranged in Ushaped series. Dorsal tuft of up to 10 and ventral tuft of up to 15 winged capillary setae present. Spines constituting outer row with curved tip and constriction between tip and shaft (Fig. 27, d), spines of inner row falcate (Fig. 27, e). Up to 13 spines present in each row.

Branchiae from setiger 7 , absent from posterior half of body, numbering up to 20 pairs.

Pygidium cup-shaped or consisting of ventral, collar-like disc, with large dorsal gap, greatly variable in size (Fig. 27, $\mathrm{f}, \mathrm{g}$ ).

Glandular pouches from setiger 1, small at first, attaining full size in setigers 6-7, then diminishing in size after setigers 15-16, absent after setigers 17-20.

Gizzard-like structure in digestive tract absent.

Ecology. Pseudopolydora paucibranchiata commonly forms dense populations on muddy bottom in estuarise. The population density may amount to several thousand individuals per 1 square metre. The tubes of the worms have up to $4 \mathrm{~cm}$ in length, about $1 \mathrm{~mm}$ in width and project $0.5-1 \mathrm{~cm}$ above the surface of the bottom. The upper part of the tubes is greyish and smooth on outer surface. The lower part is rough 


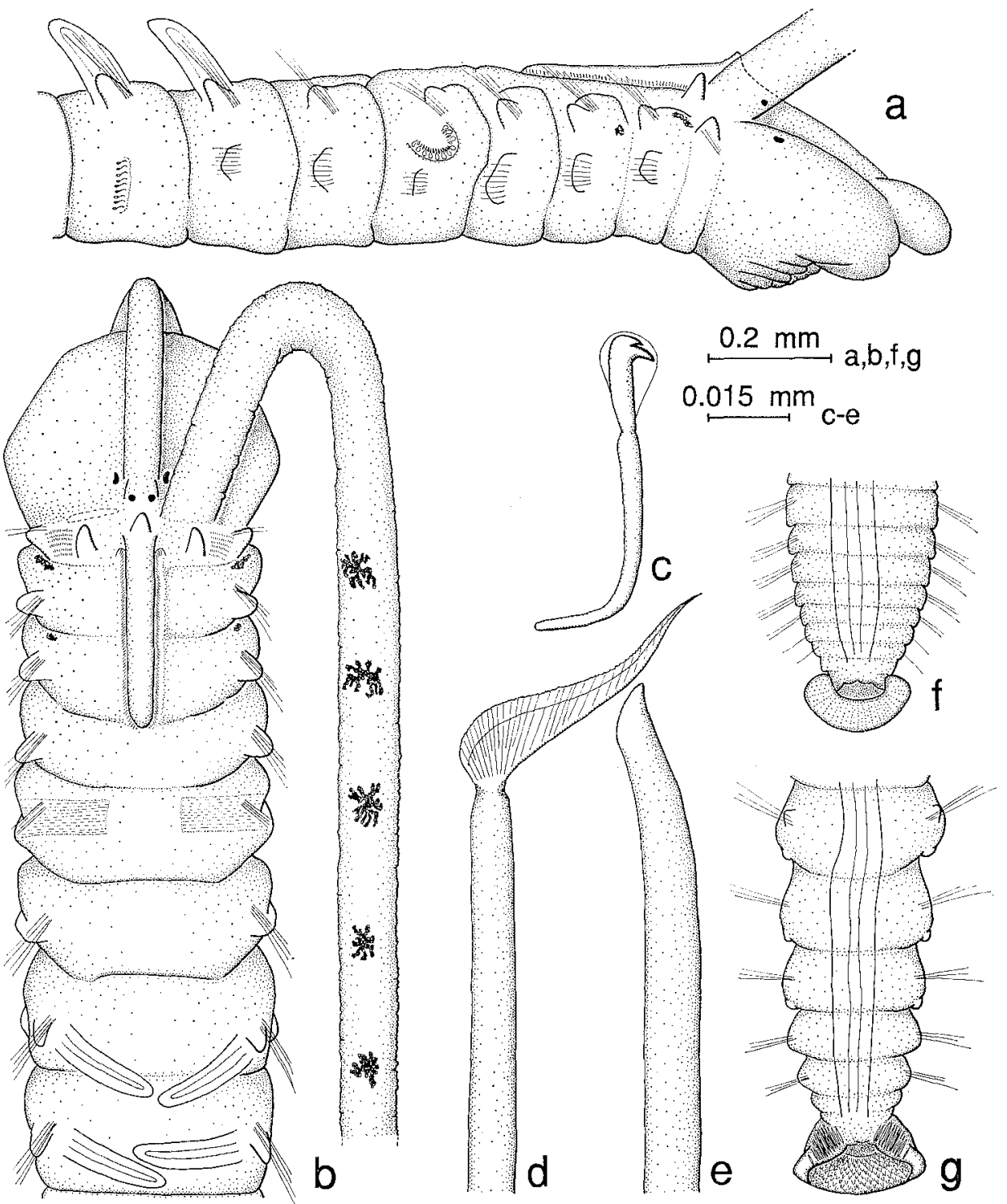

Fig. 27. Pseudopolydora paucibranchiata (Okuda). a, anterior end, lateral view; b, anterior end, dorsal view; c, bidentate hooded hook of setiger 8 ; d, outer heavy spine of setiger 5 ; e, inner heavy spine of setiger $5 ; \mathrm{f}, \mathrm{g}$, posterior end, dorsal view.

and rust-coloured.

$P$. paucibranchiata is a warm-water species. In the North Japan Sea, Sakhalin and Kunashir Is., it occurs in shallow, warm-water bays or lagoons.

Remarks. P. paucibranchiata was first described from Japan, Onomichi, Inland Sea, by Okuda (1937). He gave a detailed description of a new species and reported a small dorsal lobe with a few very fine bristles situated on the first setiger. This 
character creates difficulties in identification of this species. Imajima \& Hartman (1964) presumed that a small lobe of first setiger with fine setae is neuropodial. Unfortunately, this presumption may not be exactly defined since the type material of $P$. paucibranchiata was destroyed during the Second World War (Hutchings \& Turvey, 1984). According to the data presented in this paper and to information of other authors (Blake \& Kudenov, 1978), P. paucibranchiata has no capillary notosetae on setiger 1 . This feature appears to be a characteristic of this species.

Polydora orientalis described by Annenkova (1937) from Peter the Great Bay is referred to $P$. paucibranchiata. The Annenkova's description of $P$. orientalis differs from $P$. paucibranchiata only in that hooded hooks begin on setiger 7 and not on setiger 8 . The type material of $P$. orientalis has been examined and hooks found beginning on setiger 8 . The Annenkova's paper was published several months after the work of Okuda had appeared, hence $P$. orientalis is a junior synonym.

The worms reported by Uschakov $(1950,1953)$ from the Okhotsk Sea as Polydora orientalis ( $P$. orientalis: ZISP 1) have been examined and referred to Polydora caulleryi Mensil, 1897.

Polydora (Carazzia) derjugini Zachs (1933) from Peter the Great Bay appears to be placed in synonymy with $P$. paucibranchiata, but this is questionable, since the type material of $P$. derjugini is lost and the description, given by Zachs, is not adequate for specific determination.

Ramberg \& Schram (1982) recorded P. paucibranchiata from Oslofjord, Norway. This is the first record of the species outside the Pacific. The characters of Norwegian polychaetes mainly correspond to those from the Sea of Japan, but some differences exist. The polychaetes from Oslofjord have no nuchal tentacle, and each egg capsule deposited by females is fastened separately by two threads to the inner wall of the tube, whereas the specimens from the Sea of Japan have nuchal tentacle, and each egg capsule is joined to the next one and attached to the tube by one thin extension (Radashevsky, 1983). Whether these differences are interspecific or intraspecific is under consideration.

New record. First record for the Kurile Islands.

Distribution. Mainland coast of the Sea of Japan: from Chikhachev Bay south to East Korean Bay; Yellow Sea: Tsingtao (Qingdao), Yantai; Moneron Is.; Sakhalin Is.: Busse Lagoon; Kunashir Is.: Izmeny Bay; Inland Sea, Japan; California; South East Australia: New South Wales, Victoria, South Australia; New Zealand: Wellington Harbour; ? Norway: Oslof jord.

\section{Summary}

Fourteen species of four genera, Boccardiella, Neoboccardia, Polydora and Pseudopolydora, of polychaete family Spionidae from the North West Pacific are described on the basis of author's collections as well as material deposited in five museums. Of these, eight are previously described species: Boccardiella hamata (Webster, 1879), Neoboccardia perata (Chlebovitsch, 1959), Polydora commensalis Andrews, 1891, Poly- 
dora concharum Verrill, 1880, Polydora quadrilobata Jacobi, 1883, Polydora spongicola Berkeley et Berkeley, 1950, Polydora cardalia E. Berkeley, 1927, and Pseudopolydora faucibranchiata (Okuda, 1937). Two subspecies, Polydora ciliata brevipalpa Zachs, 1933 and Polydora flava bidentata Zachs, 1933, are raised in rank and are redescribed as Polydora brevipalpa and Polydora bidentata, respectively. Four species, Polydora trilobata, Polydora alborectalis, Polydora carunculata and Polydora glycymerica, are described as new to science. Descriptions, figures and ecological data of the species covered, keys to the species of Polydora and Pseudopolydora from the North West Pacific, and diagnoses of the genera covered are included.

New synonymies include Polydora uschakovi Buzhinskaja, 1971, referred to $P$. spondicola, Polydora socialis plena Berkeley et Berkeley, 1936 and Polydora soederstroemi Annenkova, 1938, both referred to P. cardalia, Polydora variegata Imajima et Sato, 1984, referred to $P$. brevipalpa, and Polydora ciliata possjetica Buzhinskaja, 1971 and Polydora convexa Blake et Woodwick, 1972, both referred to P. bidentata.

Two species, $P$. spongicola and $P$. cardalia, are reported for the first time for the North West Pacific, and one species, $P$. bidentata, for the North East Pacific. P. cardalia is reported for the first time for the Chukotsk Sea, $B$. hamata, $N$. perata and $P$. concharum are reoprted for the first time for the Sea of Japan, $P$. commensalis, $P$. brevipalpa, $P$. bidentata and $P$. paucibranchiata for the Kurile Islands, $P$. quadrilobata for the Aleutian Islands, $P$. commensalis for Sakhalin, and $P$. brevipalpa for Japan.

One species, P. glycymerica, to date is an endemic of the Sea of Japan. N. perata, $P$. brevipalpa and $P$. carunculata are Pacific Asiatic low-boreal species. P. trilobata and $P$. alborectalis are Pacific Asiatic widely distributed boreal species. P. spongicola and $P$. bidentata are amphipacific species distributed on low-boreal waters of both Asiatic and American coasts. P. cardalia is apparently widely distributed amphipacific boreal species or even boreo-arctic species. B. hamata, $P$. commensalis and $P$. concharum are amphiboreal species widely distributed in the Altantic and Pacific boreal waters. $P$. quadrilobata is a boreo-arctic species. P. paucibranchiata is a bipolar species.

Examination of old materials reveals that four previously reported species, Polydora caeca (Oersted, 1843), Polydora flava Claparède, 1870, Polydora colonia Moore, 1907, and Boccardia natrix (Söderström, 1920), are absent in the North West Pacific. The record of Polydora (Boccardia) polybranchia Haswell, 1885 from the Bering Strait by Annenkova (1952) is questionable. Unfortunately, the Annennkova's material is lost and her reference may not be defined exactly.

Nine species were found boring into shells or other calcareous structures. Three of these, $P$. commensalis, $P$. brevipalpa and $P$. glycymerica, are commensal species connected with definite host. The other six species, $B$. hamata, $P$. concharum, $P$. bidentata, $P$. trilobata, $P$. alborectalis and $P$. carunculata, bore into various calcareous substrata. Occasionally, B. hamata inhabits mud tubes on oyster surface, and P. carunculata bores into sponges. $P$. spongicola bores into sponges only. Four species, $N$. perata, $P$. quadrilobata, $P$. cardalia and $P$. paucibranchiata, are found in sediment.

A unique pygidium transformation with age from four-lobed to three-lobed form is described in $P$. cardalia. 


\section{Acknowledgements}

I wish to offer my cordial gratitude to Galina N. Buzhinskaja and Vjacheslav V. Potin, Zoological Institute, St. Petersburg for thier assistance during my visits to ZISP. They provided working space, offered advice and allowed me to examine the Institute collection of polychaetes. I am grateful to Linda A. Ward, Smithsonian Institution, Nora R. Foster, University of Alaska, Museum, Takumu Kato, High-School teacher, Japan, and Alexander V. Rzhavsky, Pacific Institute of Geography, for loaning or providing the material. I am also grateful to the following persons for identification of species: Maria B. Ivanova, IMBV (Bivalvia); Vladimir V. Gulbin, IMBV (Gastropoda); Ida I. Ovsyannikova, IMBV (Cirripedia); and Alexander V. Ereskovsky, ZISP (Spongia). Sincere thanks are due to the chiefs of expeditions Victor E. Gemelyuk, Vitaly G. Tarasov, Sergei M. Dolganov and Valery I. Fadeev for inviting me to take part in IMBV Expeditions. I express my deepest gratitude to Diving Service of the IMBV for helping in the field. My thanks are due to Tatjana N. Koznova for help in preparing an English version of manuscript, to Igor A. Jirkov and Oleg G. Kussakin for critically reading of the manuscript. Assistance rendered by Vladimir L. Kasyanov, Vera N. Radashevskaja and Anatoly V. Schkoldin is also gratefully acknowledged. I wish to express my hearty thanks to anonymous reviewers for careful reading of the manuscript.

\section{References}

Andrews, E.A. 1891a. A commensal annelid. Am. Nat., 25: 25-35, 2 pls.

- 1891b. Report on the Annelida Polychacta of Beaufort, North Carolina. Proc. U.S. natn. Mus., 14: 277-302, pls. 12-18.

Annenkova, N. 1931. Die Polychaeten in den Sammlungen der jakutischen Expedition der Akademie der Wissenschaften der USSR. Zool. Anz., 95: 203-205, 4 figs.

_-_. 1932a. Zur Fauna der "Polychaeta" von Franz-Joseph Land. Trudy Arkticheskogo Ins., 2: 153-194, 7 figs. (In Russian with German summary).

- 1932b. The polychaete fauna of the Laptev Sea. Explor. Seas USSR, 15: 133-139, 7 figs. (In Russian with German summary).

- 1934. Kurze Übersicht der Polychaeten der Litoralzone der Bering-Insel (KommandorInseln), Nebst Beschreibung neuer Arten. Zool. Anz., 106(12): 322-331, 11 figs.

—_ 1937. Fauna of the Polychaeta of the North Japan Sea. Explor. Seas USSR, 23: 139216. (In Russian with English summary).

_- 1938. Polychaeta of the North Japan Sea and their horizontal and vertical distribution. Reports of the Japan Sea hydrobiological expedition of the Zoological Institute of the Academy of Sciences of the USSR in 1934, 1: 81-230, 16 figs. (In Russian with English summary).

- 1952. Polychaeta from the Chukotsk Sea and Bering Strait. In: Kraynii severo-vostok Sojuza SSR, vol. 2. Fauna i flora Chukotskogo morya, Izd. Acad. Nauk SSSR, Moscow-Leningrad. 112-137, 7 figs. (In Russian).

Bagaveeva, E.V. 1981. Polychaetous worms Hydroides elegans and Polydora limicola in fouling communities of the Sea of Japan. In: O.G. Reznichenko \& I.V. Starostin (eds.), Foulings and biocorrosion in aquatic environments, Nauka Press, Moscow. 13-17. (In Russian).

1986. Biogeographical and biotopic study of fouling polychaetes of the north-western Sea of Japan. Mar. Biol., Vladivostok, 1 : 9-15, 3 figs., 1 tbl. (In Russian with English summary).

1988. Polychactes in the fouling of coastal ships in the north-western Sea of Japan. Mar. Biol., Vladivostok, 3: 22-26, 3 figs., 1 tbl. (In Russian with English summary).

Berkeley, E. 1927. Polychaetous annelids from the Nanaimo district. 3. Leodicidae to Spionidae. Contr. Can. Biol., N.S., 3: 407-422, 1 pl.

_ \& G. Berkeley. 1936. Note on Polychaeta from the coast of western Canada. I. Spionidae. Ann. Mag. nat. Hist., Ser. 10, 18: 468-477, 1 fig.

\& 1943 . Biological and oceanographic conditions in Hudson Bay. II. Polychaeta from Hudson Bay. J. Fish. Res. Bd. Canada, 6: 129-132.

- \& 1950. Notes on Polychaeta from the coast of western Canada. IV. Polychaeta 
Sedentaria. Ann. Mag. nat. Hist., ser. 12, 3(25): 50-69, 8 figs.

\& 1952. Annelida. Polychaeta Sedentaria. In: Canadian Pacific Fauna. Fish. Res. Bd. Canada, 9b(2): 1-139, 292 figs.

\& 1954. Additions to the polychaete fauna of Canada with comments on some older records. J. Fish. Res. Bd. Canada, 11(4): 454-471, 16 figs.

__ \& 1956. On a collection of polychaetous annelids from northern Banks Island, from the south Beaufort Sea, and from northwest Alaska; together with some new records from the east coast of Canada. J. Fish. Res. Bd. Canada, 13(2): 233-246.

Bick, A. \& F. Gosselck. 1985. Arbeitsschlüssel zur Bestimmung der Polychaeten der Ostsee. Mitt. zool. Mus. Berl., 61(2): 171-272, 393 figs., 45 pls.

Blake, J.A. 1966. On Boccardia hamata (Webster), new combination (Polychaeta, Spionidae), Bull. South. Galif. Acad. Sci, 65(3): 176-184. 2 pls.

- 1969a. Systematics and ecology of shell-boring polychaetes from New England. Am. Zool., 9: 813-820, 9 figs.

- 1969b. Reproduction and larval development of Polydora from northern New England (Polychaeta: Spionidae). Ophelia, 7:1-63, 40 figs.

1971. Revision of the genus Polydora from the east coast of North America (Polychaeta: Spionidae). Smithson. Contr. Zool., 75: 1-32, 16 figs., 1 tbl.

-1979. Revision of some polydorids (Polychaeta: Spionidae) described and redescribed from British Columbia by Edith and Cyril Berkeley. Proc. biol. Soc. Wash., 92(3): 606-617, 3 figs.

- 1980. Polydora and Bociardia species (Polychaeta: Spionidae) from western Mexico, chiefly from calcareous habitats. Proc. biol. Soc. Wash., 93(4): 947-962, 5 figs.

\& D. Dean. 1973. Polychaetous annelids collected by the R/V Hero from Baffin Island, Davis Strait, and West Greenland in 1968. Bull. South. Calif. Acad. Sci., 72(1): 31-39.

- \& J.W. Evans. 1973. Polydora and related genera as borers in mollusk shell and other calcareous substrates (Polychacta: Spionidae). Veliger, 15(3): 235-249, 4 figs., 5 tbls.

— \& J.D. Kudenov. 1978. The Spionidae (Polychaeta) from southeastern Australia and adjacent areas with a revision of the genera. Mem. nat. Mus. Vict., 39: 171-280, 50 figs.

\& K.H. Woodwick. 1972. New species of Polydora (Polychaeta: Spionidae) from the coast of California. Bull. South. Calif. Acad. Sci., 70(2): 72--79, 5 figs.

- \& 1975. Reproduction and larval development of Pseudopolydora paucibranchiata (Okuda) and Pseudopolydora kempi (Southern) (Polychaeta: Spionidae). Biol. Bull., 149: 109-127, 22 figs., 2 tbls.

Britayev, T.A. \& A.V. Rzhavsky. 1985. Contribution to the fauna of polydorids (Polychaeta, Spionidae) of the Sea of Japan. Bull. mosk. Obshch. Ispytat. Prirody. Otd. Biol., 90(1): 45-50, 2 figs. (In Russian).

Buzhinskaja, G.N. 1967. On the ecology of the polychaetous annelids of the Possjet Bay (the Sea of Japan). Explor. Fauna Seas, 5(13): 78-124, 6 figs. (In Russian).

- 1971. New and interesting species of Polychaeta worms of the Possjet Bay of the Sea of Japan. Explor. Fauna Seas, 8(16): 123-136, 3 figs., 1 tbl. (In Russian).

1985. Polychaeta of the shelf of south Sakhalin and their ecology. Explor. Fauna Seas, 30(38): 72-224, 31 figs., 4 tbls. (In Russian with English summary).

Chlebovitsch, V.V. 1959. Species of Polychaeta worms from the Kurile Islands, which are new or recorded for the first time in the USSR fauna. Zool. Zh., 38(2): 167-181, I0 figs. (In Russian with English summary).

- 1961. The polychaetous annelids of the tidal zone of the Kurile Islands. Explor. Far East. Seas USSR, 7: 151-260, 14 figs., 8 tbls., 7 maps. (In Russian).

Claparède, E. 1870. Les Annélides Chétopodes du Golfe de Naples. Mém. Soc. Phis. Hist. nat. Genève, $20(2): 365-542,14$ pls.

Evans, J.W. 1969. Borers in the shell of the sea scallop, Placopecten magellanicus. Am. Zool,, 9: 775782,13 figs.

Dauer, D. 1991. Functional morphology and feeding behaviour of Polydora commensalis (Polychaeta: Spionidae). Ophelia, Suppl., 5: 607-614. 
Fauvel, P. 1927. Polychètes sedentaires. Addenda aux Errantes, Archiannélides, Myzostomaires. Faune Fr., 16: 1-494, 152 figs.

Foster, N.M. 1971. Spionidae (Polychaeta) of the Gulf of Mexico and the Caribbean Sea. Stud. Fauna Curaçao, 36(129): 1-183, 285 figs.

Gerasimov, S.L. 1983. Peculiarities of infestation of the mussel Crenomytilus grayanus by various borers. In: V.A. Sveshnikov (ed.), Biology of the mussel Crenomytilus grayanus, Nauka Press, Moscow. 123129, 2 figs., 1 tbl. (In Russian).

Hannerz, L. 1956. Larval development of the polychaete families Spionidae Sars, Disomidae Mesnil and Poecilochaetidae n. fam. in the Gullmar Fjord (Sweden). Zool. Bidr. Uppsala, 31: 1-204, 57 figs.

Hartman, O. 1941. Some contributions to the biology and life history of Spionidae from California. Allan Hancock Pac. Exped., 7(4): 289-323, pls. 45-48.

- 1943. Description of Polydora websteri, n. sp. In: V.L. Loosanoff \& J.P. Engle, Polydora in oysters suspended in the water. Biol. Bull., 85: 69-78, fig. 1.

- 1944a. New England Annelida, Part 2. Bull. Am. Mus. Nat. Hist., 82(7): 331-343, pls. 45-60.

- 1944b. Polychaetous annelids from California, including the description of two new genera and nine new species. Allan Hancock Pac. Exped., 10(2): 239 315, pls. 19-26.

- 1945. The marine annelids of North Garolina. Bull. Duke Univ. mar. Stn., 2: 1-54, 10 pls.

- 1951. The littoral marine annelids of the Gulf of Mexico. Publ. Inst. mar. Sci. Univ. Taxas, 2: 7-124, 27 pls.

- 1954. The marine annelids of San Francisco Bay and its environs, California. Allan Hancock Found. Publ. Occ. Pap., 15: 1-20.

1959. Catalogue of the polychaetous annelids of the world. Parts I and II. Allan Hancock Found. Publ. Occ. Pap., 23: 1-628.

__. 1961. Polychaetous annelids from California. Allan Hancock Pac. Exped., 25: 1-226, 34 pls.

——. 1969. Atlas of the sedentariate polychaetous annelids from California. Allan Hancock Foundation, Los Angeles, Calif., 812 pp., with figures.

Hartmann-Schröder, G. 1971. Annelida, Borstenwürmer, Polychaeta. Die Tierwelt Deutschlands, 58: 1-594, 190 figs.

Hatfield, P.A. 1965. Polydora commensalis Andrews - larval development and observations on adults. Biol. Bull., 128(3): 356-368, 5 figs.

Hempel, C. 1957. Zur Ökologie einiger Spioniden (Polychaeta, Sedentaria) der deutschen Küsten. Kieler Meeresforsch., 13: 275-288.

Hoberg, M.K.g S.G. McGee \& H.M. Feder. 1982. Polychaetes and amphipods as commensals with pagurids from the Alaska shelf. Ophelia, 21(2): 167-179, 1 fig., 3 tbls.

Hobson, K.D. \& K. Banse. 1981. Sedentariate and archiannelid polychaetes of British Columbia and Washington. Can. Bull. Fish. Aquat. Sci., 209: 1-144, 29 figs., 6 tbls.

Hutchings, P. \& S. Rainer. 1979. The polychaete fauna of Careel Bay, Pittwater, New South Wales, Australia. J. Nat. Hist., 13(6): 745-796, 10 figs.

— \& S.P. Turvey. 1984. The Spionidae of South Australia (Annelida: Polychaeta). Trans. R. Soc. South Australia, 108(1): 1-20, 9 figs., 1 tbl.

Imajima, M. \& O. Hartman. 1964. The polychaetous annelids of Japan. Part II. Allan Hancock Found. Publ. Occ. Pap., 26: 239-452, pls. 36-38.

\& W. Sato. 1984. A new species of Polydora (Polychaeta, Spionidae) collected from Abashiri Bay, Hokkaido. Bull. nath. Sci. Mus., Tokyo, Ser. A, 10(2): 57-62, 26 figs., 1 tbl.

Jacobi, R. 1883. Anatomisch-histologische Untersuchung der Polydoren der Kieler Bucht. Inaug. Dissertation, 35 pp., 2 pls. Kiel.

Johnston, G. 1838. Miscellanea Zoologica. Aricidae. Mag. Zool. Bot. Edinburg, 2: 62-73, pls. $2-3$.

Kussakin, O.G. 1975. A list of the macrofauna in the intertidal zone of the Kurile Islands, with remarks on zoogeographical structure of the region. Publ. Seto Mar. Biol. Lab., 22(3/6): 47-74, 3 figs., 1 tbl. 
1978. Bionomy and phenology of the intertidal zone in the Krabovaya Bay (Shikotan, the Kurile Islands). In: O.G. Kussakin (ed.), Fauna and vegetation of the shelf of the Kurile Islands, Nauka Press, Moscow. 5-46, 25 tbls. (In Russian with English summary).

Light, W.J. 1977. Spionidae (Annelida: Polychaeta) from San Francisco Bay, California: a revised list of nomenclatural changes, new records, and comments on related species from the northeastern Pacific Ocean. Proc. biol. Soc. Wash., 90(1): 66-88, 5 figs.

- 1978. Spionidae Polychaeta Annelida. Invertebrates of the San Francisco Bay Estuary System. Boxwood Press, Pacific Grove Calif., i-xii, 1-211, 186 figs., 3 maps.

Masagaki, Y. 1936. Polychaeta, which makes blister in Anadara inflata. Kagaku, 6(7): 275-276. (In Japanese).

Mesnil, F. 1897. Études de morphologie externe chez les annélides. II. Remarques complémentaires sur les Spionidiens. La famille nouvelle des Disomidiens. La place des Aonides (sensu Tauber, Levinsen). Bull. sci. Fr. Belg., 30: 83-100, pl. III.

Mohammad, M.-B.M. 1972. Infestation of the pearl oyster Pinctada margaritifera (Linné) by a new species of Polydora in Kuwait, Arabian Gulf. Hydrobiologia, 39(4): 463-477, 9 figs, 2 tbls.

Moore, J.P. 1907. Descriptions of new species of spioniform annelids. Proc. Acad. nat. Sci. Philadelphia, 59: 195-207, 2 pls.

Mori, K., W. Sato, T. Nomura \& M. Imajima. 1985. Infestation of the Japanese scallop Patinopecten yessoensis by the boring polychaetes, Polydora, on the Okhotsk Sea coast of Hokkaido, especially in Abashiri waters. Bull. Japan. Soc. sci. Fish., 51(3): 371-380, 11 figs., 3 tbls. (In Japanese with English summary).

Myohara, M. 1979. Reproduction and development of Pseudopolydora kempi jabonica (Polychaeta: Spionidae), with special reference to the polar lobe formation. J. Fac. Sci. Hokkaido Univ., Ser. VI, Zool., 21(4): 355-364, 3 figs., 1 tbl., 2 pls.

- 1980. Reproduction and development of Pieudopolydora paucibranchiata (Polychaeta: Spionidae) under laboratory conditions, with special regard to the polar lobe formation. J. Fac. Sci. Hokkaido Univ., Ser.VI, Zool., 22(2): 145-155, 2 figs., 1 tbl., 3 pls.

Oersted, A.S. 1843. Annularoum danicorum conspectus, 1. Maricolac, 52 pp., 7 pls.

Okuda, S. 1937. Spioniform polychaetes from Japan. J. Fac. Sci. Hokkaido Imp. Univ., Ser. VI, Zool., 5(3): 217-254, 27 figs.

Pettibone, M. 1967. Type-specimens of polychaetes described by Edith and Cyril Berkeley (19231964). Proc. U.S. natn. Mus., 119(3553): 1-23.

Radashevsky, V.I. 1983. Reproduction and larval development of the polychaete Psendopolydora paucibranchiata (Spionidae) in Peter the Great Bay of the Sea of Japan. Mar. Biol., Vladivostok, 2: 38-46, 2 figs. (In Russian with English summary).

. 1985. The larval development of the polychaete Pseudopolydora kempi japonica in Peter the Great Bay of the Sea of Japan. Mar. Biol., Vladivostok, 2: 39-46, 3 figs., 1 pl. (In Russian wich English summary).

. 1986. Reproduction and larval development of the polychaete Polydora ciliata in Peter the Great Bay of the Sea of Japan. Mar. Biol., Vladivostok, 6: 36-43, 3 figs. (In Russian with English summary).

- 1988. Morphology, ecology, reproduction and larval development of Polydora uschakovi (PoJychaeta, Spionidae) in the Peter the Great Bay of the Sea of Japan. Zool. Zh., 67 (6): 870878, 4 figs. (In Russian with English summary).

Ramberg, J.P. \& T.A. Schram, 1982. A systematic review of the Oslofjord species of Polydora Bosc and Pseudopolydora Czerniavsky, with some new biological and ecological data (Polychaeta: Spionidae). Sarsia, 68(4): 233-247, 8 figs., 1 tbl.

Rasmussen, E. 1973. Systematics and ecology of the Isefjord marine fauna (Denmark). Ophelia, 11(1-2): 1-495, 119 figs., 33 tbls.

Read, J.B. 1975. Systematics and biology of polydorid species (Polychaeta: Spionidae) from Wellington Harbour. J.R. Soc. N.Z., 5(4): 395-419, 7 figs.

Rioja, E. 1943. Estudios anelidologicos. VIII. Datos acerca de las especies del genero Polydora Bosc de las costas Mexicanas del Pacifico. An. Inst. Biol. Mexico, 14(1): 229-241, 25 figs.

-1960. Estudios anelidologicos. XXIV. Adiciones a la fauna de anelidos poliquestos de las 
costas orientales de Mexico. An. Inst. Biol. Mexico, 31(1-2): 289-316, 39 figs.

Rzhavsky, A.V., \& E.V. Solokhina. 1988. Polychaetes of Avacha Inlet and their distribution pattern. Mar. Biol., Vladivostok, 5: 65-67. (In Russian with English summary).

__ \& 1989. Polychaetes of Avacha Inlet: benthos, fouling, plankton. In: O.G. Kussakin (ed.), Hydrobiological researches in Avacha Inlet. 39-49, 100-104 (list of species), 4 figs., 3 tbls. (In Russian).

Sato-Okoshi, W., Y. Sugawara \& T. Nomura. 1990. Reproduction of the boring polychaete Polydora variegata inhabiting scallops in Abashiri Bay, North Japan. Mar. Biol., 104(1): 61-66, 7 figs., 2 tbls.

Sirenko, B.I., G.N. Buzhinskaja, V.I. Gontar \& V.V. Potin. 1988. To the fauna of Chikhachev Bay (Sea of Japan). In: A.I. Kafanov (ed.), Biota and communities of the Far Eastern Seas. Lagoons and bays of Kamchatka and Sakhalin. 31-45, 46-48 (list of species), 8 figs. (In Russian).

Slastnikov, G.S. 1957. Polychaete fauna of Onezhsky Bay, the White Sea. Materialy po kompleksnomu izuchenịju Belogo morya, 1: 411-427, 3 figs., 1 tbl. (In Russian).

Söderström, A. 1920. Studien über die Polychaeten familie Spionidae. Inaug. Dissertation, 286 pp., 174 figs., 1 pl. Almquist \& Wicksells, Uppsala.

Southern, R. 1921. Fauna of Chilka Lake. Polychaeta of the Chilka Lake and also of fresh and brackish waters in other parts of India. Mem. Indian Mus., 5: 563-659.

Spassky, N.N. 1961. The intertidal zone of the south-eastern shore of Kamchatka. Explor. Far East. Seas USSR, 7: 261-311, 8 tbls. (In Russian).

Takahashi, K. 1937. Notes on the polychaetous annelid, Polydora pacifica n. sp., which bores holes in Pinctada margaritifera (Linné). Palao trop. biol. Stn. Stud., 2: 155-167, 9 figs., 5 tbls.

Tarakanova, T.F. 1974. The quantitative distribution of polychaetes from the intertidal zone of the Kurile Islands. In: A.V. Zhirmunsky (ed.), Flora and fauna of the intertidal zone of the Kurile Islands, Nauka Press, Novosibirsk. 111-127, 1 fig. (In Russian with English summary).

—_ 1975. Fauna and ecology of the polychaetes in the intertidal zone of the Urup Island (Kurile Islands). Mar. Biol., Vladivostok, 4: 36-45, 2 figs. (In Russian with English summary).

- 1978. The intertidal polychaetes of the east Kamchatka and the Olyutorski Bay. In: O.G. Kussakin (ed.), The intertidal zone of the Bering Sea and south-eastern Kamchatka, Nauka Press, Moscow. 85 97, 3 tbls. (In Russian with English summary).

Tzetlin, A.B., I.A. Zhirkov \& N.P. Markelova. 1983. Polychaeta of the White Sea (Spiomorpha, Drilomorpha, Terebellomorpha). Arch. Zool. Mus. Mosc. St. Univ., 20: 166-186, 8 figs. (In Russian).

Uschakov, P.V. 1950. Polychaeta of the Okhotsk Sea. Explor. Far East. Seas USSR, 2: 140-237, 39 figs., 5 tbis., 2 maps. (In Russian).

_- 1953. The fauna of the Okhotsk Sea and its existence conditions. Izd. Acad. Nauk SSSR, Moscow-Leningrad, 459 pp. with figures. (In Russian).

1955. Polychaeta of the Far Eastein Seas of the USSR. Keys to the fauna of the USSR, 56: 1-445, 164 figs. (In Russian).

- 1959. Polychaeta. A list of the fauna of the sea waters of the South Sakhalin and South Kurile Islands. Explor. Far East. Seas USSR, 6: 201-208. (In Russian).

1965. Polychaeta of the Far Eastern Seas of the USSR. English edition of the $1955 \mathrm{pu}-$ blication. Translated by the Israel Program for Scientific Translations, United States Department of Commerce, Washington, D.C., 419 pp., 164 figs.

- \& B.L. Wu. 1963. Preliminary report on the zoogeography of polychaetous worms (Polychaeta) from the Yellow Sea. Oceanol. Limnol. Sinica, 5(2): 154-164. (In Chinese with Russian summary).

Verrill, A.E. 1880. Notice on recent additions to the marine Invertebrata, of the northeastern coast of America, with descriptions of new genera and species and critical remarks on others. Part II. Annelida, Gephyrea, Nemertina, Nematoda, Polyzoa, Tunicata, Echinodermata, Porifera. Proc. U.S. natn. Mus., 2: 165--205.

Webster, H.E. 1879. The Annelida Chactopoda of the Virginian coast. Trans. Albany Inst., 9: 202 269, 11 pls.

Woodwick, K.H. 1963. Taxonomic revision of two polydorid species (Annelida, Polychaeta, Spioni- 
dae). Proc. biol. Soc. Wash., 76: 209-215, 2 figs.

. 1964. Polydora and related genera (Annelida, Polychaeta) from Eniwetok, Majuro, and Bikini Atolls, Marshall Islands, Pac. Sci., 18: 146-159.

Wu, B.L. \& C. Mu. 1980. Morphology, ecology, reproduction and larval development of Pseudopolydora paucibranchiata (Okuda). Acta Zool. Sinica, 26(4): 356-364, 6 figs. (In Chinese with English summary).

Zachs, I.G. 1933. Polychaeta of the North-Japanese Sea. Explor. Seas USSR, 19: 125-137. (In Russian with German summary). 